\title{
SEQUÊNCIAS DIDÁTICAS E A INTEGRAÇÃO DE SABERES NA EDUCACGAO DO CAMPO
}

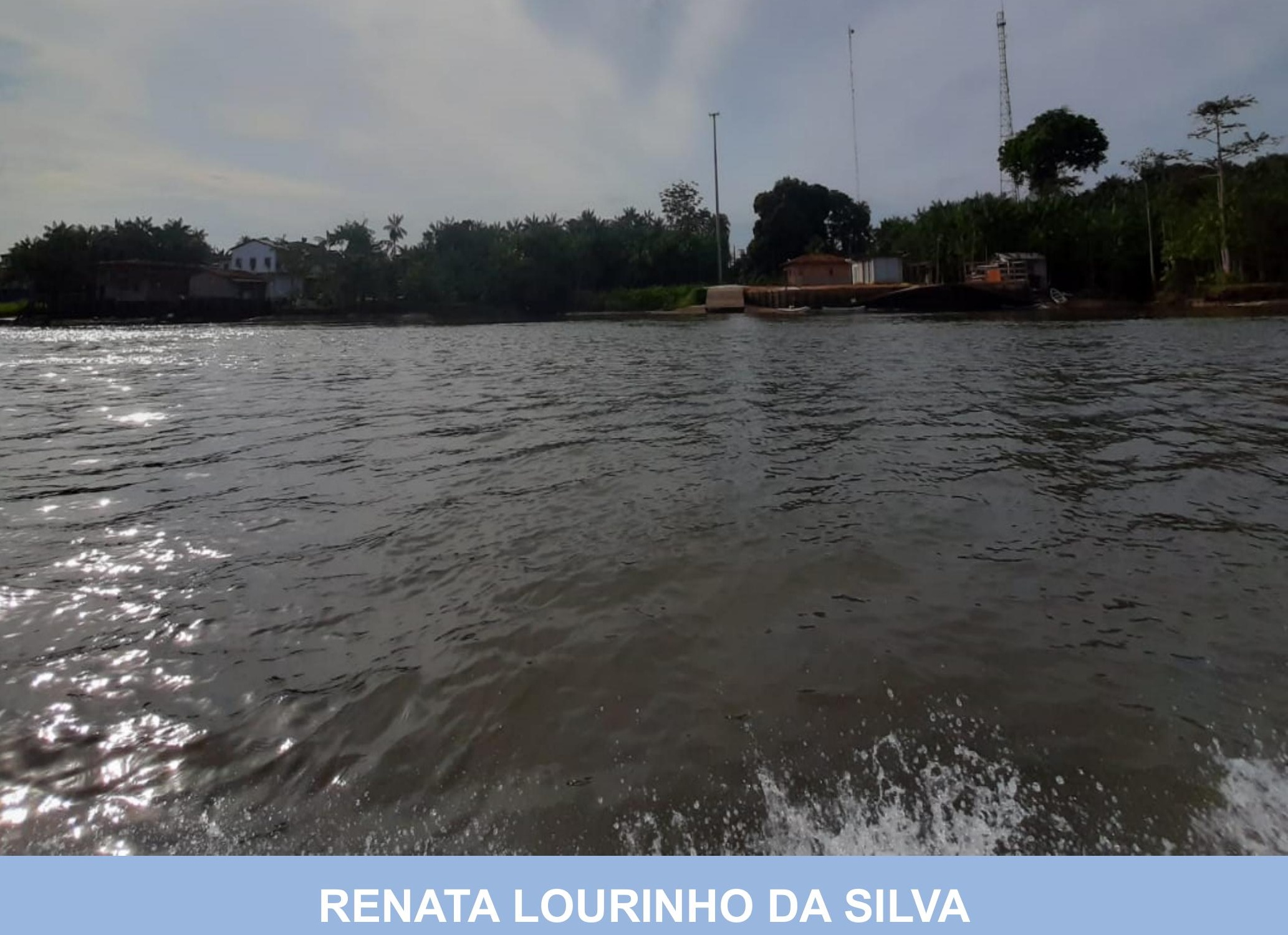

$A \times<0$

EDITORESO 


\section{SEQUÊNCIAS DIDÁTICAS E A INTEGRAÇÃO DE SABERES NA EDUCACGAO DO CAMPO}

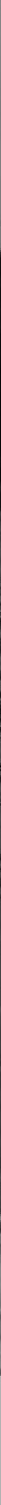

$A \bar{R} C 0$

EDITORES 


\section{CONSELHO EDITORIAL}

Prof. Dr. Adilson Tadeu Basquerot e Silva

UNIDAVI/SC

http://lattes.cnpq.br/8318350738705473

Profa. Msc. Jesica Wendy Beltrán

UFCE- Colômbia

http://lattes.cnpq.br/0048679279914457

Profa. Dra Fabiane dos Santos Ramos UFSM- Santa Maria/RS

http://lattes.cnpq.br/0003382878348789

Dr. João Riél Manuel Nunes Vieira de

Oliveira Brito

UAL - Lisboa- Portugal.

http://lattes.cnpq.br/1347367542944960

Profa. Dra. Alessandra Regina Müller Germani

UFFS- Passo Fundo/RS

http://lattes.cnpq.br/7956662371295912

Prof. Dr. Everton Bandeira Martins

UFFS - Chapecó/SC

http://lattes.cnpq.br/9818548065077031

Prof. Dr. Erick Kader Callegaro Corrêa UFN- Santa Maria/RS

http://lattes.cnpq.br/2363988112549627

Prof. Dr. Pedro Henrique Witchs

UFES - Vitória/ES

http://lattes.cnpq.br/3913436849859138

Prof. Dr.Thiago Ribeiro Rafagnin UFOB

http://lattes.cnpq.br/3377502960363268
Prof. Dr. Mateus Henrique Köhler UFSM- Santa Maria/RS

http://lattes.cnpq.br/5754140057757003

Profa. Dra. Liziany Müller Medeiros

UFSM- Santa Maria/RS

http://lattes.cnpq.br/1486004582806497

Prof. Dr. Camilo Darsie de Souza

UNISC- Santa Cruz do Sul/RS

http://lattes.cnpq.br/4407126331414

Prof. Dr. Dioni Paulo Pastorio

UFRGS - Porto Alegre/RS

http://lattes.cnpq.br/7823646075456872

Prof. Dr. Leonardo Bigolin Jantsch

UFSM- Palmeira das Missões/RS

http://lattes.cnpq.br/0639803965762459

Prof. Dr. Leandro Antônio dos Santos

UFU- Uberlândia/MG

http://lattes.cnpq.br/4649031713685124

Dr. Rafael Nogueira Furtado

UFJF- Juiz de Fora/MG

http://lattes.cnpq.br/9761786872182217

Profa. Dra. Angelita Zimmermann

UFSM- Santa Maria/RS

http://lattes.cnpq.br/7548796037921237

Profa. Dra. Francielle Benini Agne

Tybusch

UFN - Santa Maria/RS

http://lattes.cnpq.br/4400702817251869

Copyright (c) Arco Editora, alguns direitos reservados.

Copyright do texto (C) 2021 os autores e as autoras.

Copyright da edição (c) 2021 Arco Editora. 
Diagramação e Projeto Gráfico : Gabriel Eldereti Machado imagem capa: Renata Lourinho da Silva

Revisão: dos/as autores/as.

Dados Internacionais de Catalogação na Publicação (CIP) (Câmara Brasileira do Livro, SP, Brasil)

Silva, Renata Lourinho da
Sequências didáticas e a integração de saberes
na educação do campo [livro eletrônico] / Renata
Lourinho da Silva. -- Santa Maria, RS : Arco
Editores, 2021.
PDF
ISBN 978-65-89949-34-3
1. Educação 2. Educação - Finalidades e objetivos
3. Educação rural 4. Escolas do campo 5. Pedagogia
6rofessores - Formação I. Título.
21-86751 CDD-370.91734

Índices para catálogo sistemático:

1. Educação do campo 370.91734

Maria Alice Ferreira - Bibliotecária - CRB-8/7964

\subsection{9/978-65-89949-34-3}

O padrão linguístico-gramatical, bem como o sistema de citações e referências bibliográficas são prerrogativas de cada autor. Da mesma maneira, o conteúdo e teor de cada capítulo é de inteira e exclusiva responsabilidade de seu respectivo autor. 


\section{SUMÁRIO}

INTRODUÇÃO.

CAPITULO 1

1. ENGENHARIA DIDÁTICA REVERSA ESTUDANDO O MANUAL ORAL DE COMO SE FAZ UM MATAPI

1.1 Manual oral do matapi.......................................................................15

1.2 Manual oral de como se faz um matapi.................................................16

CAPITULO 2

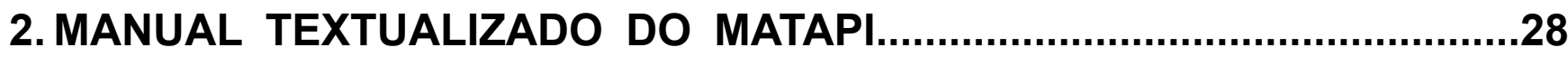

2.1 Manual Textualizado de como se faz um matapi..................................30

2.1.1 Materiais a serem usados na construção............................................30

2.2 Introdução do manual.......................................................................31

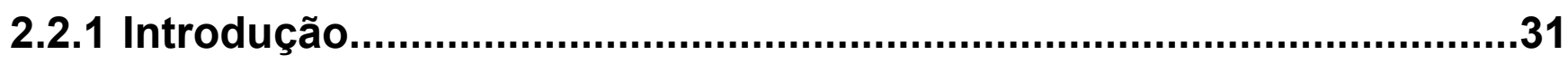

2.3 Passos para a construção do matapi.....................................................31

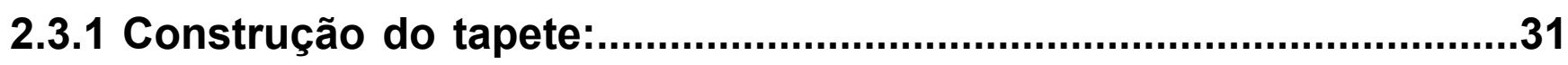

2.3.2 Etapas da construção do pari- tapete: ..................................................32

2.3.3 Etapa: Construção da Língua:................................................................35

2.3.4 Etapa da construção da janela................................................................37

2.4 Medidas para a construção do matapi - geogebra formato tambor...38

2.4.1 Construção do tapete (medidas) ............................................................38

2.4.2 Construção da língua.........................................................................39

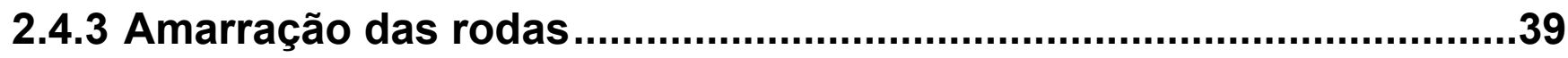

2.4.4 Construção da janela do matapi ..........................................................39 
2.5.1 Construção do tapete

2.5.2 Construção da língua

2.5.3 Construção da porta 40

2.5.4 Problema inicial: Q0 .41

2.6 Atividades interdisciplinares envolvendo o matapi. .44

CAPÍTULO 3. 53

3. Engenharia didática reversa estudando manipulação do conjunto de potência e áras .53

3.1 Tarefa envolvendo o uso do papel chamex, eva e papelão. 54

3.1.1 Execução da nova tarefa a partir da $Q$ 56

3.1.2 Execução da nova tarefa a partir da questão $Q$ 59

3.2 EDR estudando as caixas de papelões como as de perfumes, sabonetes .63

4 ALGUMAS CONSIDERAÇÕES .71

REFERÊNCIAS .72

SOBRE A AUTORA. . .74 


\section{INTRODUÇÃO}

Neste livro apresentam-se algumas sugestões de tarefas para serem utilizadas pelos professores, que lecionam nas escolas localizadas no campo, não somente a eles, mas também se estende aos sistemas de ensino urbano, desde que tenham interesse pelo assunto abordado. Às tarefas elaboradas integram saberes culturais do campo ao nível local e global, aprendidos pela oralidade e imitação (BOURDIEU, 2002), mas não ensinadas (CHEVALLARD, 1999), transformando-os em saberes a ensinar nas escolas desse campo. Podem ser trabaIhadas na educação infantil, anos iniciais e finais do fundamental, ensino médio e superior.

Nesse sentido, tomamos como referência Chevallard (1999, 2009 a 200b,2009c), Chevallard (2013) acerca da transposição didática do saber, a Teoria Antropológica do didático-TAD por meio do recurso teórico-metodológico da engenharia didática de $2 .^{\circ}$ geração, denominado Percurso de Estudos e Pesquisa-PEP.

Nesta coletânea utiliza-se a Engenharia didática reversa- EDR, inspirada na engenharia reversa, que segundo Farias (2009, p. 1): "Trata-se do estudo de um objeto, seja um processador, um monitor, um programa ou até mesmo um simples relógio, desmontando-o e analisando suas peças, seus componentes, seus comandos e seu comportamento (no caso de programas)" e, além disso, a EDR herda as características genéticas do Percurso de Estudos e Pesquisa -PEP, que emerge dos pressupostos da teoria antropológico do didático- TAD, daqui em diante.

Nesse sentido, a EDR é tomada como um Percurso de Estudos e Pesquisa PEP especifico para formação de professores para o campo (SILVA, 2019), estudando as práticas desse campo, a partir do processo de desmonte, procurando entender como elas funcionam, buscando com isso, se possível aprimora-las através da reconstrução, visto que as práticas são aprendidas, mas não ensina- 
das, então, faz-se necessário questioná-la e problematizá-la, de modo que permitam construir processos de transposição didática do saber, para assim, serem ensinadas na escola. (CHEVALLARD, 2009 a), reconstruindo-as.

Nesse sentido, considerando as ideias dos autores supramencionados e da Base Comum Curricular BNCC (2018) acerca da necessidade em trabalhar com as práticas cotidianas. Dessa maneira, elaboraram-se algumas tarefas usando o manual de como se faz um matapi oral e textualizado, poemas do matapi, que estão em minha tese doutoral, bem como, utilizou-se a manipulação de caixas de embalagens diversas, materiais como: eve-a, cartolina, papelão.

Portanto, as características das tarefas elaboradas, estão no fato de que elas partem das práticas sociais ao nível local e global, para assim, ser transformadas em um saber a ser ensinado na escola, por exemplo, as práticas do campo, como é o caso do matapi (SILVA, 2019; SILVA E GUERRA, 2020 a, 2020b, 2021) tem suas origens nas culturais globais como a dos indígenas (LANA, s/d, 2019) sendo aprendidas pela oralidade e imitação, portanto, não são didáticas, mas quando chegam para a escola passam a ser ensinadas, transformando-se em didáticas.

\section{Apresentação dos capítulos}

O capítulo 1 trata sobre as práticas do campo, a partir de um estudo reverso, isto é, tem como ponto de partida os saberes da comunidade do campo, buscando entender como essas práticas são realizadas e pensadas pelo coletivo. Para tanto, faz-se necessário, que se realize a transposição didática dessas práticas (desmonte) para a escola do campo (remonte) (SILVA, 2019).

Esse processo de questionamento e problematização da transposição didática na EDR, possui como uma das características, a de transformação do saber sábio da comunidade do campo(aprendido, não ensinado) em saber a ensinar na escola, permitindo com isso, uma variabilidade de compreensões sobre 
uma determinada prática do campo, por exemplo, a da construção do matapi ${ }^{1}$, que contribui com o entendimento sobre contagem, medidas, figuras planas e espaciais, geometria analítica e esses estudos estão relacionados a outros campos de saberes disciplinares como os da Biologia, busca entender a categoria de comida que o camarão ingere; a cor da água; tamanho de crescimento, que determina ser graúdo e miúdo, a fisiologia, etc.

Geografia acerca do espaço geográfico onde os matapis são colocados que influenciam na sua construção; os materiais usados para a produção, etc.; a História a origem do matapi, sua evolução e modificação ao longo dos tempos; e como essas mudanças influenciaram na natureza, na captura, no desenvolvimento sustentável, etc.; religião sobre questões místicas de como esse instrumento surgiu; o envolvimento dessas questões na construção e uso, como a do "matapi panema"; física sobre os fenômenos relacionados ao movimento de maré baixa e alta; português sobre a variação linguística e suas interpretações culturais da palavra: jequi, camaroeira, língua, boca, panema, e outros.

Além disso, a EDR como uma metodologia de formação de professores, podendo atuar como método de ensino, estuda as práticas do campo (aprendidas, não ensinadas), para então chegar à escola desse campo (ensinada, ou seja, didática) e assim, integrando saberes culturais e escolares.

Também, evidencia-se o matapi, sendo uma prática do campo, geralmente usada para a pesca de camarões e assim elaborou-se tarefas a parti do manual oral de como se faz um matapi, isto é, dos saberes sábios de construção e uso de um dos mestres produtores, da comunidade de Pacuí de cima, município, paraense de Cametá.

No capítulo 2- Explora-se o manual textualizado de como se faz matapis. A partir desse manual, elaborou-se uma sequência didática para trabalhar os conteúdos de matemática na educação infantil, anos iniciais e finais do ensino

1 Matapi- instrumento geralmente utilizado na pesca de camarões, mas pode ter outros fins culturais dependendo do contexto que é usado, bem como o nome linguístico varia em acordo com o lugar, podendo ser denominado de camaroeira, jequi, etc. (SILVA, 2019) 
fundamental, integrando-os ao ensino de história, geografia, português, religião, ciências. E assim, serve como importante material de apoio para o desenvolvimento do ensino em turma multisseriadas, Educação de Jovens e Adultos, Casas famílias rurais.

No capítulo 3- aborda-se tarefas envolvendo outras práticas como as caixas de embalagens diversas e materiais como: eve-a, folha de cartolina, papelão, que também mobilizam a integração de saberes no ensino de matemática e devem ser trabalhadas na educação do campo.

Conclui-se que a EDR percorre campos de saberes distintos, pondo em evidência a integração de saberes no ensino de matemática, por meio da reconstrução criativa e melhorada, em que no primeiro momento, desconstrói-se a prática através de questionamentos e problematizações, isto é, estudam-se as técnicas usadas nelas, procurando entende-las como funcionam e em seguida, reconstruí-las, ou seja, o melhoramento dessas técnicas. 


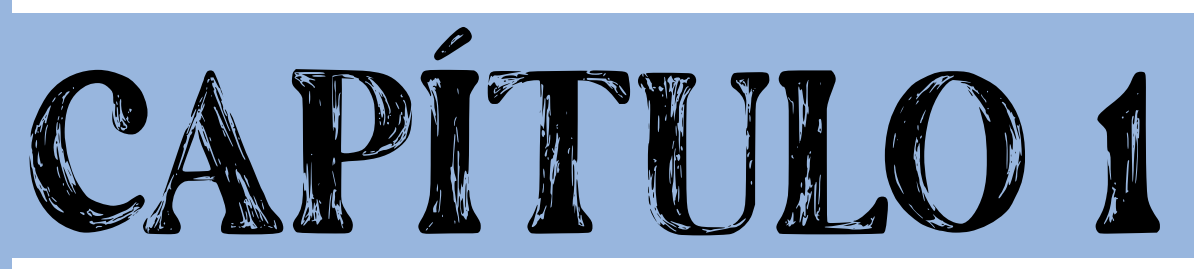

\section{ENGENHARIA DIDÁTICA REVERSA ESTUDANDO 0 MANUAL ORAL DE COMO SE FAZ UM MATAPI}


As práticas sociais estão presentes nas atividades cotidianas, e fazem parte da vida humana desde os primórdios, onde homens e mulheres as usam para a sua sobrevivência e transcendência (D’AMBRÓSIO, 2005, MENDES E FARIAS, 2014).

Nesse sentido, as práticas são os modos de fazer e pensar de um povo e possibilitam o estudo dos problemas cotidianos como a coleta seletiva do lixo, saneamento básico, poluições dos rios, igarapés e outros; nos tecnológicos digitais, atuam no entendimento da robótica, dos celulares, dos computadores, dos 'tablets', etc.; no ambiental, buscam entender como funcionam as atividades de pesca, agricultura, psi cultura, isto é, estão presentes na forma como pensamos e usamos os saberes.

Portanto, devido aos diversificados papeis desempenhados pelas práticas sociais tornam-se de suma importância na mobilização de saberes culturais aprendidos pela oralidade e imitação, que não são ensinados, mas quando questionados e problematizados, transformam-se em saberes a ensinar pelo processo da transposição didática.

Nesse contexto, a Teoria Antropológica do didático- TAD, daqui em diante, possui um dispositivo didático que é denominado de Percurso de estudo e Pesquisa, que Yves Chevallard (2009 C) se refere como engenharia didática de segunda geração ou simplesmente PEP, o qual é visto como provedor de percursos de formação inicial e continuada de professores (CHEVALLARD, BOSCH e GASCÓN, 1997).

Com isso, a EDR herda as características genéticas do PEP (CHEVALLARD, 2009 c), em que um PEP inclui investigações para encontrar uma resposta desejada $R$ para uma questão $(Q)$ de interesse institucional ou pessoal para atender uma dada intencionalidade(ensino), nesse caso, mais especificamente, uma organização praxeológica ${ }^{2}$ complexa do campo(não didática) em uma organiza-

2 Estudo das práticas e dos saberes por meio das tarefas, técnicas, tecnologia e teoria (CHEVALLARD, 1999) 
ção praxeológica didática do campo(ensinada), a partir do encontro de saberes com saberes das disciplinas escolares tradicionais (português, matemática, ciências, história, geografia, religião, artes, etc.) e integrando com a sinergia das lógicas práticas (SILVA, 2019).

Para investir na EDR, leva-se em conta que a TAD oriente os questionamentos das organizações praxeológicas presentes nos estudos das práticas do campo, para poder compreendê-las e, então, propor possíveis correções a partir da construção de um Modelo Praxeológico de Referência, ou simplesmente MPR, no sentido de uma compreensão embrionária que se desenvolva sob condições institucionais dotadas de racionalidades que deram razões para os estudos com os saberes culturais e escolares, considerando as condições ecológicas ${ }^{3}$ dos disciplinares disponíveis pela escola, de modo a prover novas situações, nem todas é claro, para o encontro com os novos saberes pelo processo da transposição didática do saber (SILVA, 2019).

Assim, ao questionar as práticas do campo como organizações praxeológicas complexas, encaminha-se uma compreensão sobre suas 'práxis', sempre como provisória, que permiti reconstruí-la no sentido da linha investigatória sugerida por Chevallard (2009 b).

Essa compreensão foi denominada, em minha tese doutoral como Modelo de Organização Praxeológica do Campo ou simplesmente MOPC, dado pela construção de um manual textualizado de como se faz um matapi, elaborado pelos professores e mestres produtores de matapi da comunidade de Pacui de cima, e demandou que considerasse que um saber prático cultural somente é evidenciado em situação, pois é "um saber em pré-construção que age segundo uma lógica implícita de um código de conduta, portanto, "é frágil, sem vigor, por depender do contexto de situações que não tolera a variações" (CHEVALLARD, 2009 A, p.107), ou seja, se faz de tal maneira, porque é assim que se constrói ele, já o escolar tolera variação, pois permite compreensões diversificadas de um mesmo problema (SILVA, 2019).

3 Como vive os saberes nas práticas socioculturais 
Para construir essa MOPC, a partir da integração de saberes não escolares e escolares, fez necessário fazer revelar saberes práticos, que funcionam segundo a lógica prática, mas que possam ser "lidos", de algum modo, por meio dos escolares, isto é, pondo-os em funcionamento, pois, assim, pode-se fazê-los ascender a um estatuto teórico, que lhes permiti ser posto em discussão.

Sobre esse pressuposto a construção do MOPC, em minha tese doutoral, por exemplo, iniciou na comunidade de Pacuí de Cima, de modo que se encaminhou questionamentos, que permitiram encontrar, como descrições, por exemplo, a superestrutura ${ }^{4}$ do matapi e com isso questiona-se a infraestrutura ${ }^{5}$ de saberes mobilizados para a consecução dessas 'práxis'.

Por isso, o trabalho com as práticas do campo atua no nível da infraestrutura sobre o superestrutural (CHEVALLARD, 2009 c), pois elas representam a forma de fazer e pensar de uma determinada pessoa ou comunidade, e assim abrem possibilidades para a construção de um Percurso de estudos e pesquisa PEP reverso, que integra saberes culturais e escolares em uma dinâmica de reconstrução de saberes a ser ensinados na escola.

Assim, o caminhar de desconstruções para a reconstruções dessas práticas, inspirado na noção de engenharia reversa ${ }^{6}$, mas com intencionalidade para a integração de saberes não escolares, como os culturais da prática profissional do ribeirinho, por exemplo, atuam no funcionamento dos escolares sobre o ensino de uma dada organização praxeológica para o campo, encaminha a um tipo específico de Percurso de Estudos e pesquisa (PEP) orientado por SODRÉ; GUERRA, 2018, SODRÉ, 2019) chamado de Engenharia didática reversa (EDR) que se "assenta sobre a noção da engenharia didática de segunda geração de-

\footnotetext{
4 Superestrutura- construção e uso do matapi, por exemplo.

5 Infraestrutura-questionamento da prática de construção e uso do matapi, como se pensa e como se faz essa prática, por isso, constitui-se como uma prática sociocultural

6 "Trata-se do estudo de um objeto, seja um processador, um monitor, um programa ou até mesmo um simples relógio, desmontando-o e analisando suas peças, seus componentes, seus comandos e seu comportamento (no caso de programas), e isso é feito para descobrir como ele foi fabricado, como ele pode ser melhorado e que outras funções ele pode realizar" (FARIAS, 2009, p.1)
} 
nominadas de PEP, mas com a especificidade da problemática enfrentada, especificamente de construir uma transposição didática de uma dada atividade de uma comunidade do campo, que é aprendida, mas não é ensinada, para então ser ensinada na escola desse campo"(SILVA, 2019, p.54).

\subsection{Manual oral do matapi}

Como vimos anteriormente, a EDR é tomada como uma metodologia de formação de professores para o campo, e procura entender as práticas desse campo, e partir delas, transforma esse saber aprendido, mas não é ensinado, portanto, não é didático, para ser ensinado na escola, tornando-se didático pelo processo da transposição didática.

A partir daí, o manual oral de como se faz um matapi, partiu dos saberes sábios de um dos produtores de matapi da comunidade de Pacuí de Cima (localidade que serviu como campo de pesquisa de minha tese doutoral) localizada no município de Cametá-PA, Brasil, que ensinou os professores em formação continuada a construí matapis no primeiro momento por meio da oralidade.

Figura 1- Modelo de Matapi construído com talas de jupaty

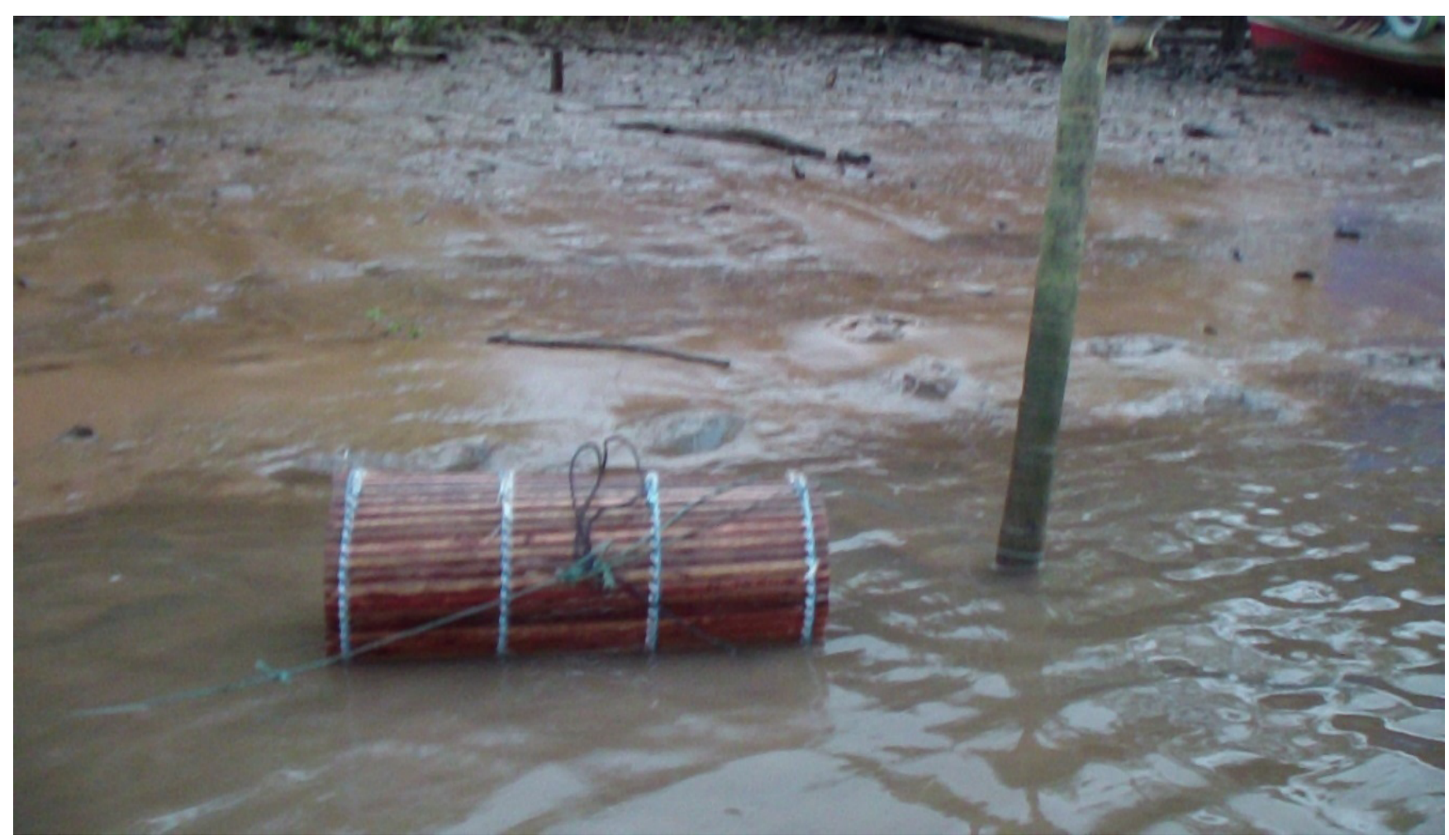

Fonte: Dados da pesquisa (2019) 
Após a construção dos matapis pelos professores, sistematizou-se essa prática, através de questionamentos e problematizações, que resultou na tabela 1 e para finalizar o estudo, construiu-se um novo manual utilizando dados do geogebra, que envolveu os saberes do campo da matemática como noções de distâncias, tronco de cone, raio, diâmetro, etc. do campo da biologia sobre a construção sustentável de matapis a partir do uso de náilon de $4 \mathrm{~mm}$ e $5 \mathrm{~mm}$ (Costa et al., 2016) e de outras disciplinas, que vai ser mostrado nos próximos, secções.

\subsection{Manual oral de como se faz um matapi}

O Manual oral de construção do matapi, vai ao encontro ao que Mendes e Farias (2014) falam sobre as práticas socioculturais como sendo expressões orais das experiências dos povos, repassados de geração a geração, em prol da sobrevivência e transcendência (AMBRÓSIO, 2005).

Relatando um pouco sobre a experiência da construção oral de como se faz um matapi, na formação de professores para o campo, em que os docentes construíram matapis a partir dos ensinamentos de um dos produtores de matapi da comunidade de Pacui, em que ele apresentou os passos e os materiais para tal construção, tais como: talas de jupaty seca7; fio de náilon de $3 \mathrm{~mm}$, para tecer o pari-tapete; cipó de cebola braba ${ }^{8}$ e agrachama ${ }^{9}$, para fazer as rodas interna do matapi; leite de breu ${ }^{10}$, para fazer as rodas internas; leite de breu , para dar maior resistência ao fio quanto ao tecimento da língua; náilon branco, para fazer o "enchuliamento", que serve para costurar as rodas e as línguas no corpo após sua inserção ${ }^{11}$ com auxílio da agulha palheta; náilon $n .^{\circ} 36$, usado para o tecimento

$7 \quad$ As talas de Jupaty seca ocorrem pela exposição ao sol das talas vivas, retirada do gaIho do Jupatizeiro- (Raphia taedigera)" (MORAES, 2005, p.66)

8 Cebola braba- tipo de cipó- nome cientifico: Clusia grandiflora Splitg -Familia: Clusiaceae- (Laudo de Identificação Botânica, Embrapa/Belém, digitado em 14/02/2020)

9 Agrachama - cipó - Nome cientifico: Clytostoma binatum (Thunb). Sandwhite-Familia: Bignoniaceae- (Laudo de Identificação Botânica, Embrapa/Belém, digitado em 14/02/2020)

10 Leite de breu - Extraído do fruto da árvore de Anani, conhecida como "Symphonia globulifera, vulgarmente chamado oanani, guanandi, olandi, anani e ananim, é uma árvore nativa da América Latina e da África tropical. (WIKIPÉDIA, 2020, seção Symphonia globulifera.)

11 Enchuliamento- termo usado pela comunidade de Pacuí de Cima, em que se utiliza o fio de náilon branco com auxílio de uma agulha feita de PVC que tecem as rodas do matapi, bem como, para inserção das línguas. 
da borda circular menor da língua.

Outros materiais usados para a construção da "língua do matapi" : náilon de duas capas, utilizado para o tecimento abaixo da parte central, tem o papel de favorecer maior resistência a amarração; faca para a limpeza das talas, cortar os materiais; alicate, para fazer os cortes da borda circular menor, ajustando-se as pontas das talas; ripa, como medida padrão para a construção do tamanho do matapi; isqueiro, para queimar a ponta do fio de náilon para não desmanchar em contato com água; e pincel, para marcar a divisão de um trançado a outro do pari. A utilização desses materiais reflete os saberes pessoais de José (SILVA, 2019).

Figura 2 - Materiais para construir matapis por meio da oralidade

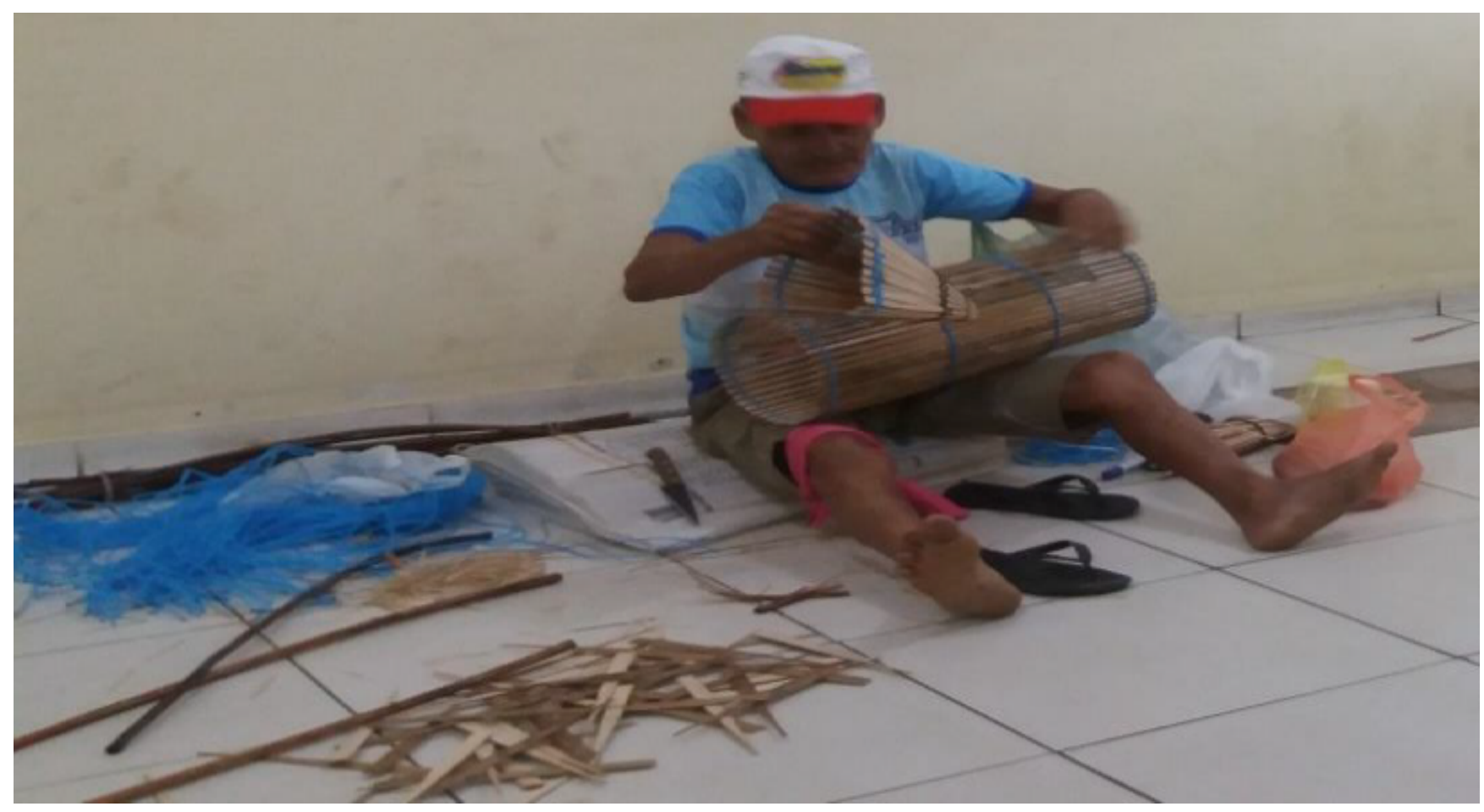

Fonte: Dados da pesquisa (2019)

Os materiais supramencionados foram lidos como um manual oral organizado por José de como se faz um matapi, pois os mesmos não estavam textualizados, mas dotado de uma racionalidade técnica, que explica o seu uso na construção do matapi, logo, é um saber em pré-construção (SILVA, 2019). 
Figura 3 - Professores construindo matapis a parti da oralidade

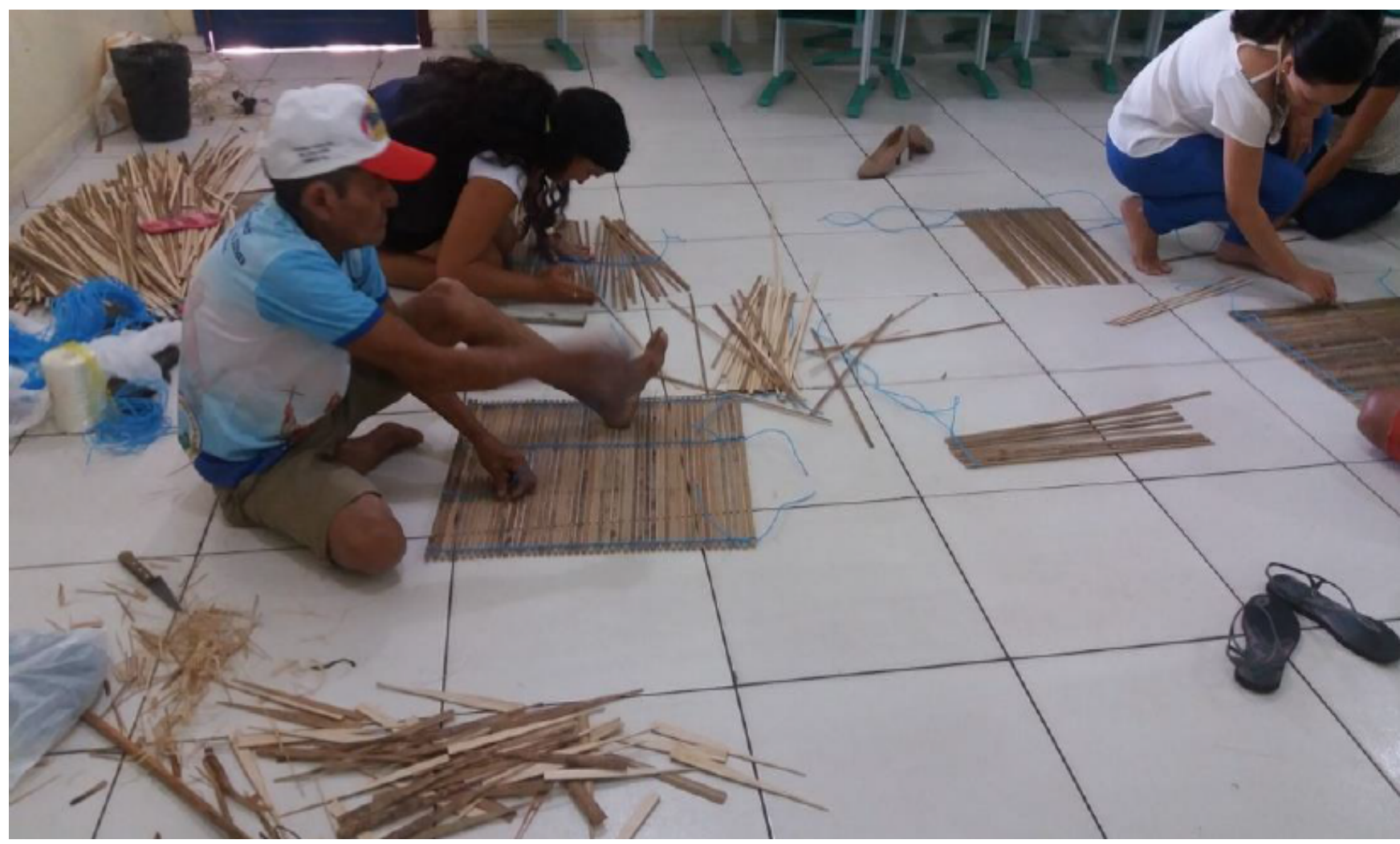

Fonte: Dados da pesquisa (2019)

Após a construção, realizou-se a desconstrução, ou seja, questionamentos e problematizações, que se desencadearam em 7 perguntas-chaves:

$\left.Q_{1}\right)$ Comprimento e altura do matapi?

$\mathrm{Q}_{2}$ ) Diâmetro maior da língua?

$\left.\mathrm{Q}_{3}\right)$ Diâmetro menor da língua?

$\mathrm{Q}_{4}$ ) Distância entre as talas?

$\mathrm{Q}_{5}$ ) Distância entre as línguas?

$\mathrm{Q}_{6}$ ) De que maneira conseguem relacionar a construção e uso do matapi com os saberes da escola?

$\mathrm{Q}_{7}$ ) Como elaborar um manual de construção do matapi.

Os elementos de respostas para as $Q_{1}, Q_{2}, Q_{3}, Q_{4}$ e $Q_{5}$, encaminhados pelos professores, a partir de um modelo de matapi virtual feito por uma 
professora de matemática com ajuda do mestre produtor usando o programa Geo gebra sobre a noção de círculo, de distâncias, diâmetro, altura, comprimento, retas, segmentos, cilindro foram então melhor compreendidos pelas professoras.

Figura 4 - Construção do matapi no geogebra

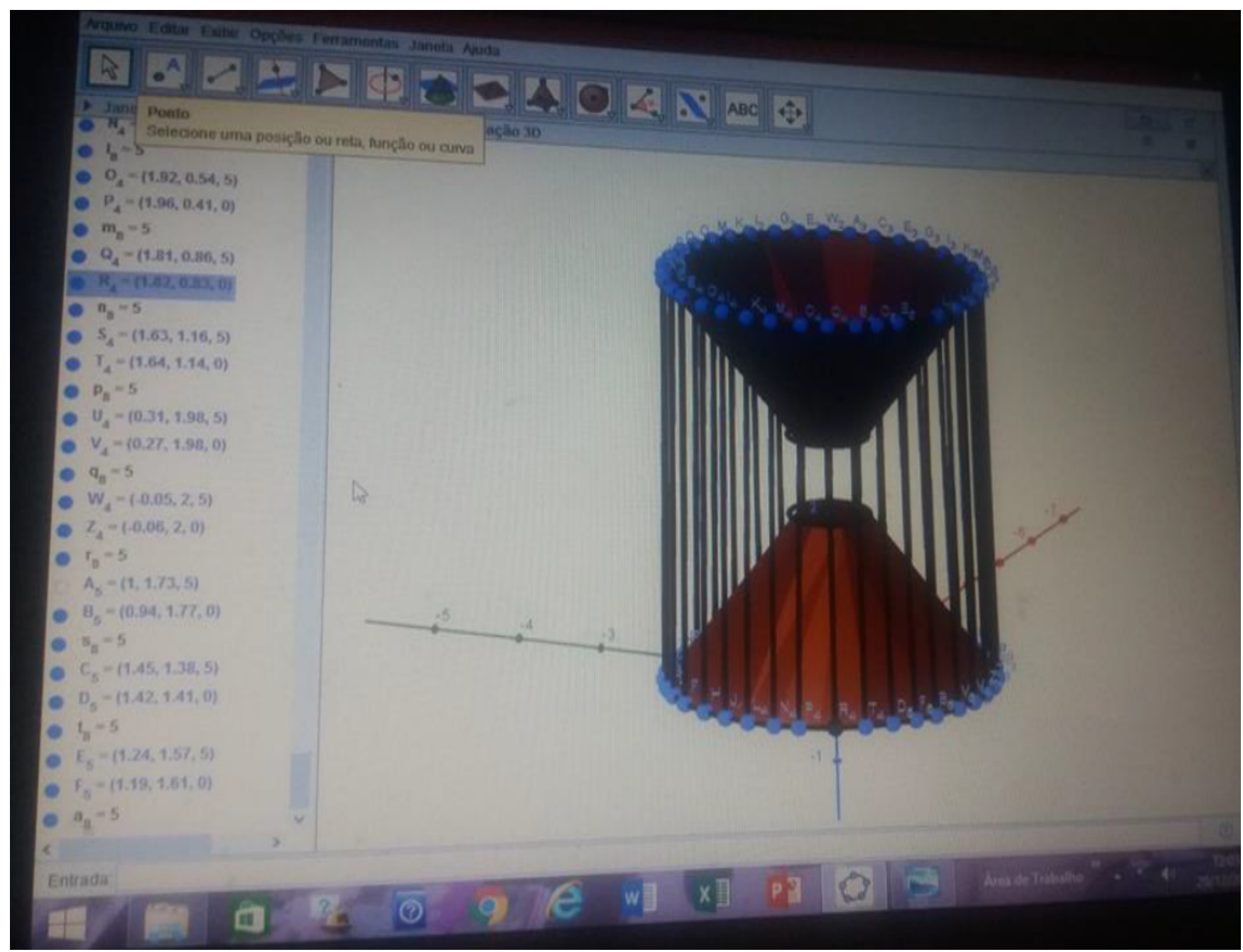

Fonte: Dados da pesquisa (2019) 
Tabela 1 - Respostas quanto as perguntas Q1, Q 2, Q3, Q4, Q 5

\begin{tabular}{|c|c|c|c|c|c|c|c|c|}
\hline \multirow[b]{2}{*}{ MATAPIS } & \multicolumn{4}{|c|}{ Estrutura do Corpo do matapi } & \multicolumn{4}{|c|}{ Língua do matapi- } \\
\hline & $\begin{array}{c}\text { Compri- } \\
\text { mento }\end{array}$ & Altura & $\begin{array}{l}\text { Quant. } \\
\text { Talas } \\
\text { do } \\
\text { tapete }\end{array}$ & $\begin{array}{c}\text { Distância } \\
\text { entre as } \\
\text { talas } \\
\text { (MM) }\end{array}$ & $\begin{array}{c}\text { Quant. } \\
\text { de } \\
\text { talas }\end{array}$ & $\begin{array}{c}\text { Diâmetro } \\
\text { Maior } \\
(\mathrm{CM})\end{array}$ & $\begin{array}{c}\text { Diâmetro } \\
\text { Menor } \\
(\mathrm{CM})\end{array}$ & $\begin{array}{c}\text { Distância } \\
\text { entre as } \\
\text { duas } \\
\text { línguas }\end{array}$ \\
\hline SOFIA ${ }^{12}$ & 64 & 56 & 47 & 3 a 4 & 24 & 20 & 3,0 & 12 \\
\hline JOSEFINA $^{13}$ & 64 & 56 & 43 & 3 a 4 & 23 & 20 & 3,0 & 12 \\
\hline PRISCILA $^{14}$ & 65 & 56 & 44 & 3 a 4 & 23 & 21 & 2,5 & 13 \\
\hline JAQUELINE $^{15}$ & 65 & 56 & 43 & 3 a 4 & 23 & 20 & 3,0 & 12 \\
\hline TATIANE $^{16}$ & 63 & 56 & 43 & 3 a 4 & 22 & 20 & 3,0 & 13 \\
\hline LAURA $^{17}$ & 69 & 56 & 45 & 1,5 a 2 & 22 & 20 & 3,5 & 14 \\
\hline BIATRIZ18 & 66 & 56 & 47 & 3 & 22 & 21 & 2,5 & 11 \\
\hline CARLOS ${ }^{19}$ & 65 & 56 & 44 & 4 & 23 & 20 & 3,0 & 12 \\
\hline JOSÉ & 60 & 56 & 47 & 4 & 22 & 20 & 3,0 & 13 \\
\hline JOSÉ & 60 & 56 & 47 & 4 & 23 & 20 & 3,0 & 13 \\
\hline
\end{tabular}

Fonte: Dados da pesquisa (2019)

$12 \quad$ Nome fictício e corresponde ao gênero

13 Nome fictício e corresponde ao gênero

14 Nome fictício e corresponde ao gênero

15 Nome fictício e corresponde ao gênero

16 Nome fictício e corresponde ao gênero

$17 \quad$ Nome fictício e corresponde ao gênero

18 Nome fictício e corresponde ao gênero

19 Nome fictício e corresponde ao gênero 
A partir da tabela 01, encaminha-se as seguintes tarefas:

Para trabalhar com os conteúdos de Matemática anos iniciais

Complete a tabela 1:

\begin{tabular}{|c|c|c|c|c|c|c|c|c|}
\hline \multirow[b]{2}{*}{ MATAPIS } & \multicolumn{4}{|c|}{ Estrutura do Corpo do matapi } & \multicolumn{4}{|c|}{ Língua do matapi- } \\
\hline & $\begin{array}{c}\text { Compri- } \\
\text { mento }\end{array}$ & Altura & $\begin{array}{c}\text { Quant. } \\
\text { Talas } \\
\text { do } \\
\text { tapete }\end{array}$ & $\begin{array}{c}\text { Distância } \\
\text { entre as } \\
\text { talas } \\
\text { (MM) }\end{array}$ & $\begin{array}{c}\text { Quant. } \\
\text { de } \\
\text { talas }\end{array}$ & $\begin{array}{l}\text { Diâmetro } \\
\text { Maior } \\
(\mathrm{CM})\end{array}$ & $\begin{array}{c}\text { Diâmetro } \\
\text { Menor } \\
(\mathrm{CM})\end{array}$ & $\begin{array}{c}\text { Distância } \\
\text { entre as } \\
\text { duas } \\
\text { línguas }\end{array}$ \\
\hline SOFIA ${ }^{20}$ & 64 & 56 & 47 & 3 a 4 & 24 & 20 & 3,0 & 12 \\
\hline JOSEFINA ${ }^{21}$ & 64 & 56 & 43 & 3 a 4 & 23 & 20 & 3,0 & 12 \\
\hline PRISCILA ${ }^{22}$ & 65 & 56 & 44 & 3 a 4 & 23 & 21 & 2,5 & 13 \\
\hline JAQUELINE $^{23}$ & 65 & 56 & 43 & 3 a 4 & 23 & 20 & 3,0 & 12 \\
\hline TATIANE $^{24}$ & 63 & 56 & 43 & 3 a 4 & 22 & 20 & 3,0 & 13 \\
\hline LAURA $^{25}$ & 69 & 56 & 45 & 1,5 a 2 & 22 & 20 & 3,5 & 14 \\
\hline BIATRIZ26 & 66 & 56 & 47 & 3 & 22 & 21 & 2,5 & 11 \\
\hline CARLOS $^{27}$ & 65 & 56 & 44 & 4 & 23 & 20 & 3,0 & 12 \\
\hline JOSÉ & 60 & 56 & 47 & 4 & 22 & 20 & 3,0 & 13 \\
\hline JOSÉ & 60 & 56 & 47 & 4 & 23 & 20 & 3,0 & 13 \\
\hline Total & & & & & & & & \\
\hline
\end{tabular}

Fonte: Dados da pesquisa (2019)

$20 \quad$ Nome fictício e corresponde ao gênero

$21 \quad$ Nome fictício e corresponde ao gênero

22 Nome fictício e corresponde ao gênero

23 Nome fictício e corresponde ao gênero

$24 \quad$ Nome fictício e corresponde ao gênero

25 Nome fictício e corresponde ao gênero

26 Nome fictício e corresponde ao gênero

$27 \quad$ Nome fictício e corresponde ao gênero 
1) Sobre a estrutura do corpo do matapi:

a) Total de comprimento?

b) Total da altura?

c) Total quantidade de talas do tapete?

2) Sobre a língua do matapi

a) Total de quantidade de talas?

b) Total do diâmetro maior $(\mathrm{CM})$ ?

c) Total diâmetro menor $(\mathrm{CM})$ ?

d) Total das distâncias entre as duas línguas?

3) O que é comprimento?

4) O que é altura?

5) O que é diâmetro?

6) O que é distância?

7) Represente em forma de desenho o comprimento de $64 \mathrm{~cm}$ e altura de $56 \mathrm{~cm}$ ?

8) Represente em forma de gráfico a tabela 01 referente ao comprimento $X$ altura.

9) O que você observa nesse desenho?

10) Represente em forma desenho como pode ser o matapi de Sofia?

11) Represente em forma desenho como pode ser o matapi de Laura?

12) Existem semelhanças entre a estrutura do corpo do matapi de Sofia e Laura? Por que?

13) Existem semelhanças entre a língua do matapi de Sofia e Laura? Por que? 
Para os anos finais pode-se explorar as seguintes questões:

14) O que é média aritmética?

15) Como se calcula?

16) Calcule a média aritmética da estrutura do corpo do matapi, referente ao:

a) Comprimento

b) Altura

c) Quantidade de talas

17) Calcule a média aritmética da língua do matapi, referente a:

a) Quantidade de talas da língua

b) Diâmetro maior $(\mathrm{CM})$

c) Diâmetro menor $(\mathrm{CM})$

d) Distâncias entre as duas línguas

18) O que é moda?

19) Como se calcula?

20) Encontre a moda da estrutura do corpo do matapi, referente ao:

d) Comprimento

e) Altura

f) Quantidade de talas

21) Encontre a moda da língua do matapi, referente a:

e) Quantidade de talas da língua

f) Diâmetro maior $(\mathrm{CM})$

g) Diâmetro menor $(\mathrm{CM})$

h) Distâncias entre as duas línguas 
22) O que é mediana?

23) Como se calcula?

24) Encontre a mediana da estrutura do corpo do matapi, referente ao:

g) Comprimento

h) Altura

i) Quantidade de talas

25) Encontre a mediana da língua do matapi, referente a:

i) Quantidade de talas da língua

j) Diâmetro maior $(\mathrm{CM})$

k) Diâmetro menor (CM)

1) Distâncias entre as duas línguas

26) O que é ponto médio?

27) Como calcular o ponto médio?

28) Encontre o Ponto médio:

\begin{tabular}{|c|c|c|}
\hline & $\begin{array}{c}\text { Distância entre as talas } \\
(\mathbf{M M})\end{array}$ & Ponto médio \\
\hline SOFIA $^{28}$ & $3-4$ & \\
\hline JOSEFINA $^{29}$ & $3-4$ & \\
\hline PRISCILA & $3-4$ & \\
\hline JAQUELINE $^{31}$ & $3-4$ & \\
\hline TATIANE $^{32}$ & $3-4$ & \\
\hline LAURA $^{33}$ & $1,5-2$ & \\
\hline
\end{tabular}

$28 \quad$ Nome fictício e corresponde ao gênero

29 Nome fictício e corresponde ao gênero

30 Nome fictício e corresponde ao gênero

$31 \quad$ Nome fictício e corresponde ao gênero

32 Nome fictício e corresponde ao gênero

33 Nome fictício e corresponde ao gênero 
Para trabalhar ciências (temas de sustentabilidade ambiental)

29) Para que serve o matapi ?

30) A distância entre as talas da estrutura do corpo do matapi influência na captura do camarão? Por que?

31) O que é camarão?

32) Que tipo de comida o camarão come?

33) O matapi é colocado na água? Por quê?

34) Como é feito o matapi?

35) Mostre em forma de desenhos as diferenças e semelhanças entre o matapi Laura e Carlos?

36) Comparando as distâncias entre as talas da estrutura do corpo do matapi de Tatiane, Laura, Beatriz e Carlos? Qual delas é mais sustentável? Por que?

Tabela 2 - Comparando distâncias entre as talas do tapete

\begin{tabular}{|c|c|}
\hline & Distância \\
\hline TATIANE $^{34}$ & 3 a 4 \\
\hline LAURA $^{35}$ & 1,5 a 2 \\
\hline BIATRIZ & 36 \\
\hline CARLOS $^{37}$ & 3 \\
\hline
\end{tabular}

Fonte: Fragmentos da tabela 01

37) O que é sustentabilidade? Como definir?

$34 \quad$ Nome fictício e corresponde ao gênero

$35 \quad$ Nome fictício e corresponde ao gênero

$36 \quad$ Nome fictício e corresponde ao gênero

$37 \quad$ Nome fictício e corresponde ao gênero 
Para trabalhar com língua portuguesa

Observação: As tarefas 32 a 38 podem ser trabalhadas desde os anos iniciais, enquanto a tarefa $32,33,35,38$ podem ser desenvolvidas desde a educação infantil.

38) O que significa a palavra matapi?

39) Quantas letras tem a palavra matapi?

40) O que são letras?

41) Qual o significado da palavra língua?

42) Quantas silabas tem a palavra língua?

43) O que são silabas?

44) O que significa o nome de Tatiane?

45) A palavra matapi e língua é uma figura de linguagem? Se forem, que tipos de figuras são? Por que? (tarefa para anos finais, ensino médio)

46) O que é variação linguística? Como identificar? (tarefa para anos finais, ensino médio)

\section{Para trabalhar com História}

Observação: As questões 33 e 34 podem ser trabalhadas desde os anos iniciais

33) Como se originou o matapi?

34) Conte em forma de desenhos a história do matapi? 


\section{Para trabalhar com geografia}

Observação: As questões 33 e 34 podem ser trabalhadas desde os anos iniciais 35) O matapi vive em que lugares?

36) Mostre em forma de desenhos um lugar onde pode viver o matapi?

Enfim, as questões elaboradas a partir da tabela 1, percorreram campos de saberes diversos, isto é, integrando saberes da cultura de construções de matapis com os da escola, em que se pode observar a matemática sendo trabalhada com ciências, história, geografia, língua portuguesa e assim evidenciando um percurso de estudos e pesquisa reverso-PEP reverso, que encaminhou a construção de uma sequência didática. 


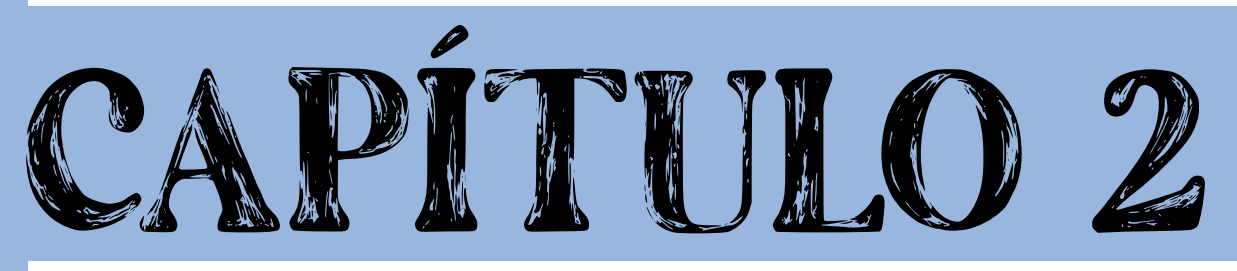

\section{MANUAL TEXTUALIZADO DO MATAPI}


Neste capítulo apresenta-se o manual textualizado de como se faz modelos de matapis, usando a integração de saberes culturais e escolares, em uma dinâmica de reconstrução de saberes, em que o desenvolvimento da EDR encaminhou várias sequências didáticas a partir da construção de quatro modelos de matapis, conforme figura 05.

Figura 5 - Modelos de Matapis

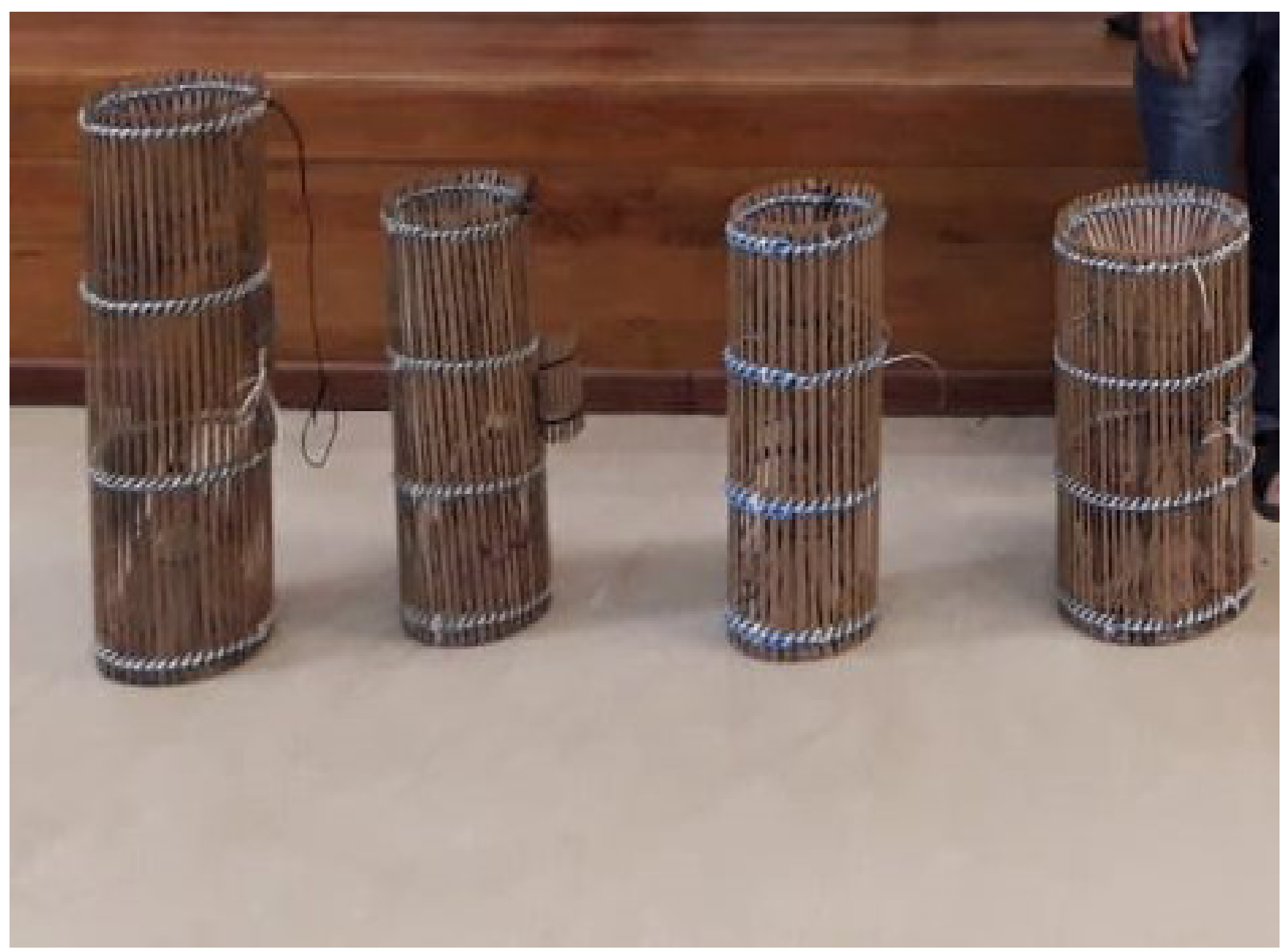

Fonte: Dados da pesquisa (2019)

Segue o manual textualizado de como se faz os modelos de matapis apresentados na figura 05 , em seguida, elaborou-se tarefas para trabalhar com os mesmos em sala de aula. 


\subsection{Manual Textualizado de como se faz um matapi}

\subsubsection{Materiais a serem usados na construção}

$>$ Talas de Jupati seca;

> NAILON $\mathrm{n}^{\circ} 4 \mathrm{~mm}$ e $5 \mathrm{~mm}$ são os mais indicados para a captura de camarões graúdos e médios, podendo

$>$ ser de $3 \mathrm{~mm}$, mas é necessário que se produza uma distância entre as talas a partir de $5 \mathrm{~mm}$ para um manejo adequado do camarão;

$>$ Usar arames de cobre ou alumínio n 18 para a construção da língua, apenas quando for utilizar náilon de $3 \mathrm{~mm}$, se o fio de náilon for $4 \mathrm{~mm}, 5 \mathrm{~mm}$, não precisa, já que o tamanho da grossura possibilita uma boa amarração das talas dessa língua;

> Náilon de 3 ou 2 capas para reforçar o tecimento do fechamento da língua;

> Náilon n 36 e 42 para fechar a borda, que forma o círculo menor da língua, também serve para dividir a língua em duas partes iguais, amarrando-se da parte menor parte a maior. É o processo para não desmanchar a língua para não soltar o tecimento, porque quando entra em contato com a água, ela retira o breu;

> Trena (fita métrica) ou um pedaço de madeira, usada como medida padrão ou, então, risca no assolho. Essa medida determina o tamanho do matapi, por exemplo, se deseja construir um matapi com tamanho de $60 \mathrm{~cm}$;

$>$ Leite de breu para dar firmeza ao náilon de três capas. Para usá-lo, enrola o fio em um dos dedos do pé e em seguida, pega o breu e vai passando;

$>$ Cipó de cebola braba ou agrachama para a construção das rodas;

> Faca, alicate de corte, para fazer o corte do círculo e pare cortar o arame, isqueiro que queima a ponta do náilon, agulha palheta, é feita de plástico como PVC com $5 \mathrm{~cm}$ de comprimento. 


\subsection{Introdução do manual}

\subsubsection{Introdução}

- Ir na floresta coletar a tala e o cipó de cebola braba ou agrachama. Após extrair as talas, deixar uma semana para secar ao sol, depois cortar no tamanho que deseja fazer o matapi;

- Limpe as talas de jupaty, corte na metragem que deseja construir o tamanho do matapi, o mesmo processo se aplica ao cipó;

- Organize todo o material de uso;

- Sente-se no piso ou assoalho da casa e com o apoio do Joelho e do pé inicie a tarefa;

- Corte o fio de náilon de $4 \mathrm{~mm}$, de acordo com o tamanho da largura do matapi, sugere de $2,20 \mathrm{~cm}$ de tamanho, dívida esse fio em duas partes iguais sem fazer corte;

Agora, vejamos os passos da construção do pari-tapete e da língua. Os passos apresentados servem tanto para os matapis da natureza quanto aqueles construídos pelo auxílio do Geogebra, suas diferenças estão com relação à altura e comprimento, quantidade de talas, diâmetro maior e menor da língua, distâncias entre as línguas.

\subsection{Passos para a construção do matapi}

\subsubsection{Construção do tapete:}

$1^{\circ}$ passo:

> Para o matapi da natureza, tecer o tapete em média com 47 talas;

> Usar náilon de $4 \mathrm{~mm}$ ou $5 \mathrm{~mm}$, e pincel atômico para marcar as divisões do tapete. 


\subsubsection{Etapas da construção do pari- tapete:}

\section{$2^{\circ}$ passo:}

$>$ Corte o fio de náilon com tamanho de 2,20cm;

$>$ Agora, pegue esse fio cortado, coloque uma a uma a tala de jupaty, pressionando-a com o pé e com as mãos, levante-a, encaixando o náilon de $4 \mathrm{~mm}$ ou $5 \mathrm{~mm}$, deixando $2 \mathrm{~cm}$ de espaço do primeiro trançado para a ponta da extremidade do tapete;

> Ajuste as talas uma a uma em uma distância entre as talas de $4 \mathrm{~mm}$ ou $5 \mathrm{~mm}$, aperte bem o fio, tecendo o náilon de baixo para cima, de modo que o trançado fique bem ajustado, siga o mesmo processo até o término do tapete, por exemplo, se usar 47 talas, faça esse processo até terminá-la de amarrar, deixe as sobras do náilon livre, pois elas vão servir para fechar o tapete, e repita o processo na outra extremidade do tapete, deixando a sobra do náilon;

Figura 6 - Posição para o tecimento do pari-tapete

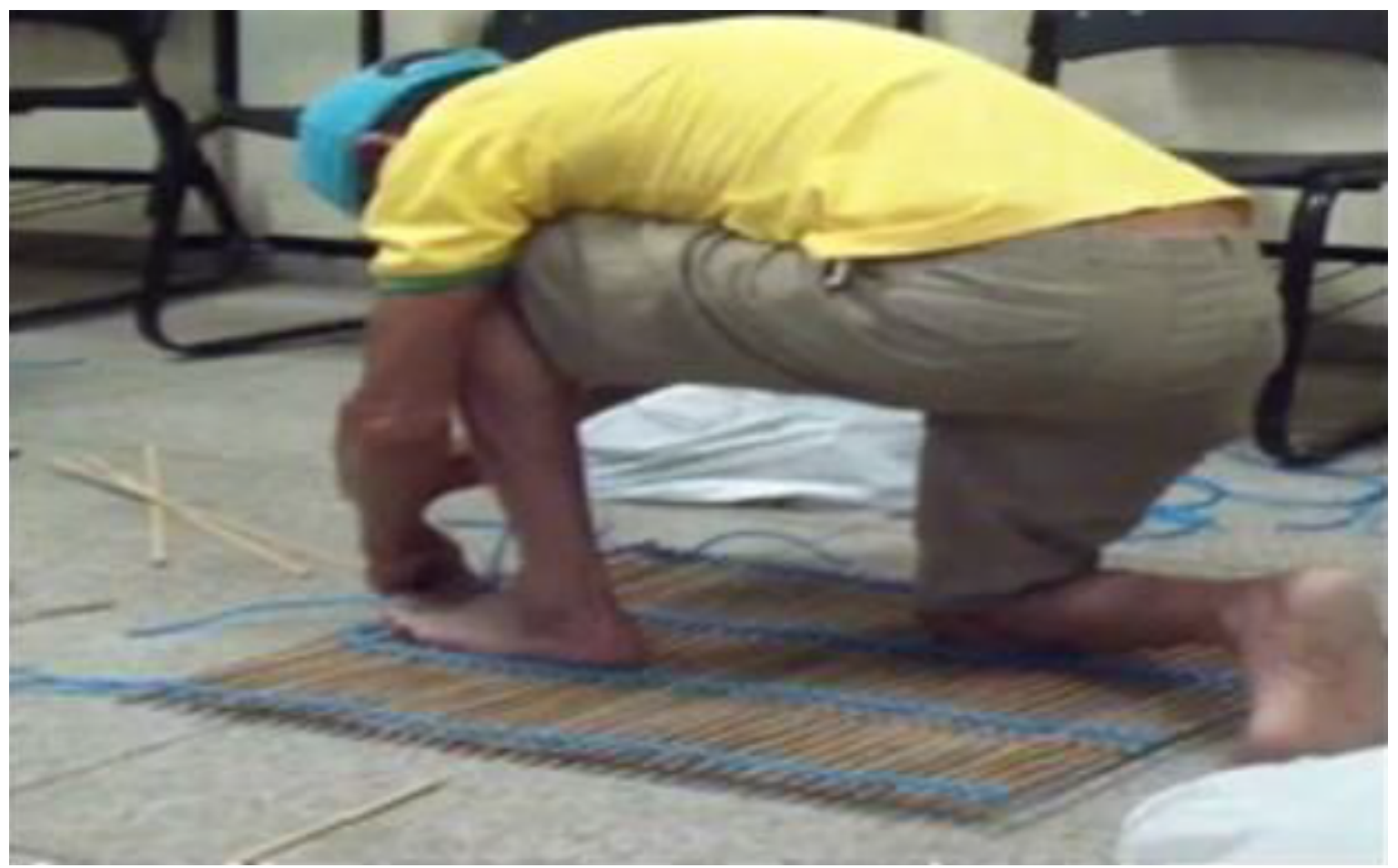

Fonte: Dados da pesquisa (2019)

Observação: Sente-se ao chão, pegue o náilon com as pontas para frente iniciando a tecer as talas. 
Figura 7 - Tecimento nas extremidades do tapete

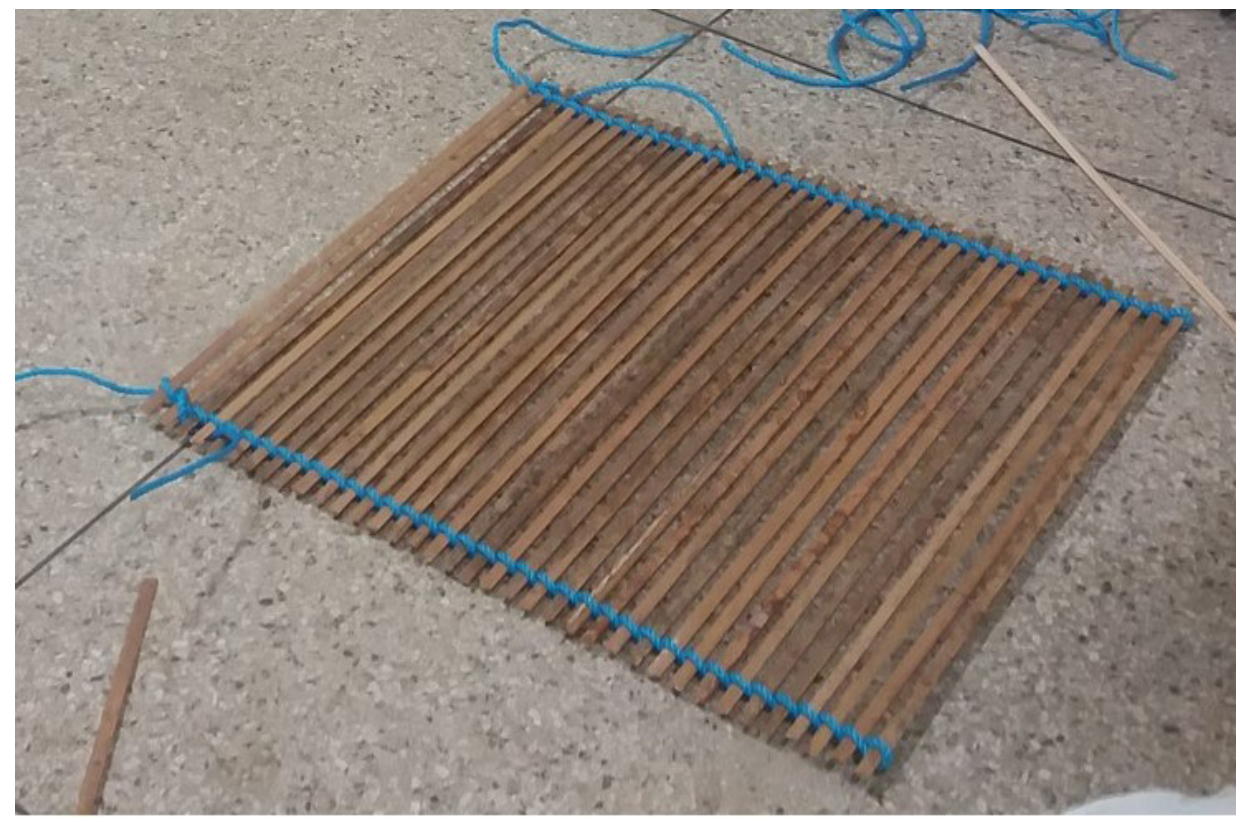

Fonte: Dados da pesquisa (2019)

$>$ Com a ajuda da fita métrica, dívida o tapete em quatro partes iguais, marque as divisões com um pincel, sendo a distância de uma amarração para outra de 07 $\mathrm{cm}$, dependendo do tamanho do matapi. De posse disso, basta tecer o terceiro e quarto trançado, obedecendo ao mesmo processo feito nas extremidades do tapete, deixando a sobra do náilon. Segue imagens abaixo:

Figura 8 - Medida para cada uma das quatro divisões do pari-tapete

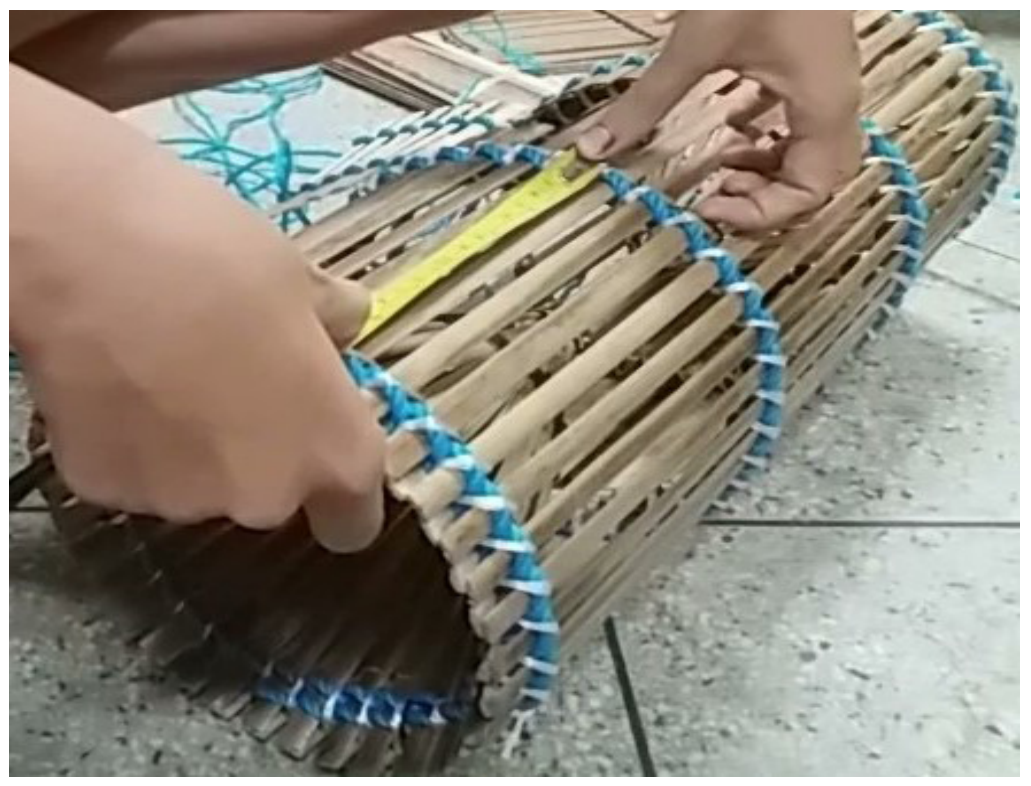

Fonte: Dados da pesquisa (2019) 
Figura 9 - Divisão do tapete em quatro partes iguais

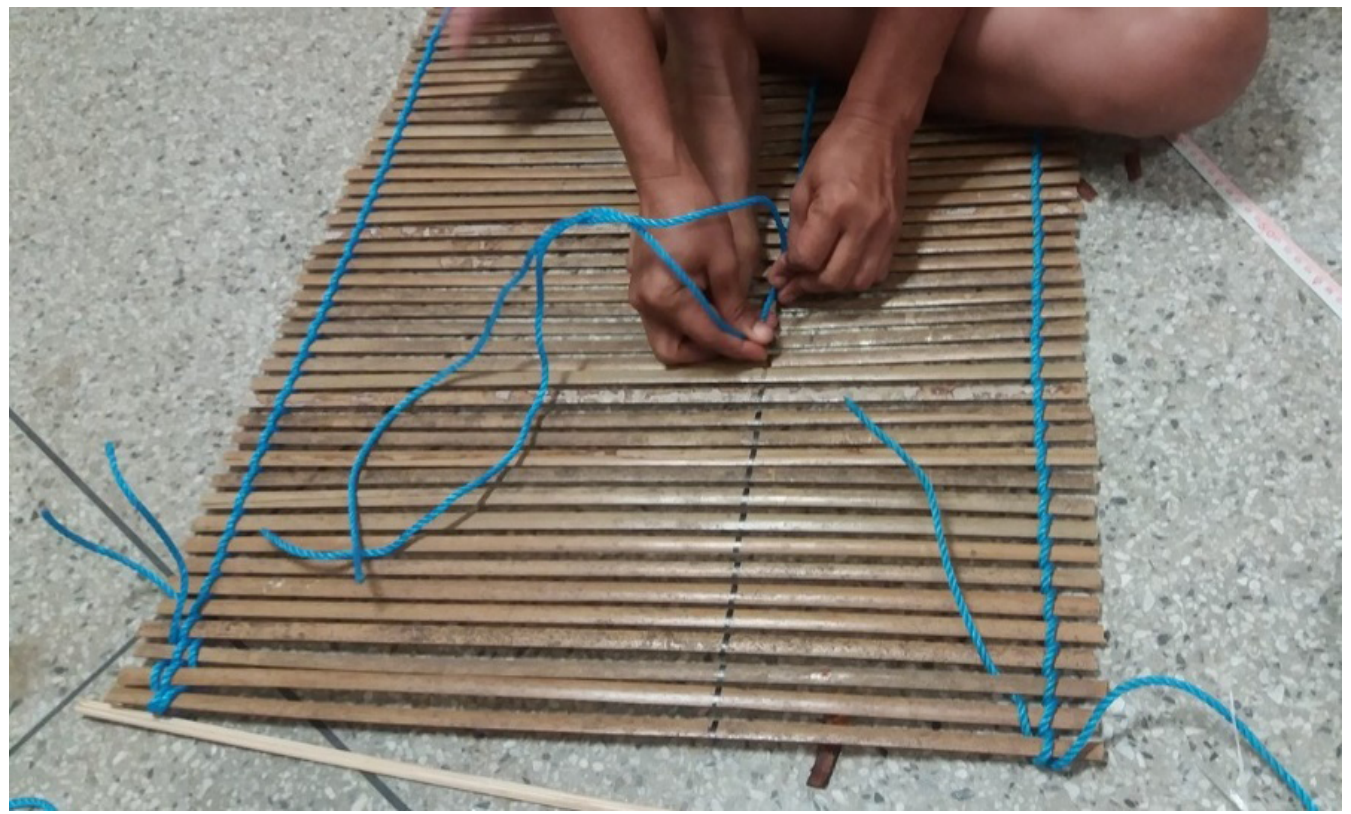

Fonte: Dados da pesquisa (2019)

Finalizado essa primeira etapa de construção do pari- tapete, pegue-o e observe se está tudo correto. Agora, feche o tapete, formando assim o corpo do matapi, que nos lembra a forma de um cilindro. Com isso, pegue as sobras de náilon das quatro amarrações feitas no tapete, uma de cada vez, introduza na mesma direção inicial e amarre-as, fechando assim o tapete.

Figura 10 - Fechamento do tapete formando o corpo do matapi

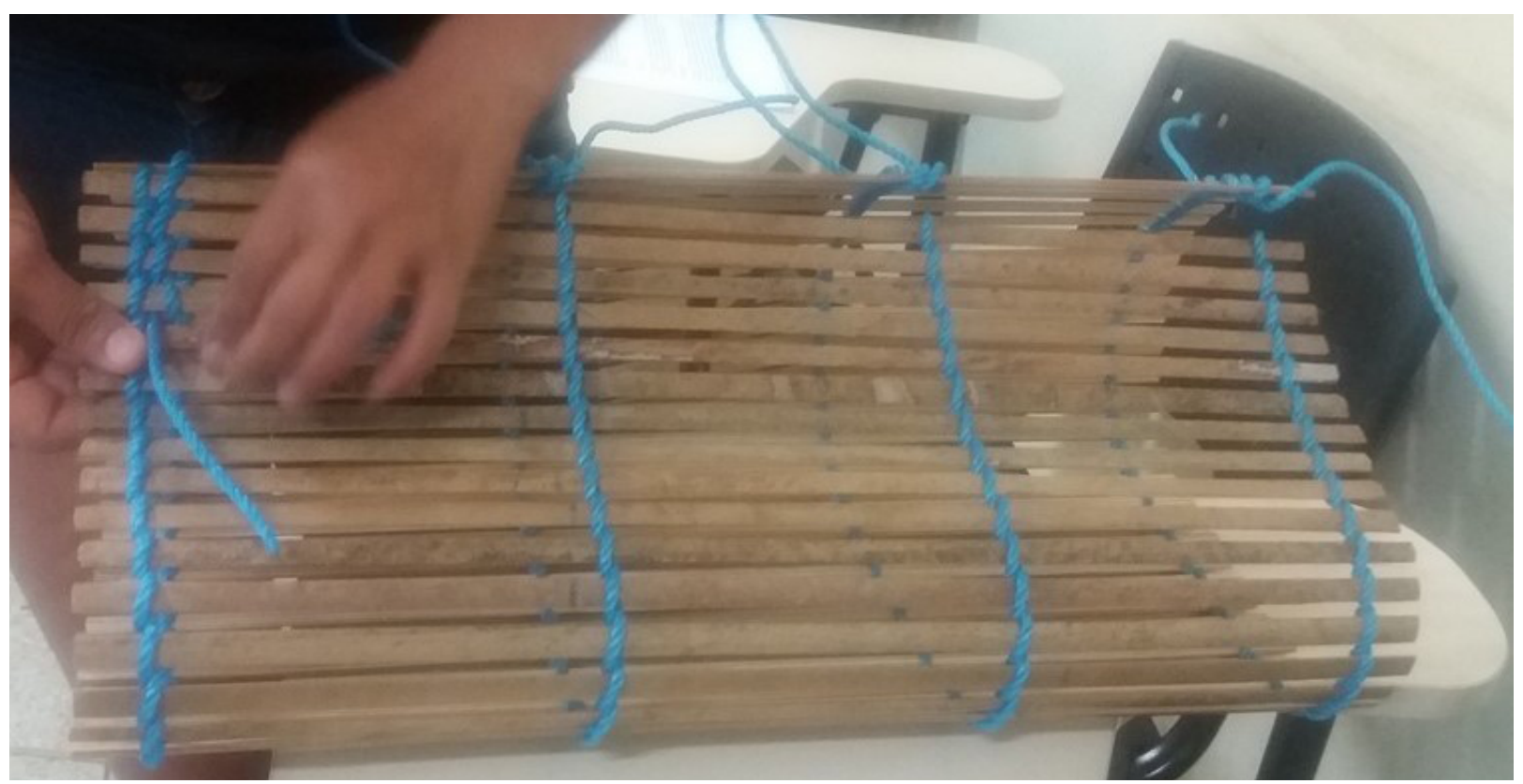

Fonte: Dados da pesquisa (2019) 
$>$ Formado o corpo do matapi, agora insira as rodas feitas de cipó de cebola braba ou agrachama, em cada uma das quatro divisões do tapete, amarrando-as com barbante branco de medida $2 \mathrm{~m}$ para cada roda. Esse fio é colocado entre as distâncias de cada tala, ficando, com isso, por cima do náilon;

Figura 11- Inserção das rodas ao corpo do matapi

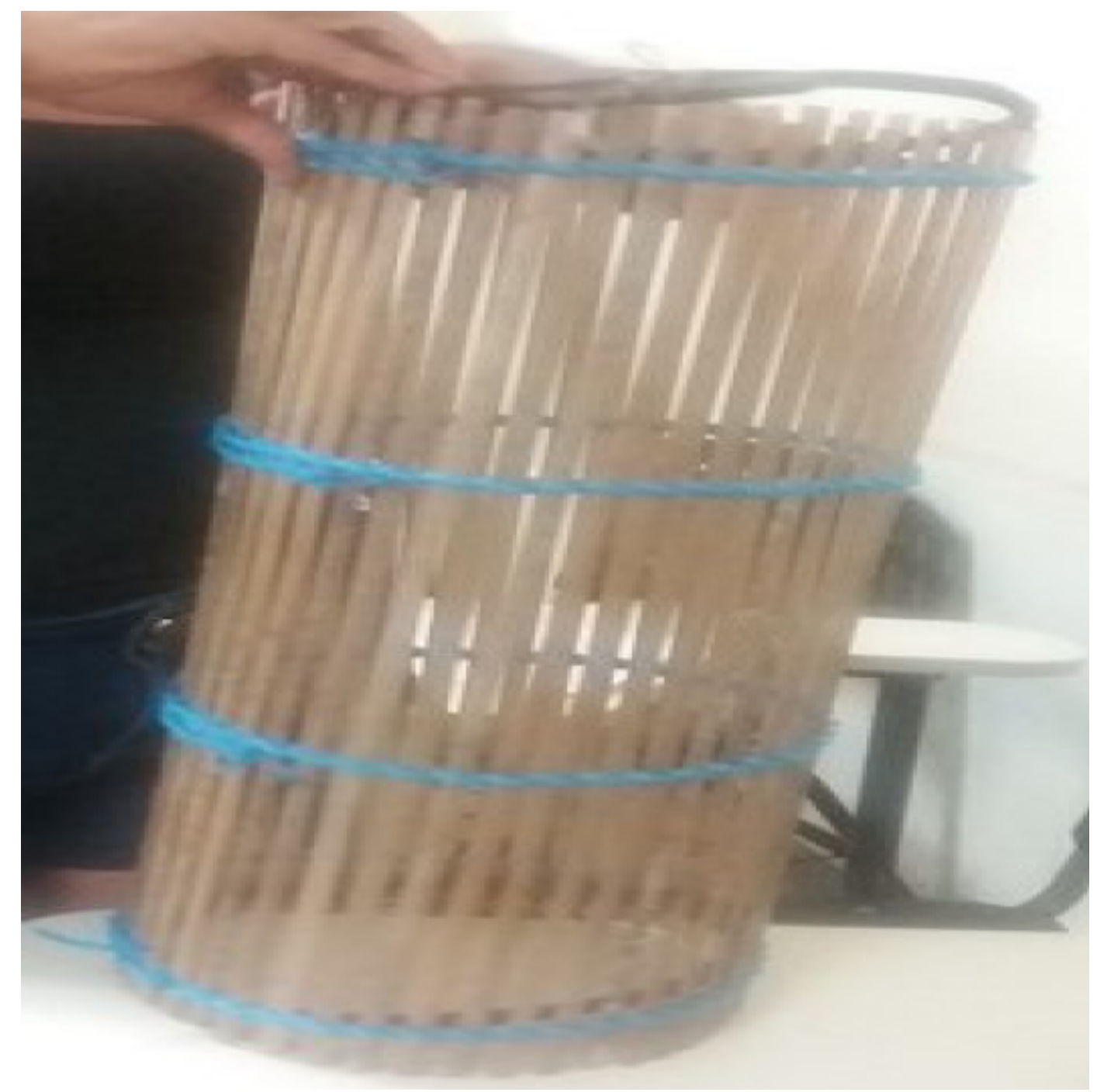

Fonte: Dados da pesquisa (2019)

\subsubsection{Etapa: Construção da Língua:}

$1^{\circ}$ passo: Corte as talas no formato duas em uma.

$2^{\circ}$ passo: Não precisa usar o arame na língua com náilon a partir de $4 \mathrm{~mm}$, em diante, faça o trançado das talas da mesma forma que fez no tapete, inicia-se o trançado pela extremidade da língua, conforme imagem. 
Figura 12 - Construção da língua com náilon de 4mm

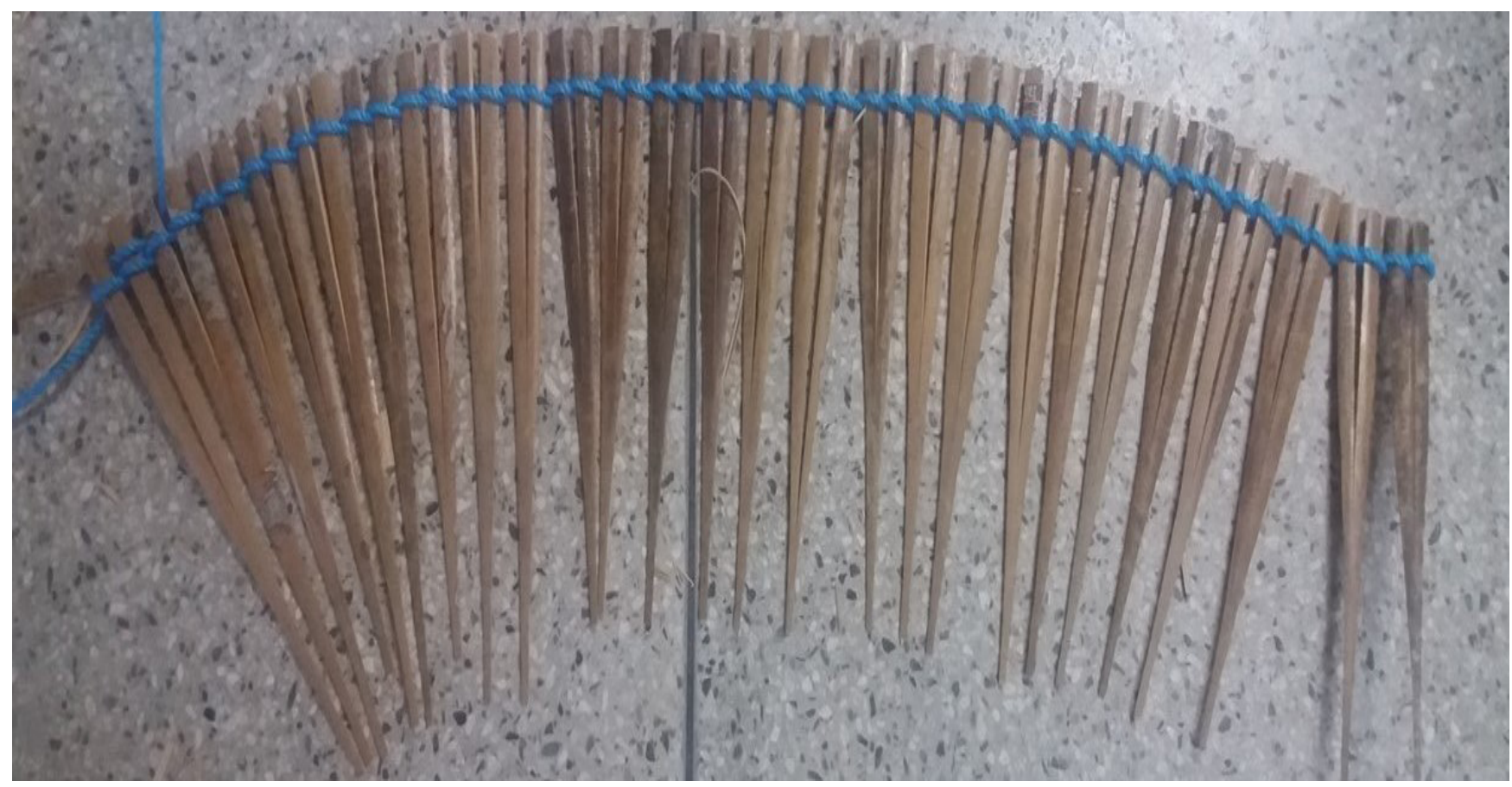

Fonte: Dados da pesquisa (2019)

$3^{\circ}$ passo: Passar o leite de breu no fio de náilon de 3 ou 2 capas, depois é só fazer o trançado desse fio com a tala. Esse trançado irá nos lembrar um leque.

Figura 13 - Náilon preto de 3 capas

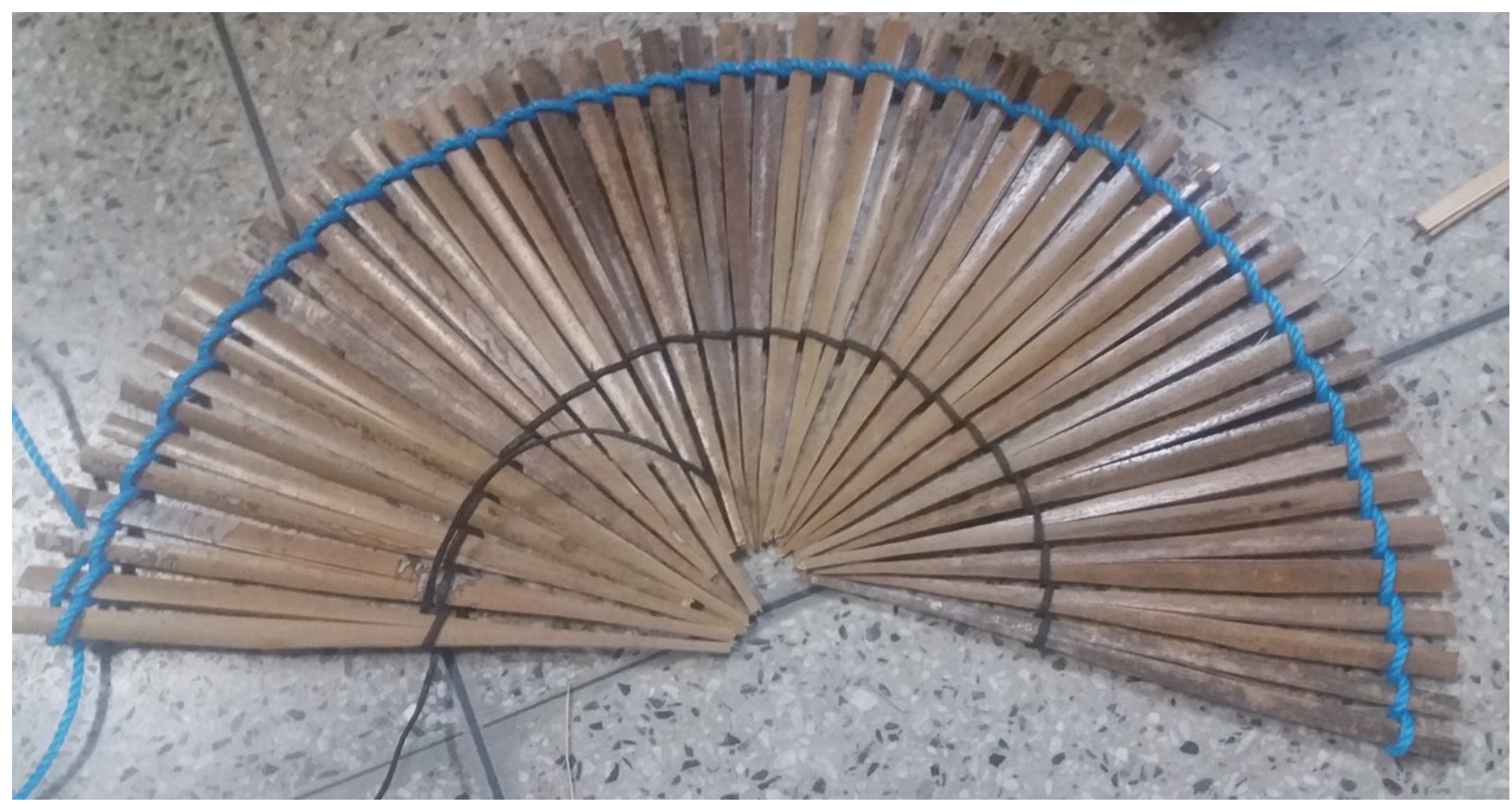

Fonte: Dados da pesquisa (2019) 
$4^{\circ}$ Passo: Com a sobra do náilon, faça o trançado na outra extremidade, para com isso, fechar a língua, que lembra um tronco de cone, em seguida com esse mesmo fio, divida a língua em duas partes iguais e faça a amarração do trançado menor para o maior, conforme imagem.

$5^{\circ}$ passo: Pressione a língua no corpo do matapi, pegue a agulha palheta já enfiada no barbante e costure-os, apertando bem o barbante em toda a circunferência do corpo, fazendo, com isso, o trançado final.

Figura 14 - Enchuliamento com barbante e agulha palheta

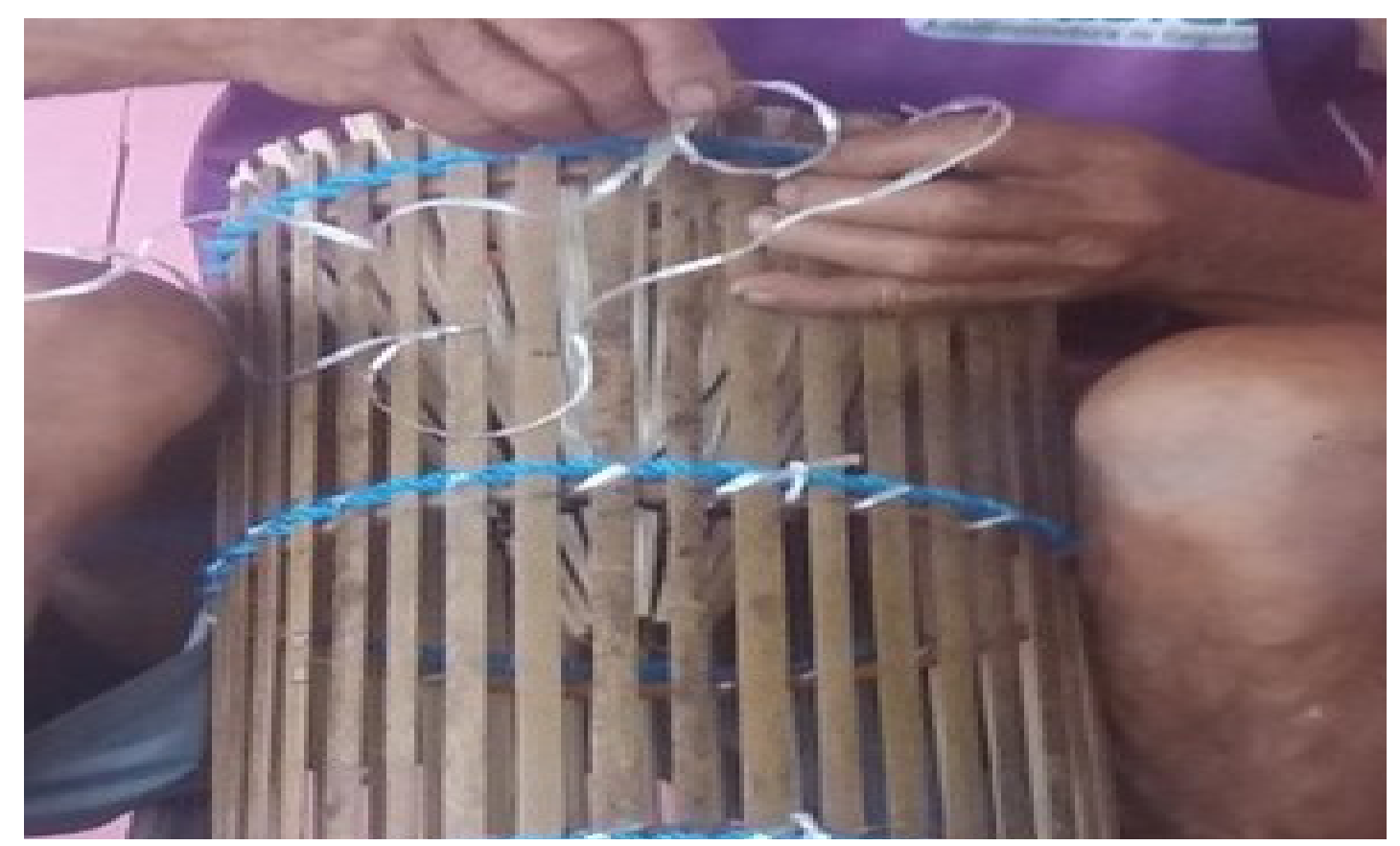

Fonte: Dados da pesquisa (2019)

Agora, coloque outra língua da mesma forma que você costurou a primeira, finalizou com êxito.

\subsubsection{Etapa da construção da janela}

\section{$1^{\circ}$ passo:}

Com auxílio da faca, faça um corte específico no corpo do matapi, localizado entre às duas línguas. Mobiliza-se uma determinada categoria de técnica, para fazer essa janela, sendo a porta de entrada para se colocar a isca e de onde também se retira o camarão. 
- Usar uma serra de aço ou faca;

- Cortar cinco talas do corpo do matapi, com uma abertura de $9 \mathrm{~cm} \times 7,5 \mathrm{~cm}$ (medida matapi da natureza);

- Para a construção da janelinha, usar 07 talas, fazendo o trançado nas extremidades, usando aproximadamente meio metro de náilon de 2 ou 3 capas conforme a demonstração da imagem.

Figura 15 - Construção da janela

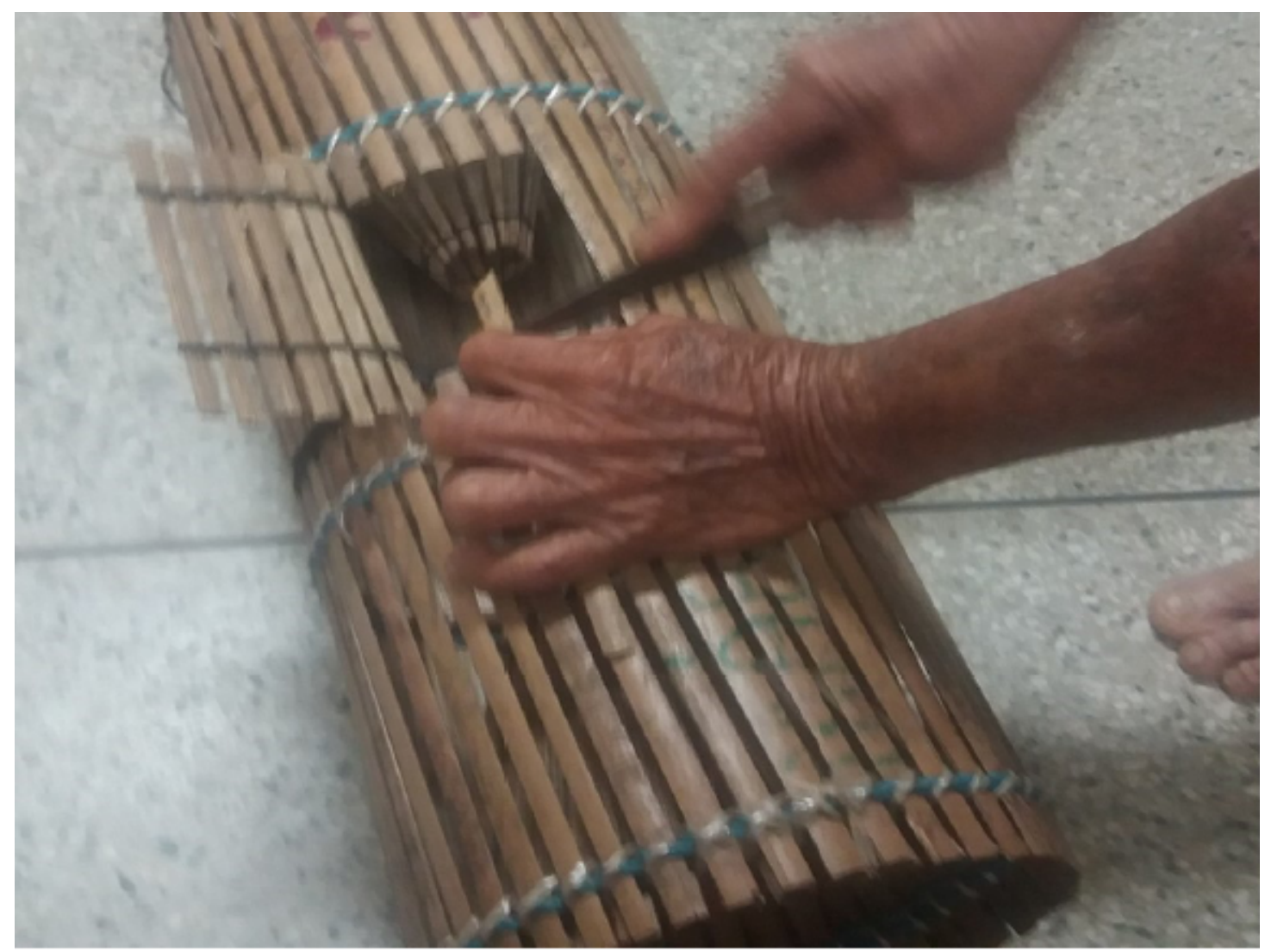

Fonte: Dados da pesquisa (2019)

\subsection{Medidas para a construção do matapi - geogebra formato tambor}

\subsubsection{Construção do tapete (medidas)}

$>$ Comprimento $x$ altura do tapete: $51 \mathrm{~cm}$ por $94 \mathrm{~cm}$;

$>58$ talas de $51 \mathrm{~cm}$ de comprimento que equivale aproximadamente 20 polegadas; 
> $5 \mathrm{~mm}$ distância entre as talas do tapete do matapi;

> Usar fio de náilon de $4 \mathrm{~mm}$ ou $5 \mathrm{~mm}$ em diante;

> Dividir o tapete em quatro partes iguais, sendo a distância de um trançado para outro de $06 \mathrm{~cm}$. Em cada divisão, usar náilon de 2,20 cm de comprimento.

\subsubsection{Construção da língua.}

> Usar 27 talas para a construção da língua, cortada no formato duas em uma;

> Diâmetro da borda maior 09 polegadas, equivalente a $23 \mathrm{~cm}$;

> Diâmetro da borda circular menor 2,5 polegadas, aproximadamente $6 \mathrm{~cm}$;

$>$ Comprimento da tala da língua de $24 \mathrm{~cm}$;

> A distância entre as duas línguas de $10 \mathrm{~cm}$, que equivale aproximadamente 4 polegadas;

> Para fazer o trançado da parte circular da borda menor, utiliza-se náilon tipiti de três capas e para o fechamento, utiliza-se o náilon $n^{\circ} 36$.

\subsubsection{Amarração das rodas}

> Utilizar o barbante enfiado na agulha palheta para reforçar a amarração de cada uma das rodas que compõe a parte interna do matapi, total 4 rodas;

$>$ Usar esse mesmo processo para costurar a língua ao corpo do matapi.

\subsubsection{Construção da janela do matapi}

$>$ Fazer o corte da janela entre as duas línguas;

$>$ Fazer um corte de $8 \mathrm{~cm}$ por $8 \mathrm{~cm}$;

> Utilizar 06 talas de $12 \mathrm{~cm}$ de comprimento para fazer essa janelinha;

$>$ Para fazer a amarração da janela, utiliza-se 02 pedaços de náilon de $65 \mathrm{~cm}$. 


\subsection{Medidas do Matapi- Geogebra número 11}

\subsubsection{Construção do tapete}

- 53 talas de $70 \mathrm{~cm}$ de comprimento, cortadas no formato duas em uma;

> $4 \mathrm{~mm}$ distância entre as talas do tapete do matapi;

$>4 \mathrm{~mm}$ ou $5 \mathrm{~mm}$ fio de náilon;

> Dividir o tapete em quatro partes iguais, sendo a distância de um trançado para outro de $21 \mathrm{~cm}$. Em cada divisão, usar náilon de 2,20cm de comprimento;

Comprimento $x$ altura: $74 \mathrm{~cm}$ por $70 \mathrm{~cm}$.

\subsubsection{Construção da língua}

$>24$ talas nas línguas;

$>$ Diâmetro da borda maior 22cm;

Diâmetro da borda menor $3 \mathrm{~cm}$;

> Comprimento da tala da língua $25 \mathrm{~cm}$;

> Para o segundo trançado da língua, utiliza-se náilon tipiti de 3 capas e para o seu fechamento, utiliza-se náilon $n^{\circ} 36$;

> A distância entre as duas línguas é de $25 \mathrm{~cm}$.

\subsubsection{Construção da porta}

> Abertura da porta: $8 \mathrm{~cm}$ por $19 \mathrm{~cm}$;

> Cortar 06 talas para a porta;

> Utiliza-se 2 pedaços de náilon de $65 \mathrm{~cm}$ de comprimento para tecer a porta. 


\subsubsection{Problema inicial: $Q_{0}$}

A partir da leitura do manual de como se faz um matapi, responda as seguintes questões.

Trabalhando com língua portuguesa sobre variação linguística, figuras de linguagem

$Q_{1}$ - O que é língua?

$Q_{2}$ - Por que é empregado o termo língua?

$Q_{3}$ - Por que se usa o termo língua do matapi?

$Q_{4}$ - O que significa o uso da faca, alicate?

$Q_{5}$ - O que significa o uso da palavra enchuliamento?

$Q_{6}$ - Faça o que se pede:

a) O que significa a expressão: "costurar a língua ao corpo do matapi"? O tipo de linguagem empregada?

b) O que significa corpo do matapi?

c) O que significa "Costurar a língua do matapi"?

Trabalhando matemática sobre tipos de medidas e suas transformações; figuras planas e espaciais

$Q_{1}$ - Quais os tipos de medidas sugeridos no manual para fazer o matapi?

$\mathrm{Q}_{2}$ - Transforme os náilons de 4 milímetro $(\mathrm{mm})$ e 5 milímetros $(\mathrm{mm})$ para centímetro (CM).

$\mathrm{Q}_{3}$ - Transforme a medida do plástico de PVC de $5 \mathrm{~cm}$ de comprimento em metros?

$\mathrm{Q}_{4}$ - Transforme $51 \mathrm{~cm}, 23 \mathrm{~cm}, 10 \mathrm{~cm}$ em polegadas?

$Q_{5}$ - Como definir polegadas?

$Q_{6}$ - Como definir medidas? Exemplos. 
$Q_{7}$ - O que significa milímetro, centímetro, metro?

$Q_{8}$ - Mostre em forma de desenho como seria o tapete do matapi de $74 \mathrm{~cm}$ por $70 \mathrm{~cm}$ ?

$Q_{9}$ - Mostre em forma de desenho o tapete do matapi de $51 \mathrm{~cm}$ por $94 \mathrm{~cm}$ ?

$Q_{10}$ - Mostre em forma de desenho como seria a distância de $4 \mathrm{~mm}$ entre as talas do tapete do matapi de $74 \mathrm{~cm}$ por $70 \mathrm{~cm}$.

$Q_{11}$ - Mostre em forma de desenho o diâmetro da borda maior da língua do matapi com 22cm;

$Q_{12}$ - Mostre em forma de desenho o diâmetro da borda menor da língua do matapi com $3 \mathrm{~cm}$;

$Q_{13}$ - Mostre em forma de desenho a distância entre as duas línguas do matapi de $10 \mathrm{~cm}$ uma da outra.

$Q_{14}$ - Represente em forma de desenhos com que figuras geométricas se parecem o:

a) Tapete do matapi de Comprimento $x$ altura: $74 \mathrm{~cm}$ por $70 \mathrm{~cm}$.? Por que?

b) Tapete do matapi de comprimento $\mathrm{x}$ altura: $51 \mathrm{~cm}$ por $94 \mathrm{~cm}$ ?

c) Abertura da porta do matapi com $8 \mathrm{~cm}$ por $19 \mathrm{~cm}$ ? Por que?

d)Construção da janela do matapi de corte de $8 \mathrm{~cm}$ por $8 \mathrm{~cm}$

c) Língua do matapi aberta? Por que?

d) Língua do matapi fechada? Por que?

e) Matapi? Por que?

$Q_{15}$-Considerando o Comprimento $x$ altura de $74 \mathrm{~cm}$ por $70 \mathrm{~cm}$, dívida o tapete em quatro partes iguais 


\section{Trabalhando com ciências sobre espécies de plantas e sustentabilidade ambiental}

$Q_{1}$ - Descreva como é o cipó de cebola braba e agrachama? Tem nome científi$\mathrm{Co}$ ?

$\mathrm{Q}_{2}$ - Descreva como e leite de breu? E como é extraído da natureza? (nessa questão,)

$Q_{3}$ - Descreva como é a tala de jutapi seca? E como é retirada da natureza?

$Q_{4}$ - Pra que serve o plástico de PVC? Ele é sustentável?

$Q_{5}$ - Pra que serve o fio de náilon? Como ele é feito?

$Q_{6}$ - Como o fio de náilon pode ser sustentável?

$Q_{7}$ - Como a tala de jutapi pode ser sustentável?

\section{Trabalhando com geografia sobre preservação ambiental, sustentabilidade ambiental}

$Q_{1}$ - Como preservar a natureza a partir da construção do matapi?

$Q_{2}$ - Pode ser feito matapi sustentável?

\section{Trabalhando com educação física}

$Q_{1}$ - Descreva a posição que se deve fazer para o tecimento do matapi?

$Q_{2}$ - Sobre a posição que se faz para tecer o tapete do matapi, responda as seguintes questões:

a) Quais os pontos positivos para a saúde?

b) Quais os pontos negativos para a saúde?

Observação: Dependendo das respostas dos alunos com relação as questões, encaminha-se outras questões e assim a sequência didática caminha para outros campos de saberes. 


\subsection{Atividades interdisciplinares envolvendo o matapi}

\section{Leia o texto:}

O matapi é um instrumento usado para a pesca de camarões, peixes, porém na pesca de camarões a construção da língua ou boca nos lembra a forma de um funil, que nos recorda a figura geométrica de um tronco de cone. Conforme a história, suas características culturais parecem ter sido herdadas dos índios, quando um menino indígena fez um cercado para prender a cobra-grande que o desejava engolir (LANA, 2019): "saberes construídos por populações que tem nas águas, além de uma fonte de alimentação, uma fonte de referência simbólica e mística" (MORAES, 2005, p.24).

Raimunda Elizangela Wanzeler (2018) elaborou alguns poemas sobre o matapi e sobre isso ela diz: "o poema no sentido da leitura vai muito além da leitura da palavra. O meu poema ganha vida pelo sentido da história do meu matapi com a realidade atual este poema se ler com a alma. A poesia se ler com a alma construindo imagem expressa visão".

Figura 16 - Matapi

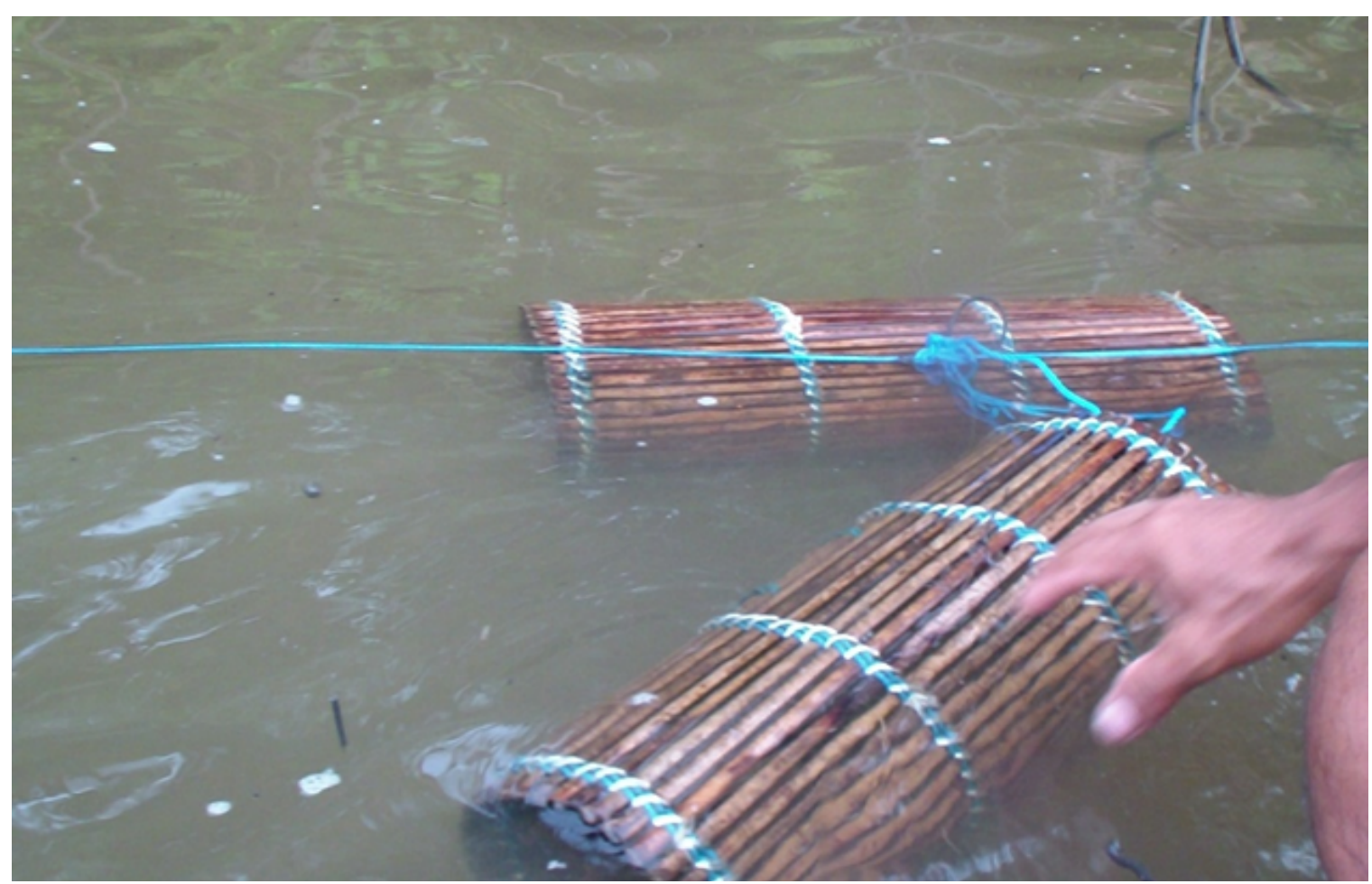

Fonte: Dados da pesquisa, 2021 
Matapi com ele vê poetiza contemporânea

Quem de nós vai separar o matapi e o mar sem você

Mata-PI

Aata-Pi

Rata-Pi

Bata-Pi

Sata-Pi

Cata-Pi

Tata-Pi

Data-Pi

Vata-Pi

Eata- Pi

Xata-Pi

Fata-Pi

Zata-Pi

Jata-Pi

Pata-Pi

Kata-Pi

Oata-Pi

Lata-Pi

Nata-Pi 


\section{POEMA 2 - CONSTRUÇÃO DO MATAPI}

Assim? È assim

Que se faz um matapi

Tece um tapete com 58 talas. Ah!

Aqui está fácil $E$ agora?

Fecho e coloco as rodas dentro Meu

Deus Estou me enrolando epa! Pera aí;

Agora vamos tece as línguas;

como então?

Agora me deu medo

Agora vamos cortar a boca? O quê?

Meu Deus, quantos cortes?
Meu matapi tem cheiro de paticulim. Mas parece de verniz Com a cor de marfim vou tecendo

meu matapi

Pi-ri-rin(tem cheiro de paticulim) Ma-Má-Má

$\mathrm{T}$ a -

Tá- ta

$\mathrm{Pi}-\mathrm{Pi}-$

$\mathrm{Pi}$

Olha que coisa mais linda é o meu matapi

\section{POEMA 3 - CONVERSANDO COM O CAMARÃO}

Fui no rio jordão perguntei

para o camarão

O que você gosta mais de comer?

Me respondeu: Babaçu cheiroso

vou viajando pela maré

Vou remando na enchen-

te adoro! Fazer serenata

Gosto de enamorar

Fico escondido coladinho no meio dos

paus das raízes das arvores
Do buraco, sai da

família do- ba-be-

-bi-bo-bu Bando

Belo

Bilisco aqui aquolá

Bolo de babaçu escondidinha

No buraco 


\section{POEMA 4 - PREPARANDO O CAMARÃO}

Preparo do camarão

Salada de camarão vou comendo de montão;

Quer saber como eu aço

Vou falar é bem baixinho pego um

panelão corto pimentão

Corto batatão corto o cenorão corto o repolhão corto camarão

Pula camarão na panela quem nem pipoca

Abenta camarão na aba do meu saião vai dançando no salão

Vou durando de montão nessa imensa multidão

Dentro do meu matapí

Primeiro, tiro a isca e vou batendo

meu matapí.

Meu único matapí
Você que vê o camarão fica feliz é pôr a isca nova Dentro do matapi

Aí eu grito estou tão feliz Professorinha está na cozinha fritando o camarão para a Renatinha Eu sou a poetisa do matapí

Matapí

Neste estilo caboclo vou batendo meu matapí

Vou com fé, Vou com certeza,

Que meu camarão vem aí. Vou puxando a corda do meu matapí

Fico tão feliz em ver os camarões dançando

Cai um montão de camarão que me faz tão feliz Jogo com carinho meu matapí na água, $\mathrm{E}$ digo até mais tarde matapí.

Figura 17 - Retirando o matapi do rio

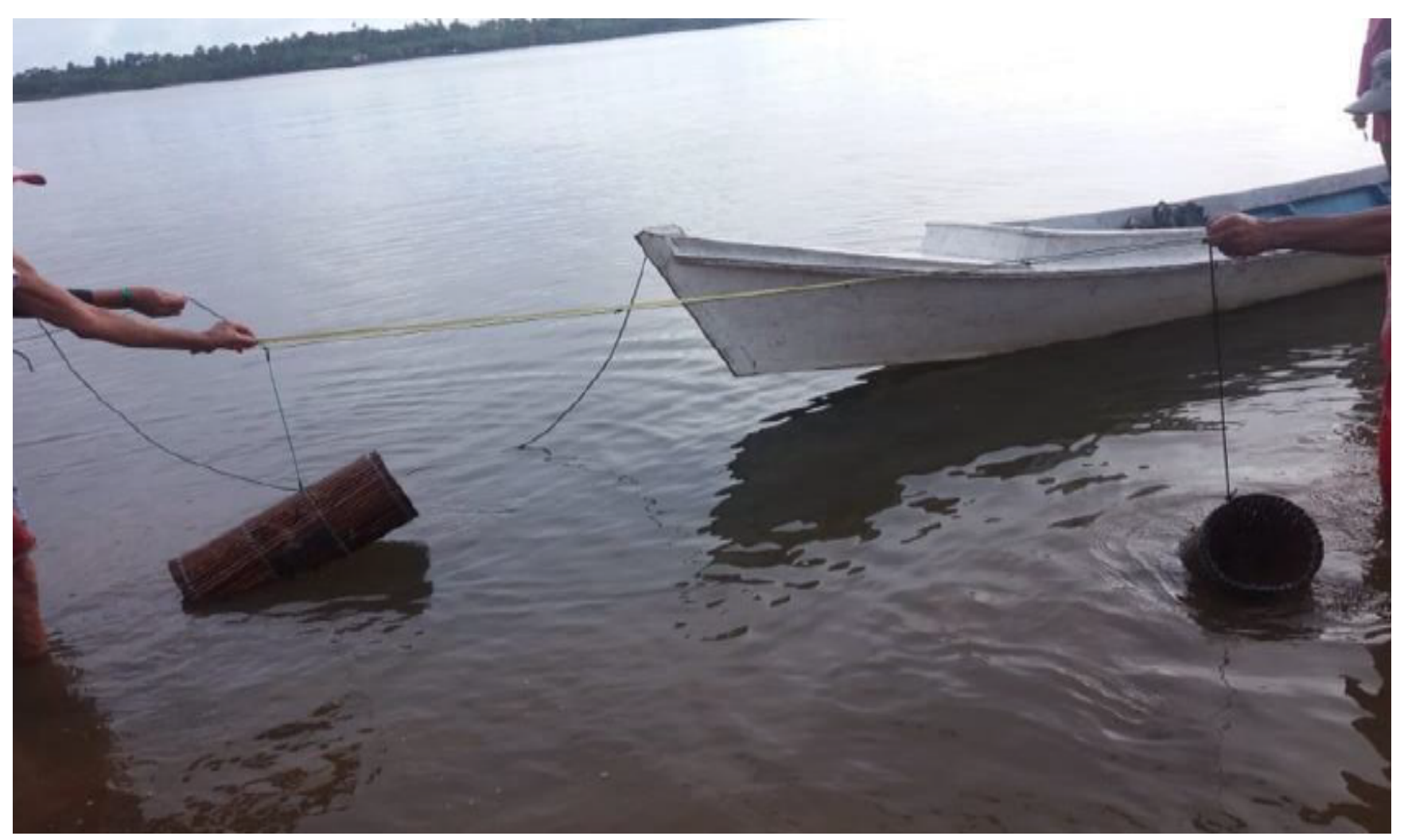

Fonte: Autores, 2019. 


\title{
POEMA 5 - FANTASIA DO MATAPI
}

\author{
Sonhei que estava no meu tapete \\ feito de matapi \\ como se fosse meu Aladim \\ Dizendo plim-plim
}

\section{POEMA 6 - REAPROVEITAMENTO DO MATAPI}

Conserta-se matapi. O velho vira novo. Garanto-te que não vou se arrepenMexa e faça de novo! Loja do matapi. der de comprar o valente matapi.

Olha o matapi- pi. Quem vai quererer. Custa (mil R\$, obs.: aparecem as cédulas?) OBS: Não deu o preço.

Quero ver você fazer agora eu pergunto quanto vale o matapi que você fez.

Ah. Agora te digo.

Não tem preço é uma obra de arte para mim.

Olha o Barco do matapi passando no seu rio. Psi vem vê como é macio.

$E$ te digo mais. Esse é o poderoso tupi- matapi.

Numa noite de luar levo meu matapi à praia lá começa a contempla-lo.

Meu poderoso matapi começa a contar as talas como se fossem os grãos de areia que não se podem contar ligando a ponte à beira do mar.

Autora dos poemas: Raimunda

O meu matapi leve como o vento chega Elizangela Wanzeler ${ }^{38}$ até flutuar nas águas.

$Q_{0}$ - Problema inicial:

A partir da leitura do texto sobre o matapi e dos poemas, elenco algumas sugestões de atividades interdisciplinares para trabalhar com as disciplinas de:

38 Professora que lecionou na educação infantil, na escola situada na ilha de Pacuí de baixo 


\section{Trabalhando com História}

1) Como se originou o matapi?

2) O que é cultura?

3) Como definir cultura ribeirinha e indígena?

4) Por que o matapi foi construído com duas bocas? Pode ser feita com outras?

5) Em que comunidades o matapi está presente?

6) Qual a importância histórica do matapi para o contexto social da Amazônia?

7) O que é a Amazônia?

8) Quais as características históricas da Amazônia?

\section{Trabalhando com Geografia}

1) Em que local surgiu o matapi?

2) A construção do matapi varia de acordo com o lugar? Por quê?

3) O matapi usado na ilha de Pacuí, é o mesmo que o matapi usado no cupijó?

4) Quais as condições de uso do matapi?

5) Como é construído o matapi?

6) Para fazer o matapi, é preciso desmatar a natureza?

7) O matapi pode ser feito de garrafas petes?

8) As garrafas poluem o meio ambiente? Por quê?

9) O matapi construído com talas de jupati, polui menos o meio ambiente do que aquele construído 8) 8) com garrafas petes?

10) Qual a importância desse matapis para o desenvolvimento sustentável da Amazônia?

11) O matapi pode ser encontrado em que lugares? Cite-os? 
12) O matapi pode ser encontrado no continente americano? Por quê?

13) Como definir continente americano?

\section{Trabalhando com Ciências}

1) O matapi é usado para capturar que tipos de alimentos? Por quê?

2) Para capturar o camarão, por exemplo, se usa que tipo de isca? O que é isca?

3) A isca é prejudicial à saúde?

4) O camarão se alimenta de que?

5) O camarão é classificado em que classe?

6) Quais as características do camarão?

7) Será que o camarão de Cametá, tem as mesmas características do camarão de Belém, Maranhão? Por quê?

8) Por que o camarão é um ser vivo?

9) Que tipos de alimentos usamos para fazer o camarão?

10) Se pode produzir matapis sustentáveis com reflorestamento da natureza? Ainda assim, continua sendo uma criação divina?

\section{Trabalhando com Língua portuguesa}

1) De que o texto trata?

2) Quais os saberes culturais que podem ser identificados nos poemas?

3) Que tipo de linguagem é usada nos poemas?

4) O que significa a palavra língua, boca, funil?

5) Como interpretar a frase: "saberes construídos por populações que tem nas águas, além de uma fonte de alimentação, uma fonte de referência simbólica e mística" (MORAES, 2005, p.24). 
6 Quais os verbos que aparecem no texto, qual a função deles?

7 Quais os aspectos linguísticos presentes em cada um dos poemas? Descreve-os

8 Como se pode classificar os poemas?

9 Os poemas mostram que tipo de realidade? Por que?

\section{Trabalhando com Religião}

1-Que tipos de crenças existem sobre o matapi?

2-O que são crenças?

3-Por que o matapi é "uma fonte de referência simbólica e mística" (MORAES, 2005, p.24).

4-Os recursos naturais usados para fazer o matapi com talas de jupati , é uma criação divina? Por quê?

5-Os horários de colocar e retirar o matapi da água, obedece a uma criação divina? Por quê?

\section{Trabalhando com Matemática}

\section{1-Qual a quantidade de talas que se usa para fazer o matapi?}

2-Com que forma geométrica se parece o matapi? Por quê?

3-Qual a influência das distâncias entre as talas do matapi para a captura do camarão?

4-O que é distância? Como definir?

5-Como calcular o volume do matapi? 


\section{Trabalhando com Artes}

1-Descreva como é o matapi? Desenhando-o?

2-Que aspectos culturais observa no matapi?

3-A arte de construir matapi veem da cultura indígena?

4-Existem outras artes de construir matapi? Mostre

\section{Trabalhando com Educação física}

1)-Qual é a posição que se faz para construir o matapi? Por quê?

2)-O Matapi pode ser construído em qualquer posição?

3)-A posição que se constrói o matapi prejudica a saúde? Por quê?

4)-De acordo com os critérios da saúde física, que tipos de movimentos e posições devem ser realizado para a construção? 


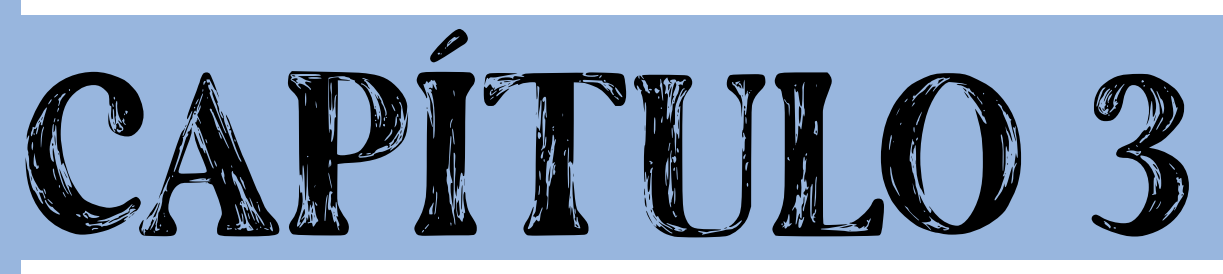

ENGENHARIA DIDÁTICA REVERSA ESTUDANDO MANIPULAÇÃO DO

CONJUNTO DE POTENNCIA E ÁREAS 
O método de ensino da EDR, segue ao processo da desconstrução (estuda as partes que compõe uma determinada prática cultural, buscando compreende-la por meio da transposição didática (CHEVALLARD, 2009a) e da reconstrução (prática melhorada a partir da problematização e criatividade, onde os alunos Irã construindo suas próprias respostas, seguindo as orientações dos professores. Nesse processo investigativo, tanto alunos como professores aprendem e reinventam a prática em estudo, pois nenhuma fala é mais importante que a outra, ambos constroem conhecimento (CHEVALLARD, 2009 c).

Com isso, elenca-se mais três atividades, que podem ser desenvolvidas na educação infantil, fundamental I, II, ensino médio.

A tarefa 4,1 representa a prática desconstruída do conjunto de potência e área, pois a manipulação do papel chamex, eve-a e papelão, sendo uma prática cultural e vive tanto no "habitat" do meio social quanto da escola, encaminha a construção do jogo denominado conjunto de potência e área, usado para o entendimento de áreas, perímetros de figuras planas e suas relações com o estudo de potências.

\subsection{Tarefa envolvendo o uso do papel chamex , eva e papelão}

\section{Tarefa inicial}

$Q_{0}$ : Construa um desenho que tenha a forma de um terreno. Use uma folha de papel podendo ser chamex ou papel quadriculado, régua, fita métrica. Vamos supor que o terreno tem a forma 8 por 6. 
Figura 18 - Representação do terreno 8 por 6 em papel chamex e papel EVA

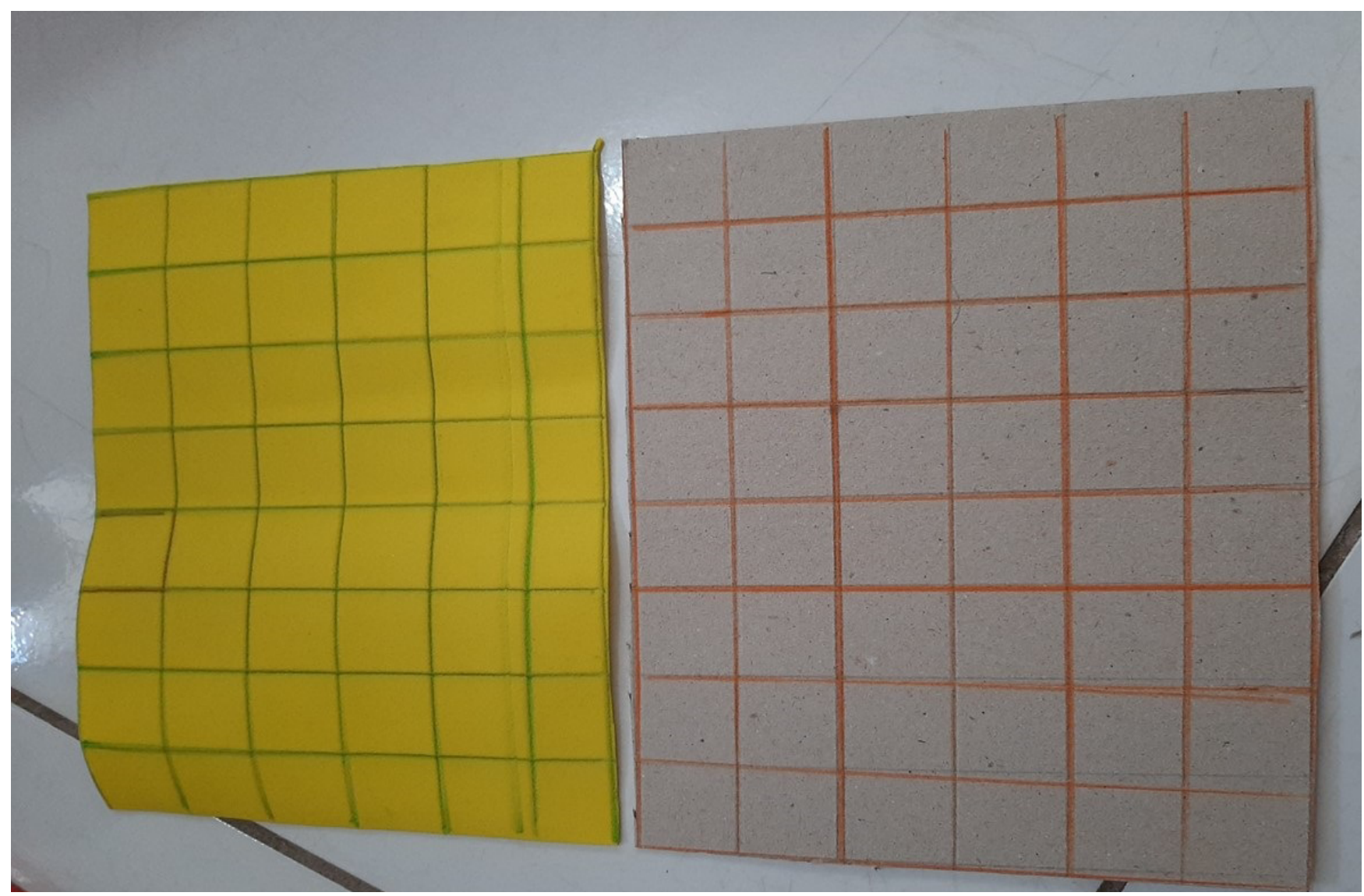

Fonte: Dados da pesquisa (2020)

Atividades para os $3,4,5,6,7,8,9$ anos do fundamental I e II

$Q_{1}$ ) Comprimento e altura do terreno construído? (Tarefa)

$Q_{2}$ ) Descreva a forma do terreno? (Tarefa)

\section{Desconstrução da técnica}

$Q_{3}$ ). Como foi construído o terreno? (Técnica)

$Q_{4}$ ). Para que foi construído dessa maneira? (Tecnologia)

Reconstrução da tarefa

$\left.Q_{5}\right)$. Por que foi construído dessa maneira? Existem outras formas de fazê-los? (Teoria) 
3.1.1 Execução da nova tarefa a partir da Q0

$Q_{6}$ ) Agora desenhe dois terrenos com as mesmas medidas da questão $Q_{0}: 8$ de comprimento e 6 de altura. Em um dos terrenos construa três desenhos usando as medidas de $3,4,5,6$, ou 7 . Aqui os alunos irã pensar na técnica de como fazer esses desenhos.

Figura 19 - Construção de três desenhos no terreno

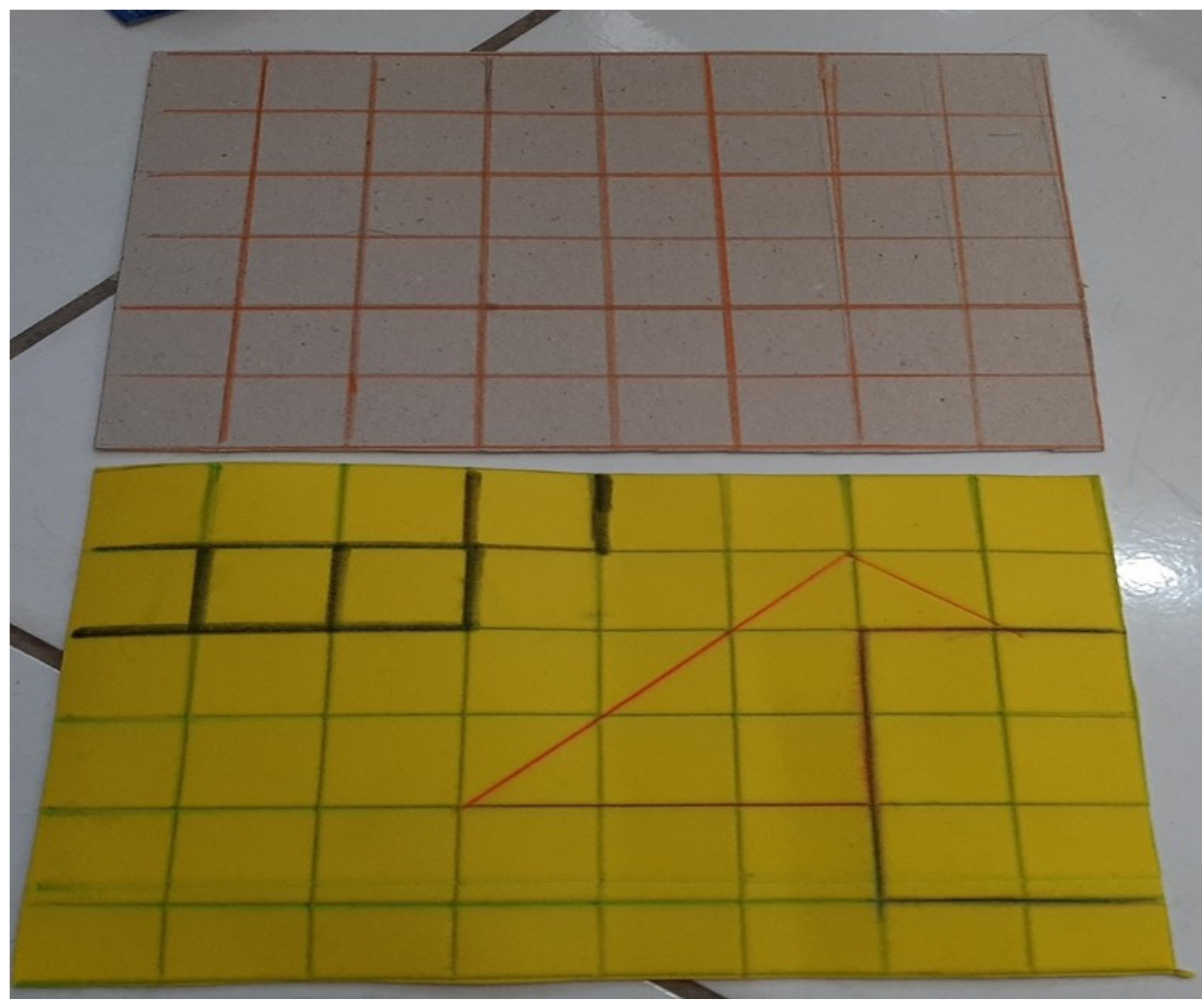

Fonte: Dados da pesquisa (2020)

Nas próximas questões, passos 7 e 8, dar-se-ão as fases da desconstrução do terreno (técnica) 


\section{Desconstrução da técnica}

$Q_{7}$ ) Recorte os desenhos de acordo com a forma construída no terreno (Desconstruindo)

Figura 20 - Recorte dos desenhos (desconstrução)

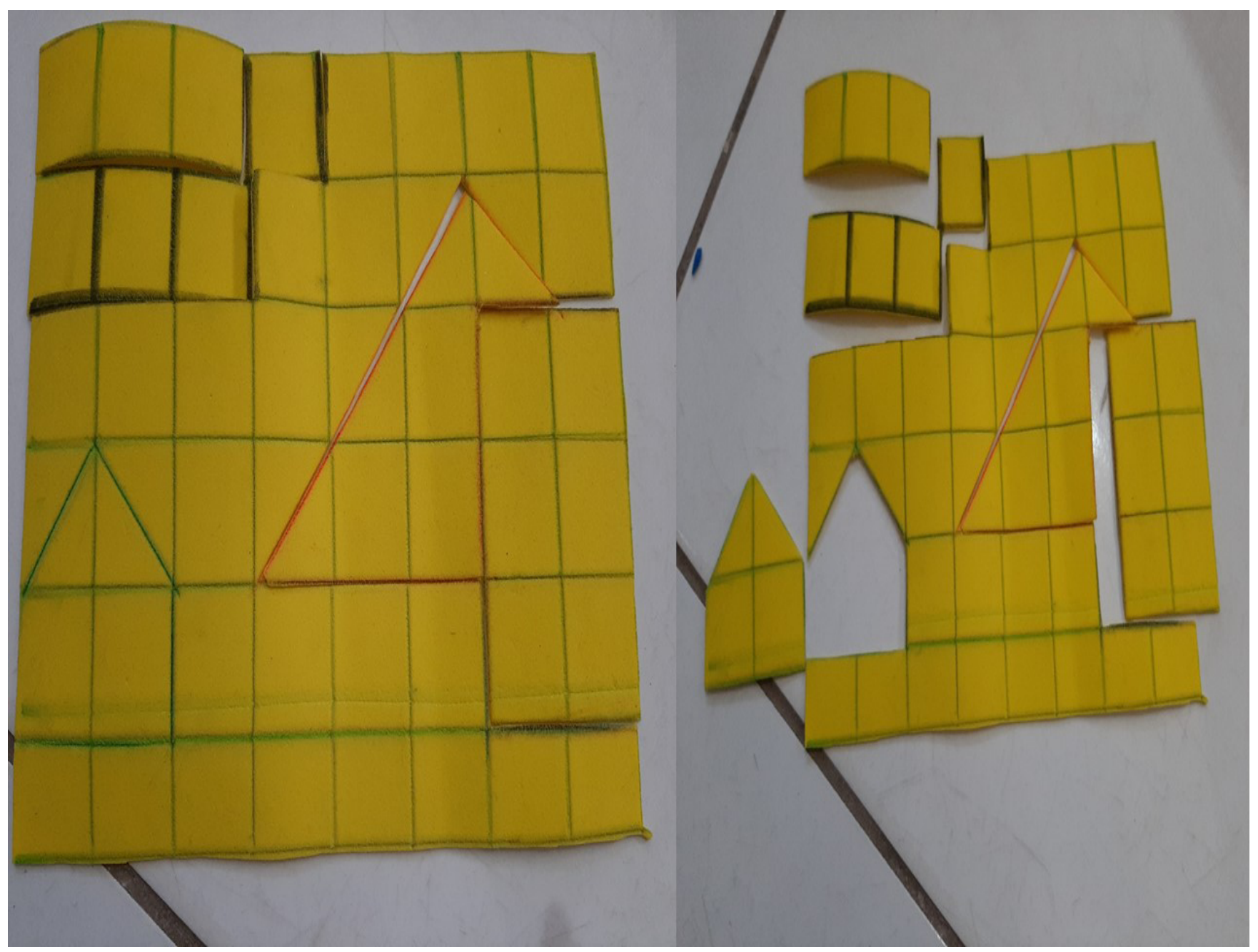

Fonte: Dados da pesquisa (2020)

Após ser recortado os desenhos individualmente, recortá-los novamente em peças menores (desconstruindo novamente). Observe que cada peça recortada de cada desenho se transforma em peças de quebra-cabeças. 
Figura 21 - Cada peça recortada transformou-se em peça de quebra-cabeça

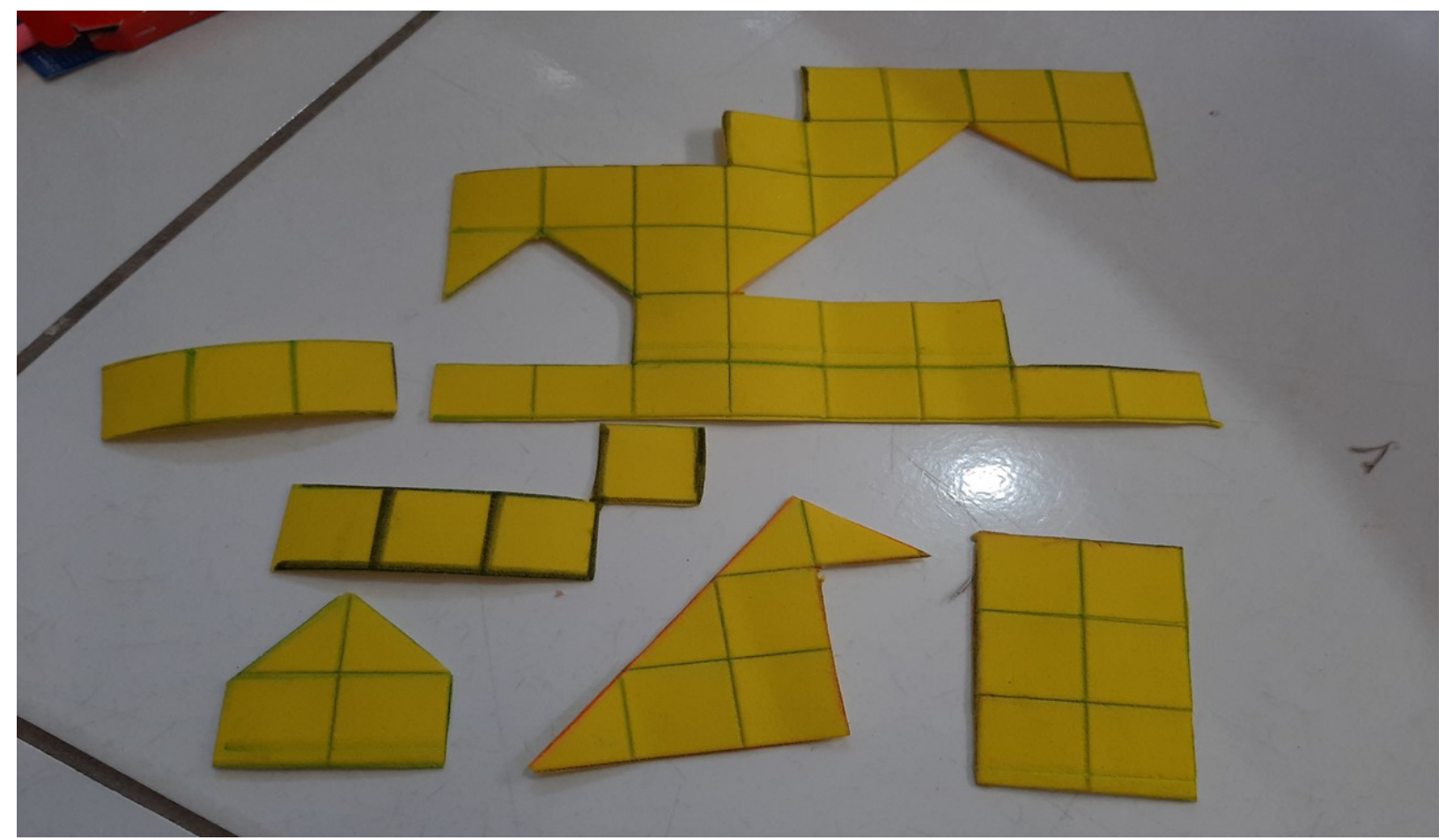

Fonte: Dados da pesquisa (2020)

$Q_{8}$ ) qual a razão dos desenhos serem construídos desse modo? Existem outras maneiras de fazê-los?

\section{Reconstrução da tarefa}

Figura 22 - Cada peça foi descontruída em unidades menores

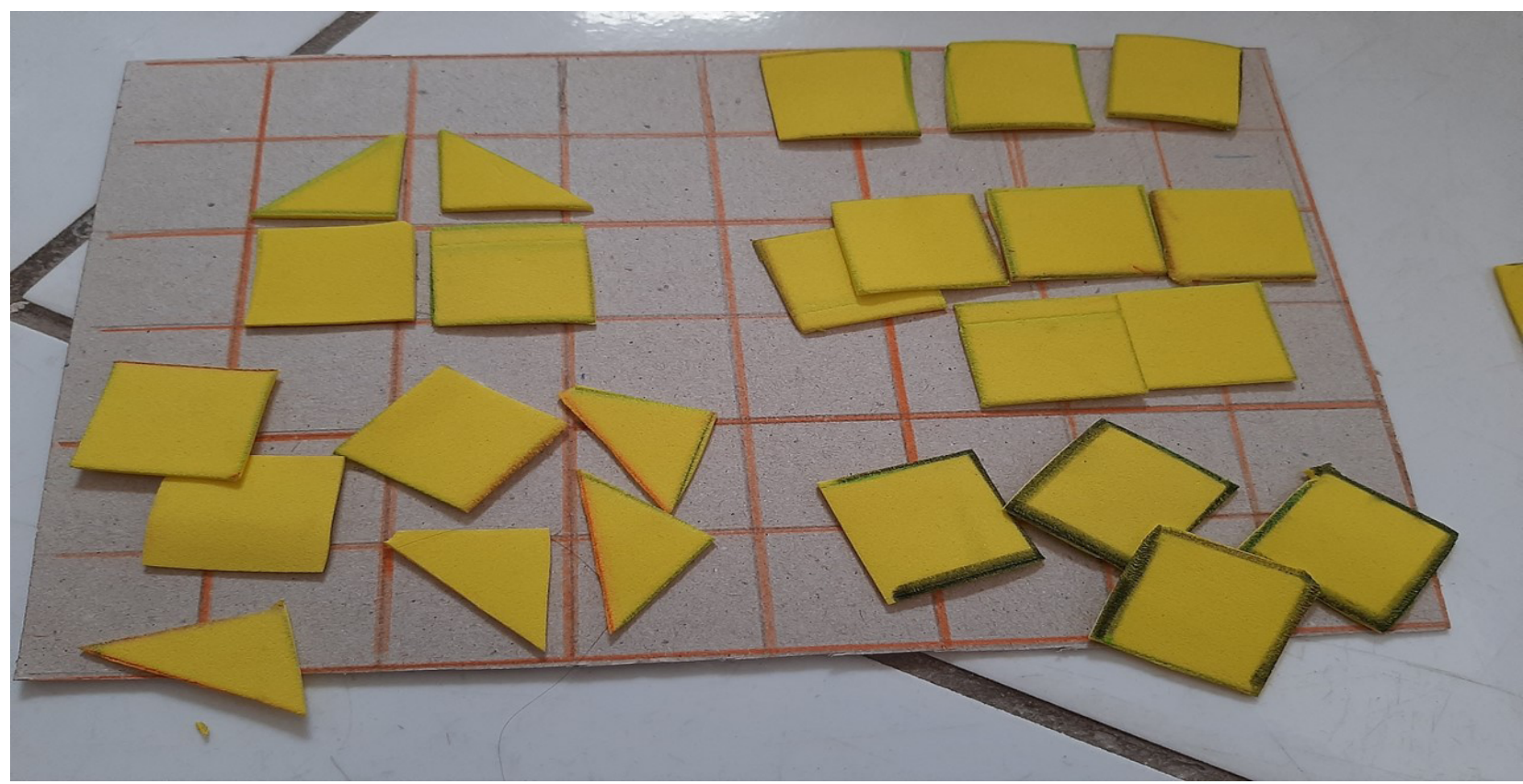

Fonte: Dados da pesquisa (2020) 
Figura 23 - Cada peça dos desenhos desconstruído foi encaixado no outro terreno de mesma natureza, que permaneceu na forma inicial.

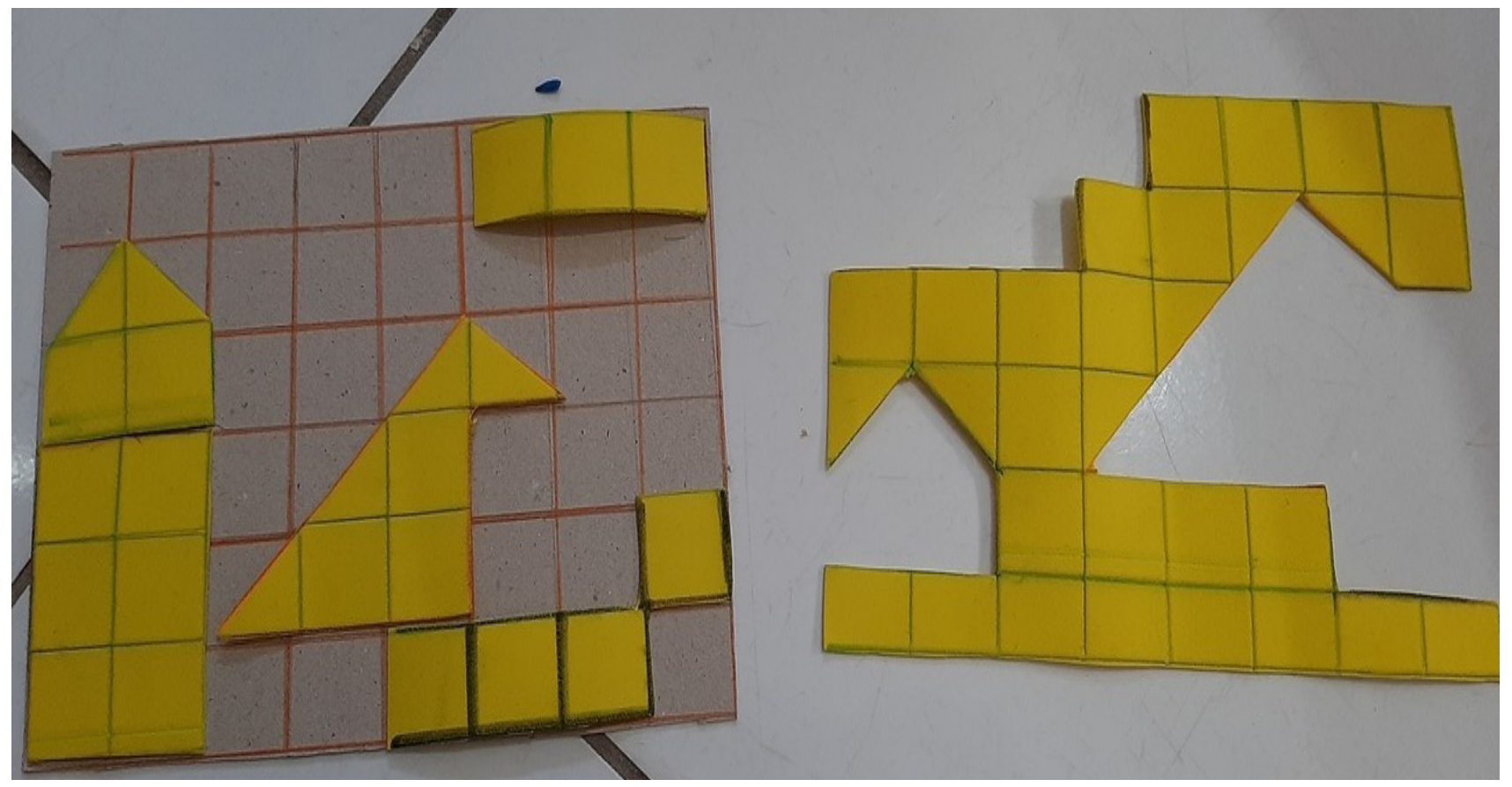

Fonte: Dados da pesquisa (2020)

\subsubsection{Execução da nova tarefa a partir da questão $Q_{6}$}

$Q_{9}$ ) Com todaas as pessoas desmontadas construa novos desenhos sem obedecer a ordem da tarefa $\mathbf{Q}_{6}$.

Figura 24 - Mistura das peças

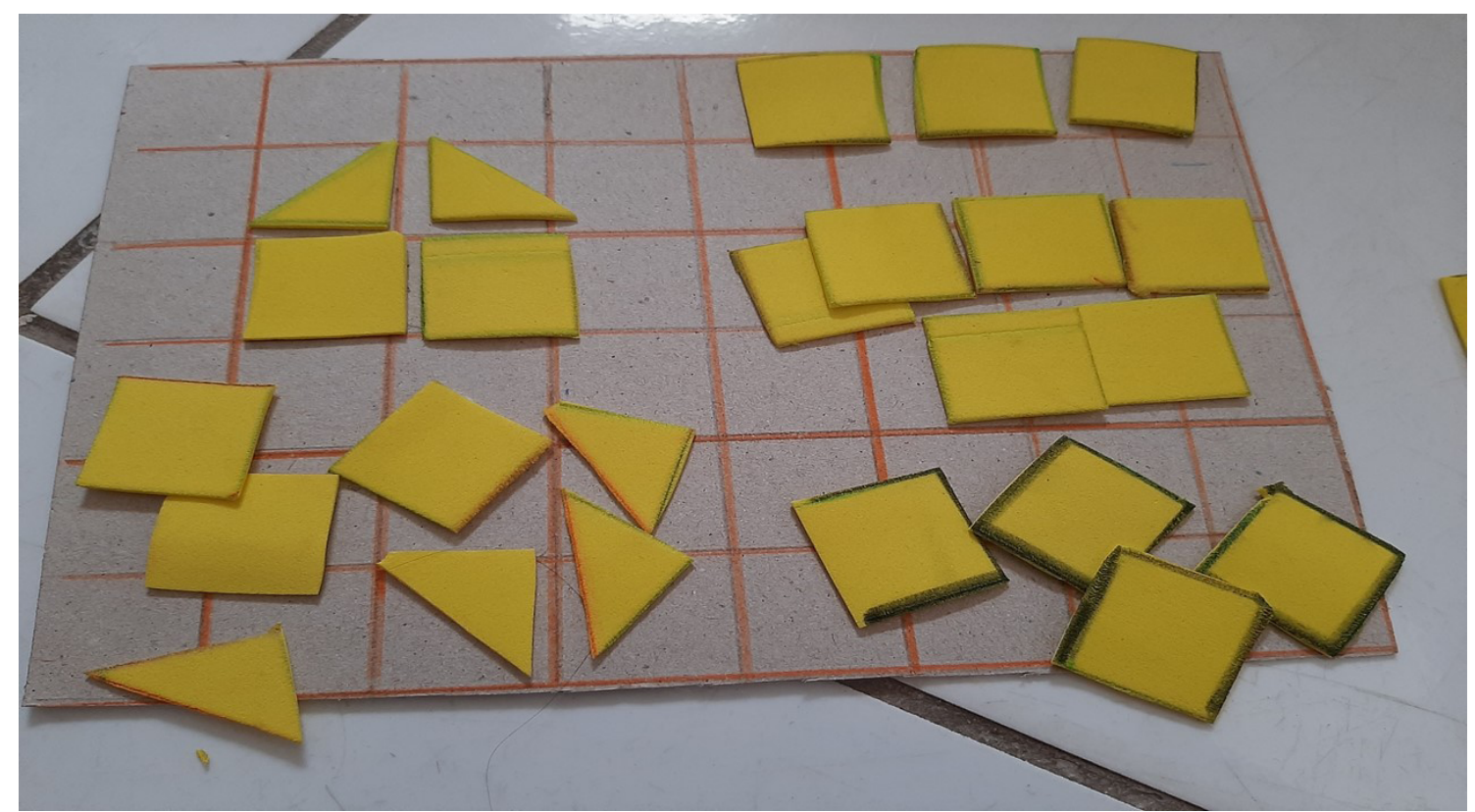

Fonte: Dados da pesquisa (2020) 
Figura 25 - Novos desenhos formados a partir da recombinação das peças

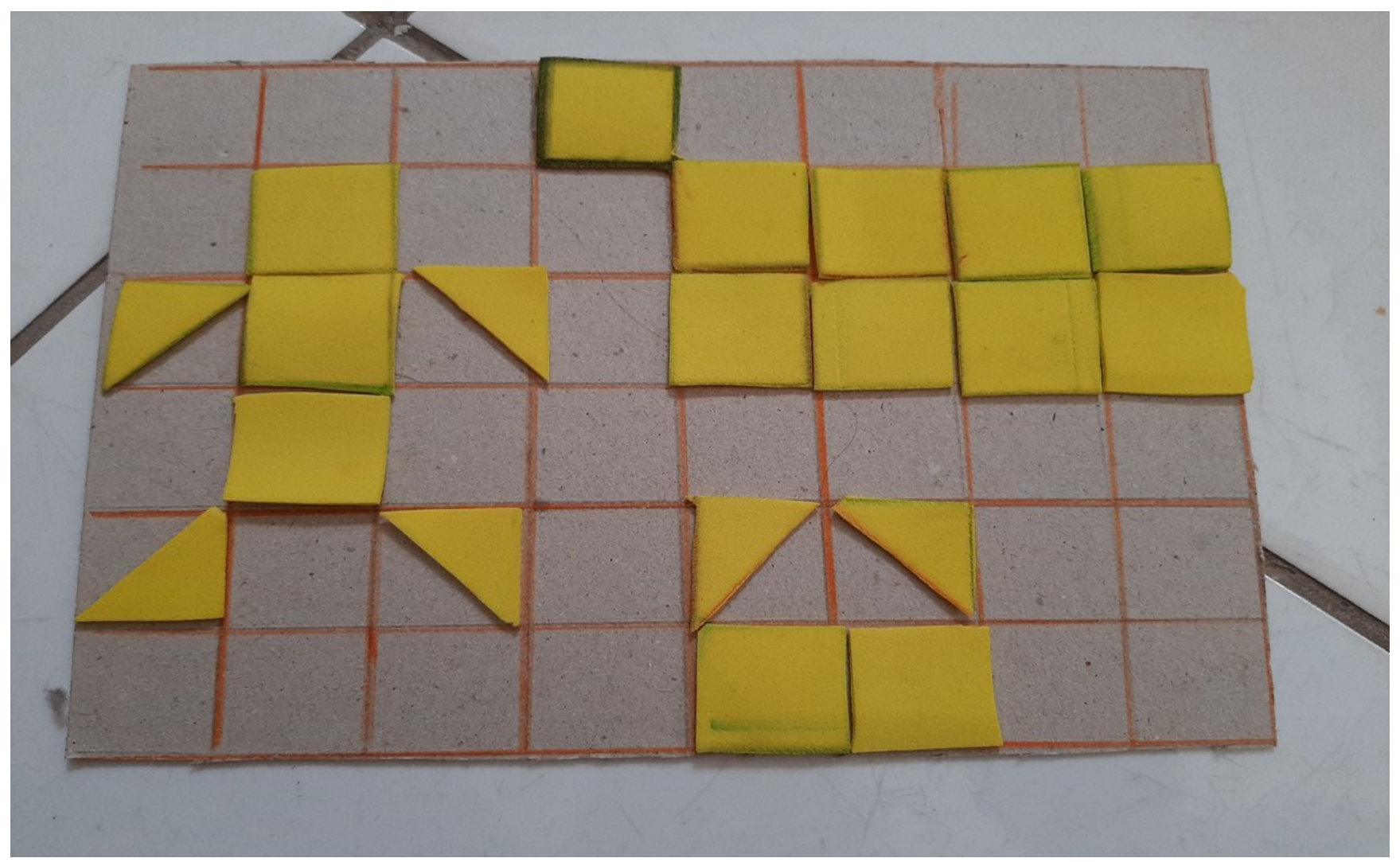

Fonte: Dados da pesquisa (2020)

Sugestões de tarefas para alunos do $5^{\circ}, 6^{\circ}, 7^{\circ}, 8,9$ anos

Q10). Quais as relações que podem ser observadas dos primeiros desenhos com os novos construídos no terreno?

Q11). Por que os novos desenhos foram construídos dessa maneira?

Q12). Com que figura se parece os desenhos? Por quê?

Q13). É possível recortar cada desenho em partes menores? Por quê?

Q12) O que significa essas partes menores? Como defini-las?

Q14). Como podemos construir novos desenhos a partir destes que já temos?

Q15) como podemos fazer a contagem da área e do perímetro desse terreno, tomando como base a figura com qual ele se aparenta?

Q16) O que é área? O que é perímetro? Como definir? 


\section{Sugestões de tarefas sobre matemática voltadas aos}

\section{alunos dos $7,8,9$ anos}

Q17) podemos traçar um plano cartesiano no terreno? Como?

Q18) O que é plano cartesiano? Como definir?

Q19) É possível representar a distância entre dois pontos no terreno?

Q20) É possível representar o Teorema de Pitágoras no terreno?

Q21) É possível fazer gráficos de funções no terreno? Como fazê-los?

Q22) O que é funções? Como defini-las?

Q23) É possível construir ideia de conjunto de potência e área no terreno?

Figura 26 - Outro desenho construído no terreno

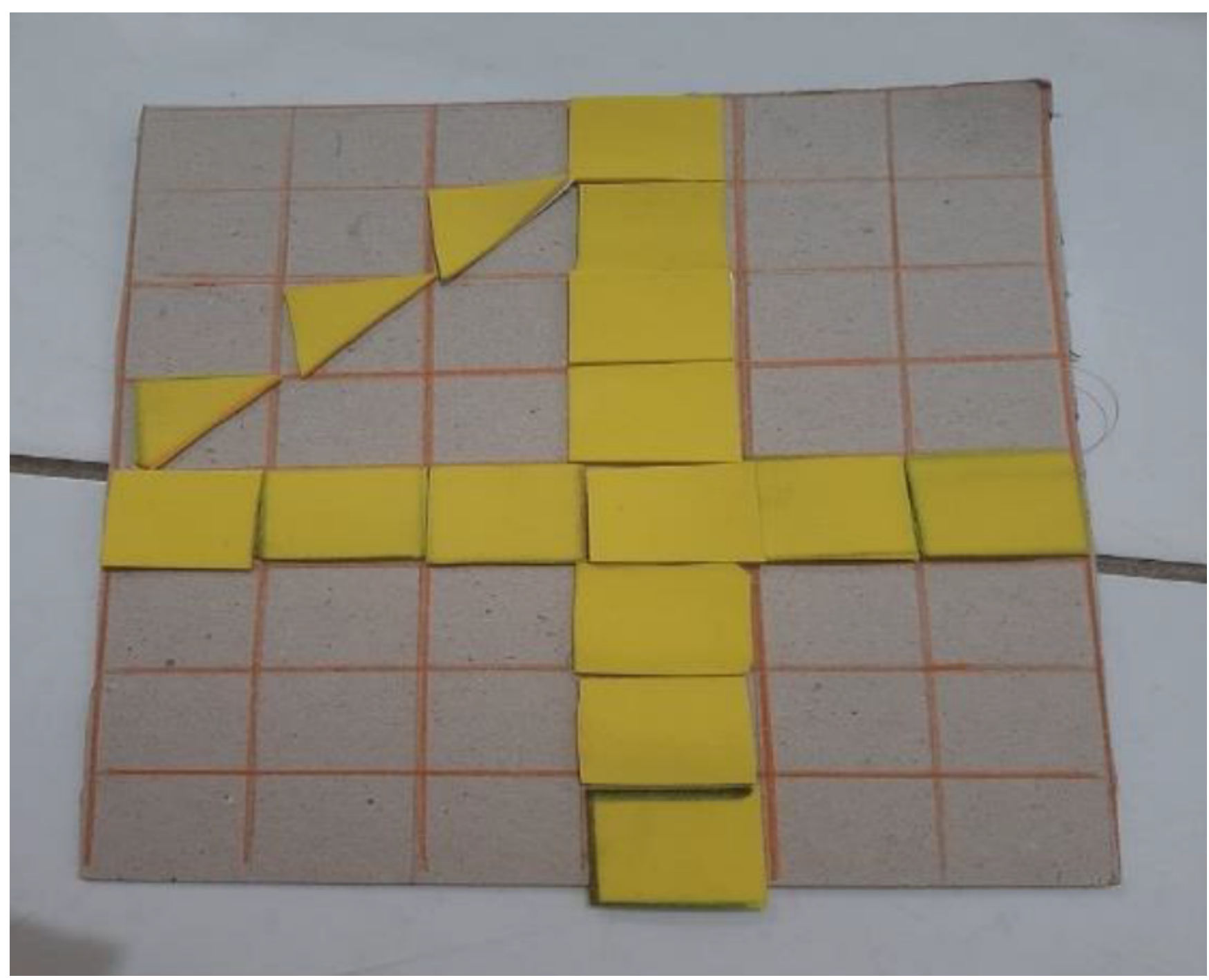

Fonte: Dados da pesquisa (2020) 
Figura 27 - Construção do plano cartesiano

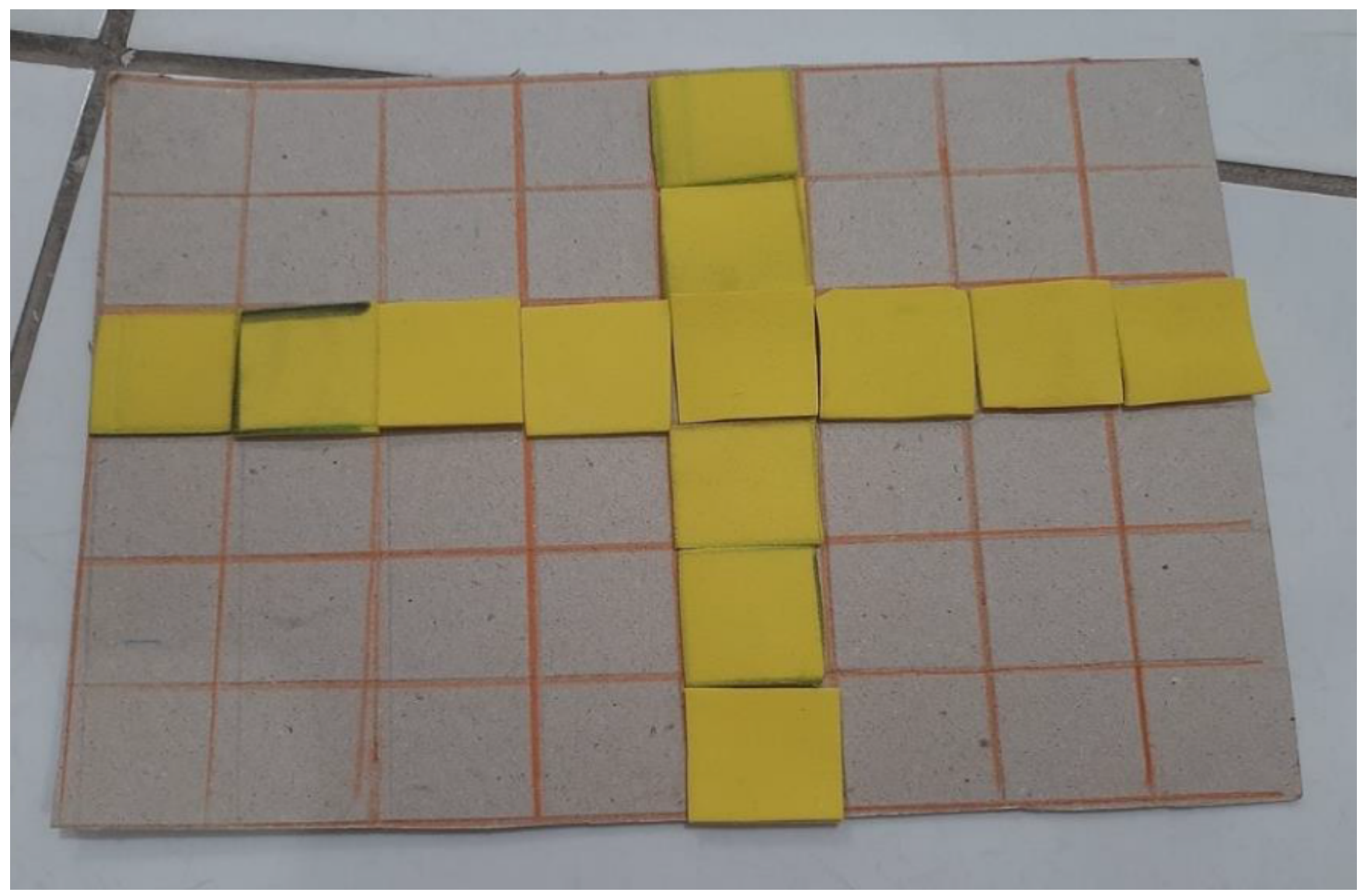

Fonte: Dados da pesquisa (2020)

Figura 28 - Construção da ideia do Teorema de Pitágoras pelo processo da contagem

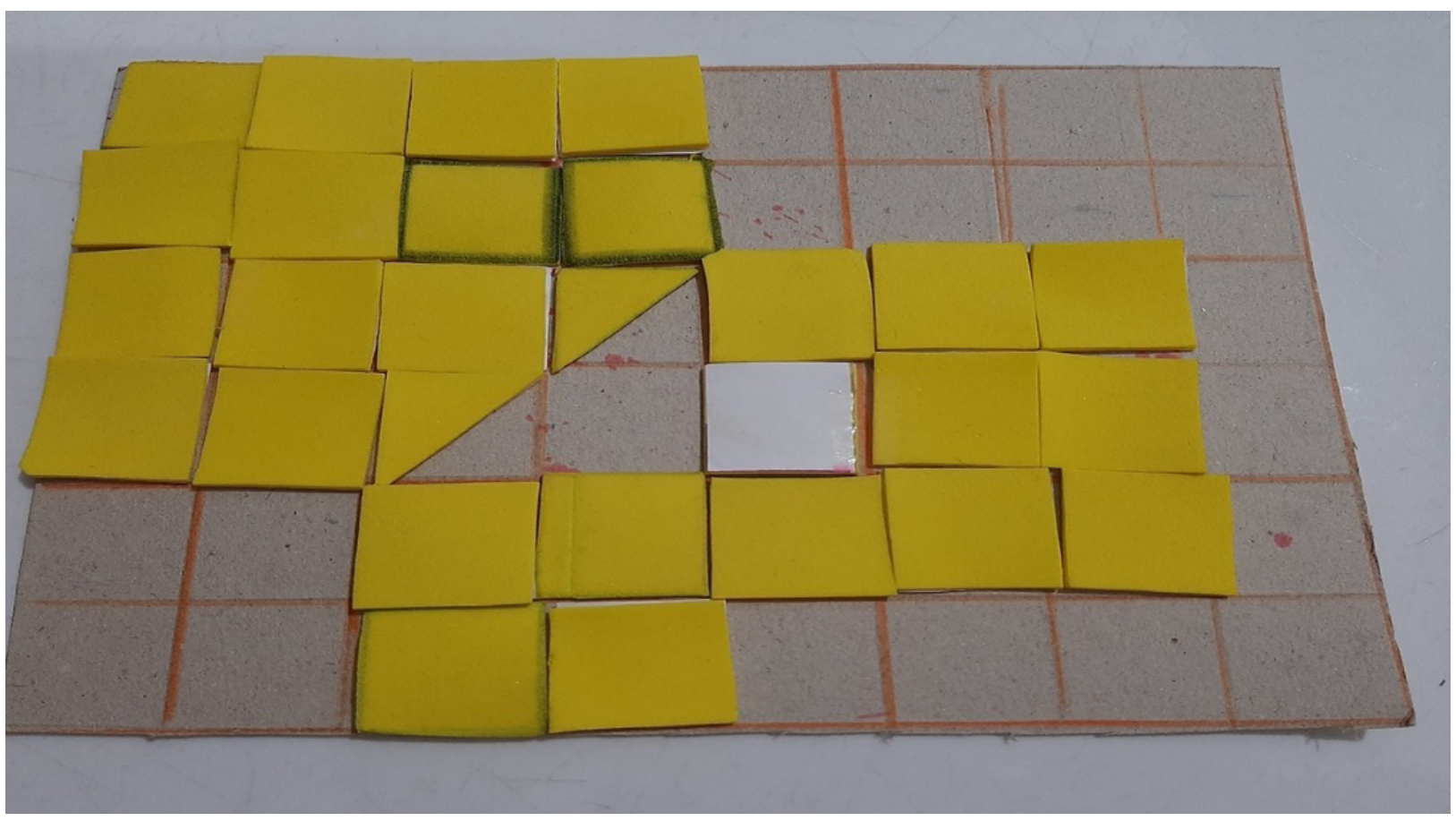

Fonte: Dados da pesquisa (2020) 


\subsection{EDR estudando as caixas de papelões como as de perfumes, sabonetes}

Figura 29 - Caixas de embalagem: Perfume

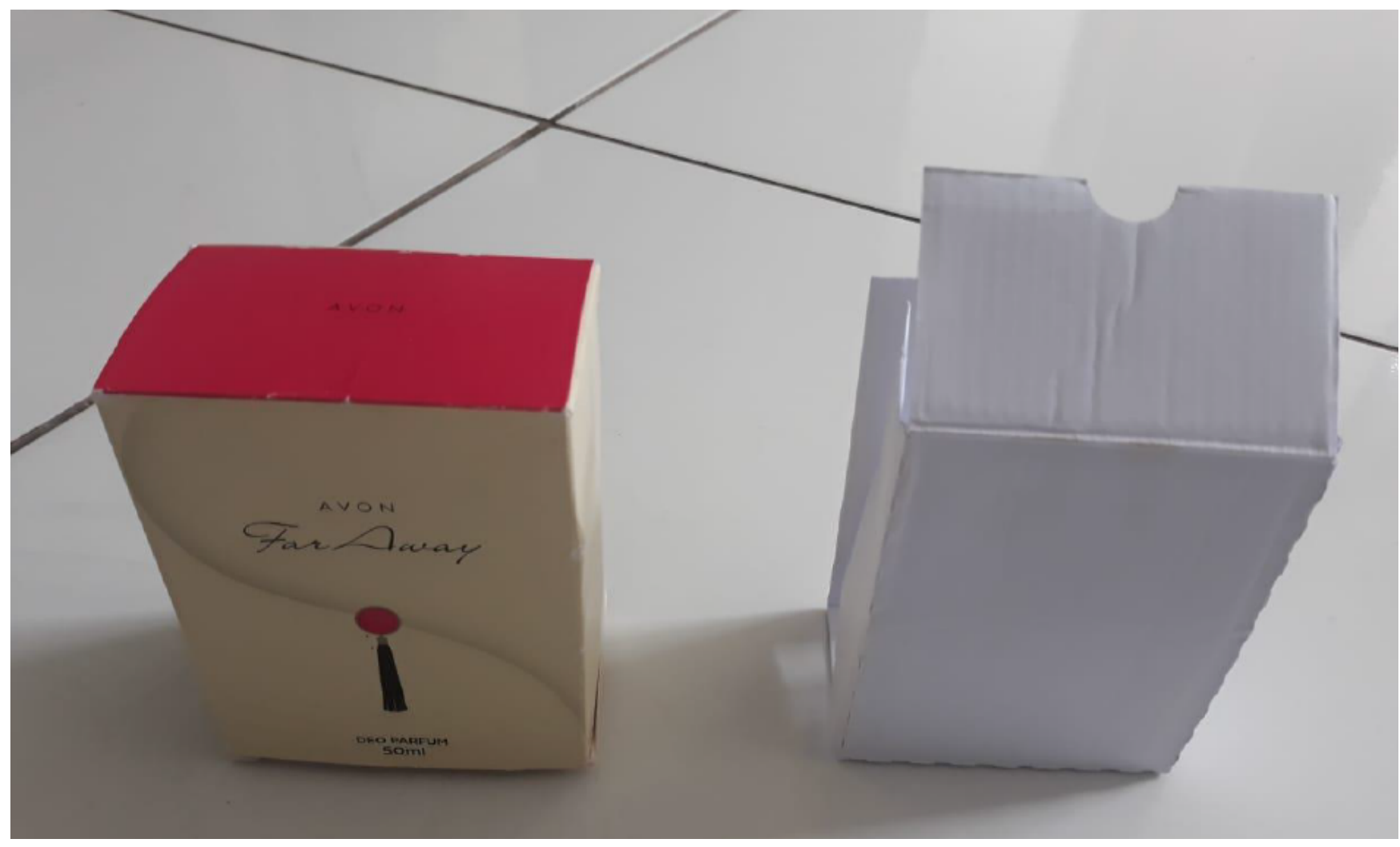

Fonte: Dados da pesquisa (2020)

$1^{\text {a }}$ fase da EDR (desconstrução)- Inicia-se o momento de investigação do material concreto

\section{Sugestões para a educação infantil}

1- Desenhe vários modelos de caixas, para desenvolver a coordenação motora nas crianças

2- Mostre as crianças para que servem as caixas.

3- Use as caixas para montar gráficos e fazer a leitura do mesmo.

Solicite as crianças para trazer caixas

4- Monte brincadeiras para explorar o conceito de aberto e fechado usando as caixas 
5-Monte brincadeiras para explorar o conceito de pequeno e grande, igualdade e semelhanças, perto e longe.

6- Explore o estudo das cores usando as caixas.

Conte a história das vogais:

a)Por que surgiu as vogais?

b) Como surgiu?

c) Em que lugar?

Conte a história do alfabeto:

a)Por que surgiu o alfabeto?

b) Como surgiu?

c) Em que local?

Conte o total de letras que tem o nome da caixa:

a) Explore a ideia de números, contagem, quantidade

b) Conte a história dos números

Sugestões de tarefas para $01^{\circ}, 2^{\circ}, 3^{\circ}$, anos do fundamental

$1^{\text {a }}$ fase da EDR (desconstrução)

Inicia-se o momento de investigação do material concreto

Cada aluno deve manipular a caixa com movimentos de fechar e abrir. Pergunte o que eles notaram com esse movimento.

Desenhe modelos de caixas, para que o aluno possa desenvolver a coordenação motora.

Escreva o nome da caixa e construa atividades sobre:

a) Vogais,

b) Alfabeto, 
c) Sílabas,

d) Formação silábica,

e) Explore a ideia de soma, subtração, multiplicação e divisão

Solicite aos alunos caixas de embalagens diversas.

\section{Explore o movimento de abrir e fechar}

No movimento das caixas abertas e fechadas:

b) -Explore o conceito sobre formas.

c)- Explore o conceito sobre medidas.

Sugestões de tarefas para $4^{\circ}, 5^{\circ}, 6^{\circ}, 7^{\circ}, 8^{\circ}, 9^{\circ}$ anos do fundamental

1 - Solicite aos alunos caixas de embalagens diversas.

2 - Cada aluno deve manipular a caixa com movimentos de fechar e abrir. Pergunte o que eles notaram com esse movimento.

Figura 30 - Movimento de abri e fechar as caixas

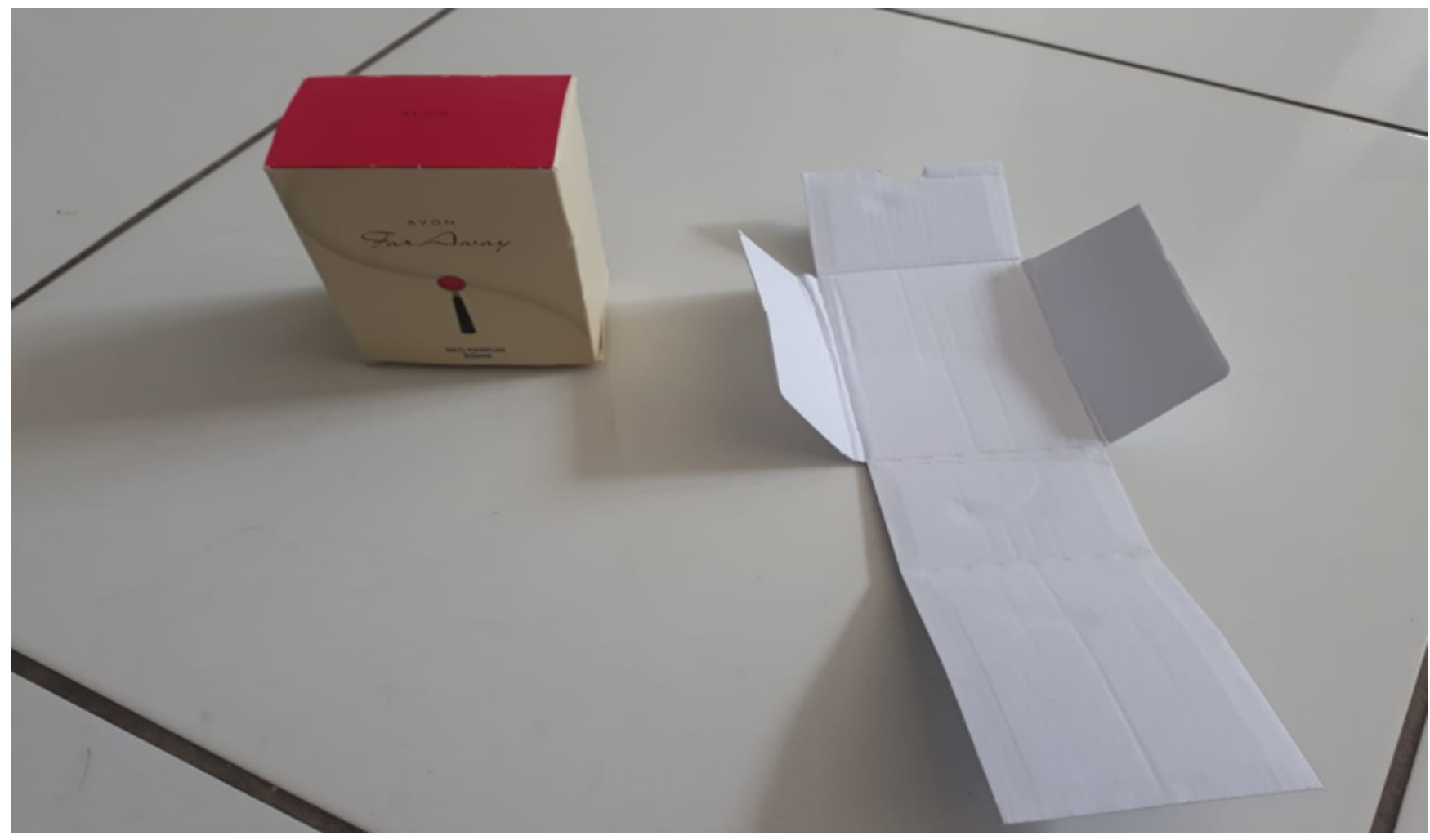

Fonte: Dados da pesquisa (2020) 
$1^{\text {a }}$ fase da EDR (desconstrução)- Inicia-se o momento de investigação do material concreto

3 - Construa um problema inicial para trabalhar com esse movimento de abrir e fechar a caixa. Esse problema pode surgir dos comentários dos alunos acerca dos questionamentos de abrir e fechar.

\section{Problema inicial}

3.1 - Para que serve o uso de caixas de embalagens diversas como de perfume, sabonete?

Qual a intenção de fabricá-las? Como elas são feitas?

Figura 31 - Caixas de sabonete fechada

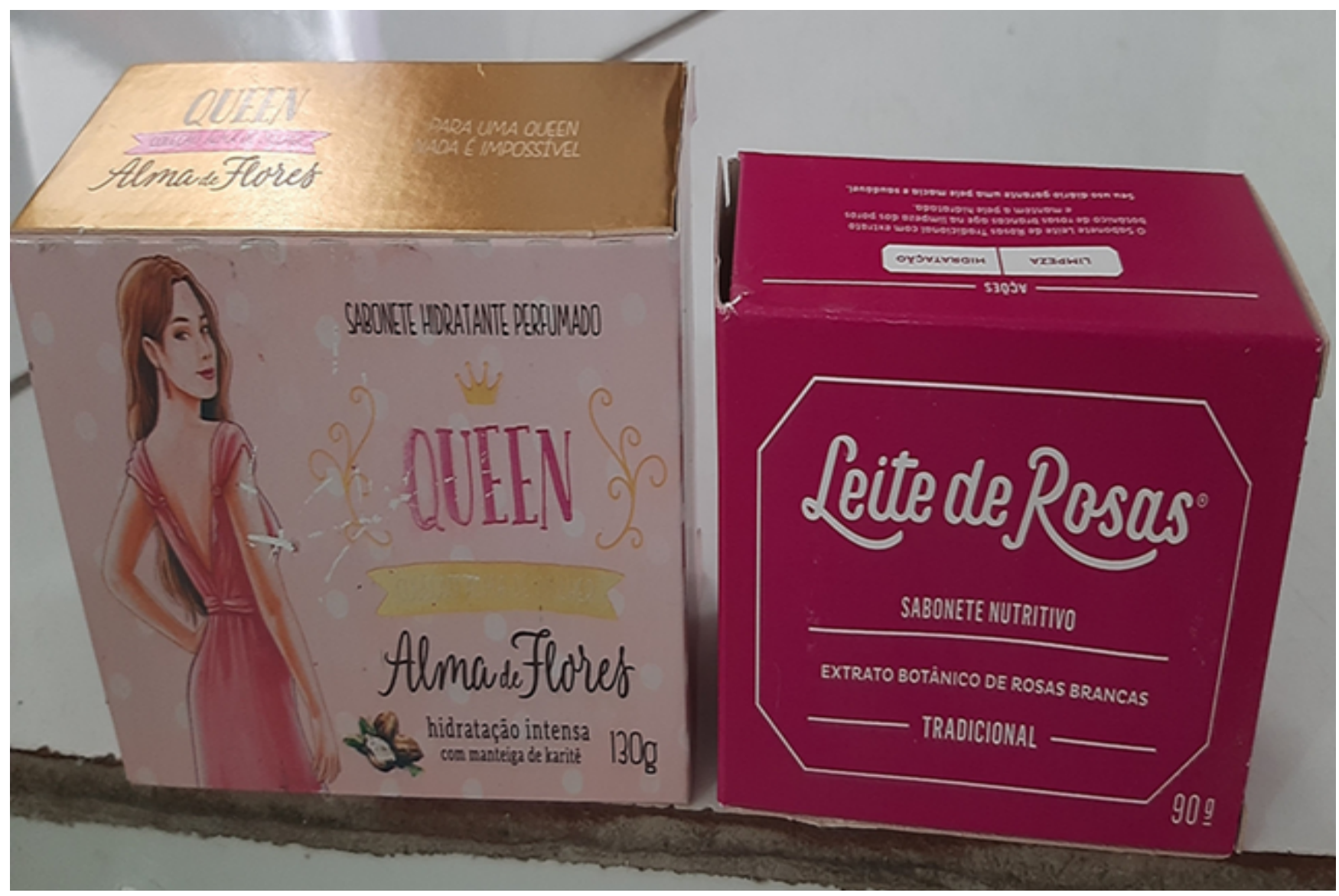

Fonte: Autora, 2021 
Figura 32 - Caixas de sabonetes abertas

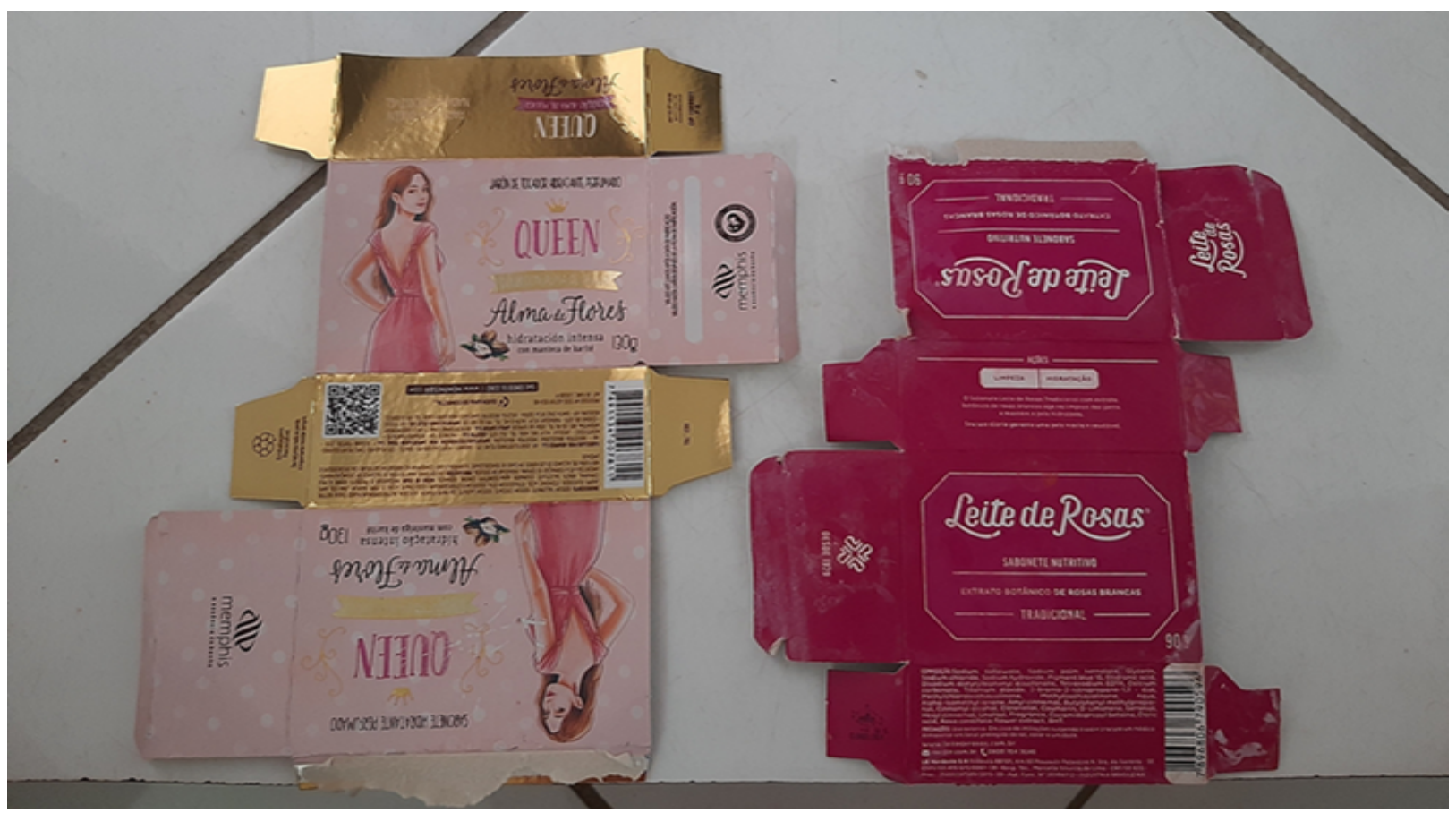

Fonte: Autora, 2021

Figura 33 - Caixas de sabonete em forma de gráficos

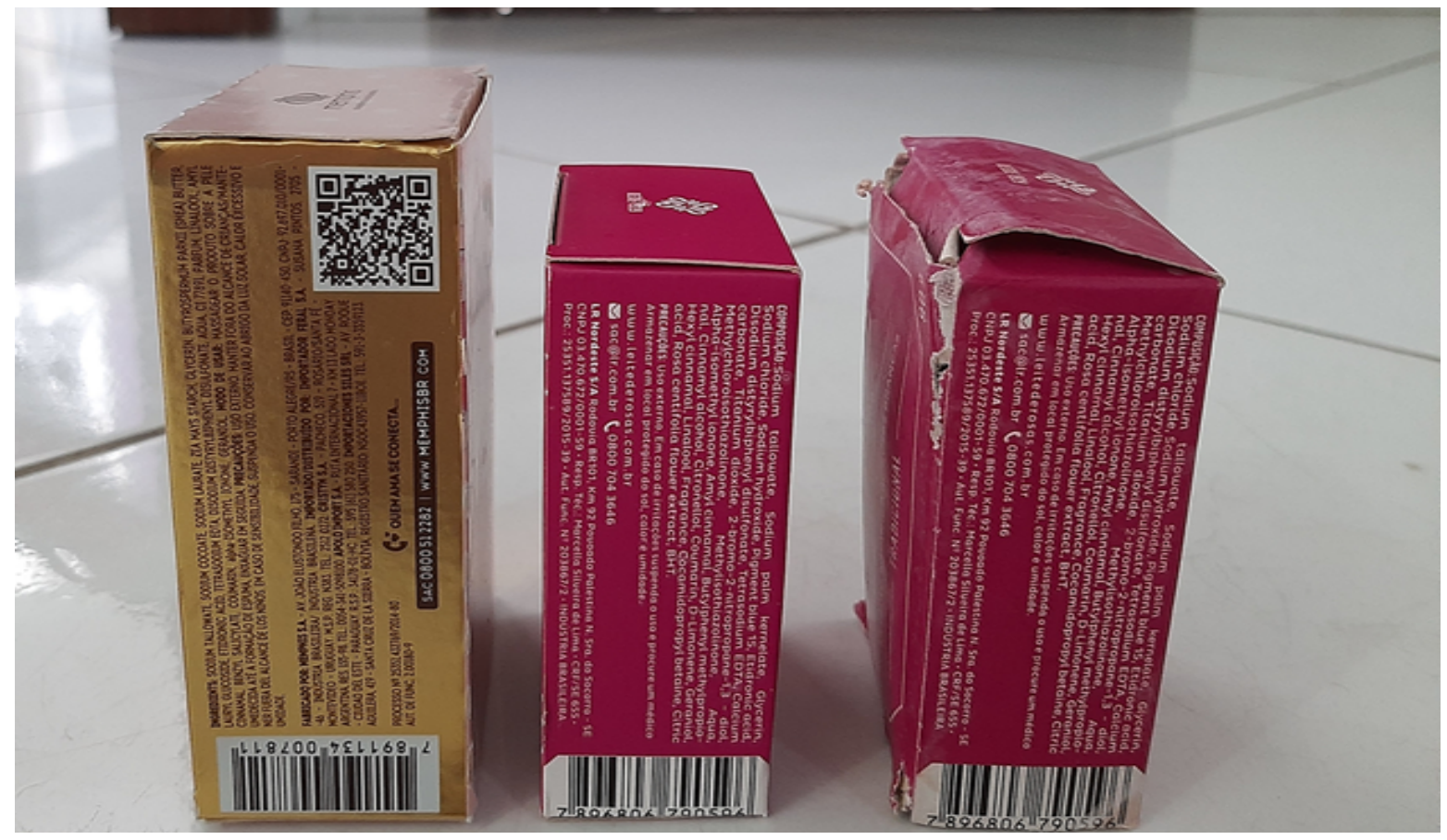

Fonte: Autora, 2021

(Observe que esses questionamentos levam aos estudos de áreas distintas como as da economia, da história, química, física, matemática, etc., de modo hibridizados. (SILVA, 2019). 
Abaixo apresento outros questionamentos que surgem a partir da pergunta 3.1

3.2 - Quais os produtos usados na fabricação das caixas?

(Essa pergunta direciona-se os estudos dos elementos químicos)

3.3- É possível fazer a reciclagem das caixas? Como fazer essa reciclagem?

(Essa pergunta direciona-se aos estudos das ciências naturais e do tema transversal sobre meio ambiente; ética e cidadania, pluralidade cultural. (SILVA, 2016).

3.4 - Quais objetos podem caber na caixa? Por quê?

(A pergunta caminha para o campo de estudo da matemática)

Dependendo das respostas dos alunos, se for dito por eles, por exemplo, que depende do comprimento e da altura do objeto com relação ao tamanho da caixa. Então, pode-se fazer os seguintes questionamentos:

Figura 34 - Medição da caixa

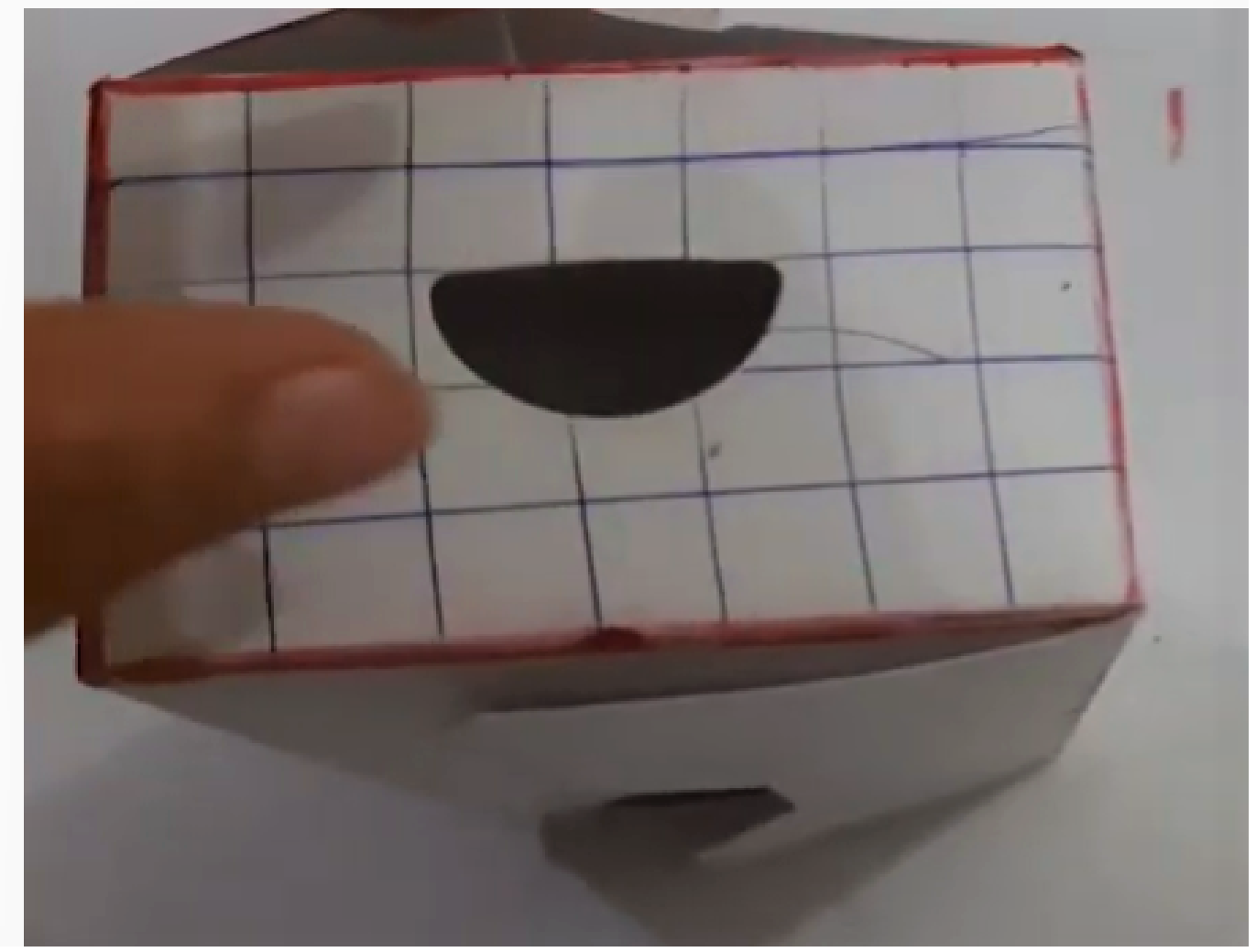

Fonte: https://www.youtube.com/watch?v=C5FDezWCZh8 
3.5 - Como definir comprimento e altura da caixa?

Dependendo da resposta dos alunos, se por exemplo, comentarem sobre medir a caixa usando uma régua para encontrar esses elementos, então questione:

3.5.1- Por que para encontrar comprimento e altura é necessário usar as medidas padronizadas?

3.5.2 - Pode-se usar o palmo para construir a ideia de comprimento e altura da caixa? Comprimento e altura são construídos? Qual a intenção?

3.5.3 - É preciso de que elementos para se construir casas, terrenos, caixas e outras coisas?

3.6 - Cada objeto construído é feito em um mesmo lugar ou cada um ocupa lugares diferentes? Por quê?

(Essa pergunta caminha para o campo da geografia, física, engenharia)

3.7 - Depende de que elementos essa ocupação em lugares diferentes por cada uma das coisas construída em nossa sociedade?

3.8 - Depende da área, do perímetro?

3.9- Como definir área e perímetro, por exemplo, da caixa? 
Figura 35 - Recortes da caixa de embalagem diversas em unidades menores

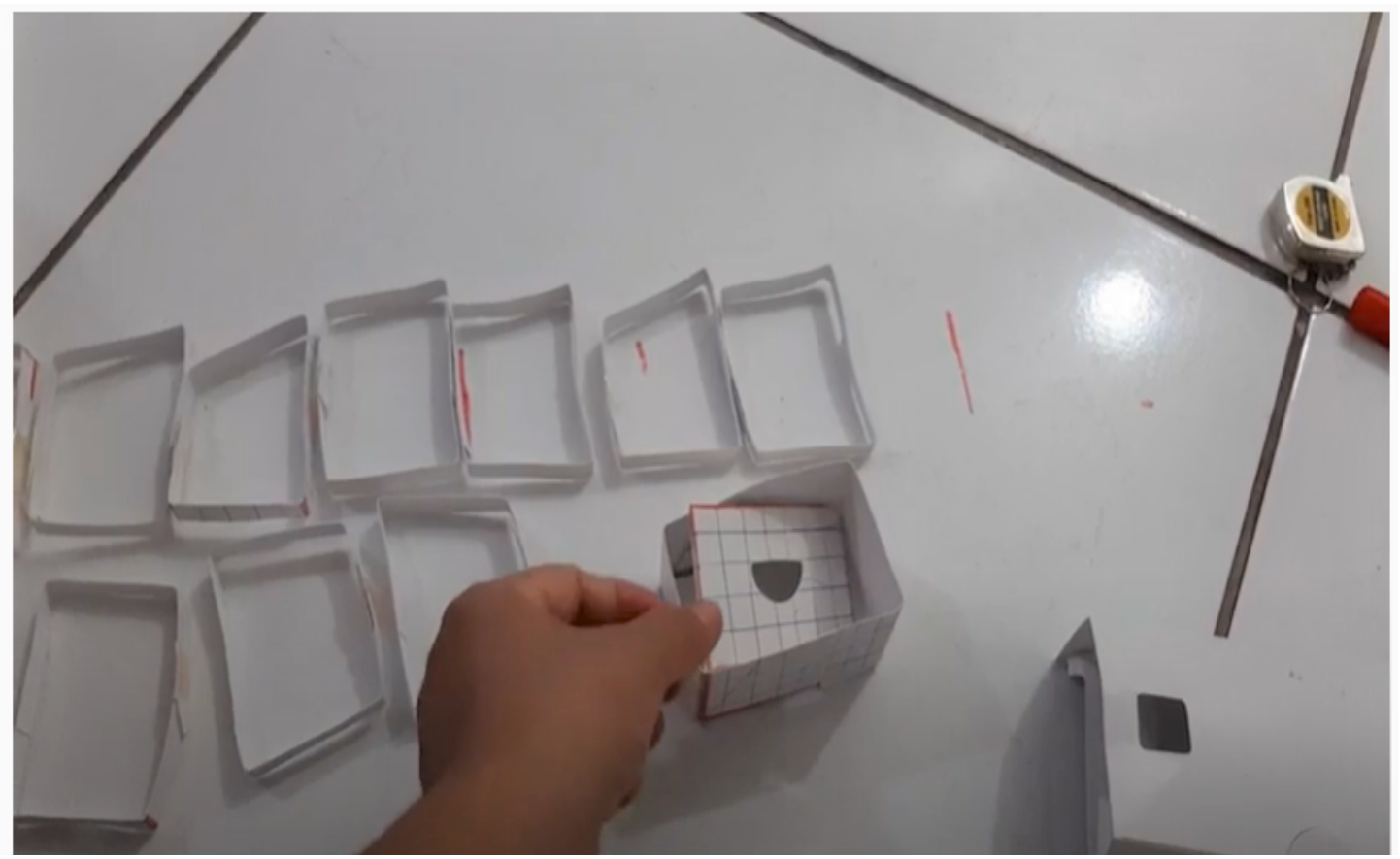

Fonte: https://www.youtube.com/watch?v=C5FDezWCZh8

3.10 - É possível recortar a caixa em unidades menores? Como se faz isso?

(Desconstrução da caixa, isto é, estudo da técnica, dado na $2^{a}$ fase da EDR)

3.11 - O tamanho da caixa depende do volume do objeto?

3.12 - Como definir volume dessa caixa?

3.13 - O que são as áreas laterais e total da caixa? Como defini-las?

3.14 - Com que figura geométrica a caixa se parece? Por quê?

3.15 - Como definir uma figura geométrica?

\section{Questões de matemática para $07^{\circ}, 8^{\circ}, 9^{\circ}$ anos}

(Aqui chegamos na execução da nova tarefa, a construção da ideia de paralelepípedo, cubo, prisma, que vai depender da forma da caixa que o aluno irá trazer para a sala de aula, ocorrido na $3 .^{a}$ fase da EDR, sendo a execução da nova tarefa, por meio da combinação de estudos de áreas distintas, no sentido da matemática mista.

\section{Acesse o meu canal no Youtube:}

https://www.youtube.com/watch?v=C5FDezWCZh8 


\section{ALGUMAS CONSIDERAÇÕES}

As práticas do campo, não somente elas, quando ensinadas na escola possibilitam o funcionamento dos saberes escolares, por meio do desmonte e remonte dessas práticas, conforme foi mostrado nos modelos de tarefas envolvendo a construção do manual textualizado de como se faz um matapi; os poemas sobre esse instrumento, o problema do terreno, as caixas de embalagens diversas, isso fez com que o percurso caminhe da comunidade para a escola, e após desenvolver estudos sobre sua melhoria retorna à comunidade, o que mostra a engenharia didática realizando um percurso reverso, estudando essas práticas pelo processo da desconstrução e reconstrução, que são conceitos advindos da engenharia reversa, daí ser denominada de EDR.

Com isso, mostramos pela EDR que uma prática do campo ao ser desconstruída, leva em conta seu desenvolvimento passado cristalizado na atualidade, para em seguida ser reconstruída, dotando-a de praxeologias intermediárias que vivem nas disciplinas escolares, com a riqueza de integrações de saberes, práticos e escolares, que possam eliminar dificuldades e potencializar o alcance dessas práxis quando reconstruída.

Enfim, a EDR por ser caracterizar como um tipo especifico de Percurso de Estudos e Pesquisa PEP (SILVA, 2019) voltado para a formação de professores do campo e ao mesmo tempo usada como um método de ensino, foi eficaz e eficiente, pois houve hibridização de saberes culturais com os escolares em uma dinâmica de reconstrução de saberes, através da transposição didática, que permitiu o questionamento e problematização. 


\section{REFERENCIAS}

Araújo, Maria Vera Ferreira de et. al. (2014). Pesca e procedimentos de captura do camarão-da-Amazônia. Biota amazônia. Macapá, v.4(2). p. 102-112. http:// periodicos.unifap.br/index.php/biota.

BRASIL. Base Nacional Comum Curricular -BNCC. 2018. Disponível em: http:// basenacionalcomum.mec.gov.br/. Acesso em: 10 de novembro de 2020

CHEVALLARD, Yves; BOSCH, Marianna; GASCÓN, Josep. Estudiar matemáticas El eslabón perdido entre la enseñanza y el aprendizaje - ICE - HORSORI Universitat de Barcelona. Barcelona: Enero. 1997.

CHEVALLARD, Yves. A análise das práticas na teoria antropológica da didactico1 de ensino. Recherches em Didactique des mathématiques, v. 19, n. 2, p. 221266, 1999.

CHEVALLARD, Yves. La transposição didática. 3 ed. Buenos Aires: Aique grupo, 2009a

CHEVALLARD, Yves. La TAD faces au professeur de mathématiques. Toulouse. 2009b.

CHEVALLARD, Yves. La notion d'ingénierie didactique, un concept à refonder. Questionnement et élémentos de réponses à partir de la TAD. in Margolinas et al.(org.) : En amont et en aval des ingénieries didactiques, $\mathrm{XV}^{\mathrm{a}}$ École d'Été de Didactique des Mathématiques - Clermont-Ferrand (Puy-de-Dôme). Recherches em Didactique des Mathématiques. Grenoble: La Pensée Sauvage, v. 1, p. 81-108, 2009c.

CHEVALLARD, Yves. La Matemática en la escuela: Por una revolución epistemológica y didáctica. $1^{\mathrm{a}}$ ed.Buenos Aires: Libros del Zorzal, 2013d.

D' AMBROSIO, U. Sociedade, cultura, matemática e seu ensino - Educação e Pesquisa. São Paulo, v. 31, n. 1, p. 99-120, jan. /abr. 2005.Universidade Estadual de Campinas.

COSTA, Danilo Acatauassú da Silva et. al. Seletividade do matapi nas capturas de Macrobrachium amazonicum no baixo /rio Tocantins, Amazônia, Brasil. Bol. Inst. Pesca, São Paulo, v. 42, n.2, p. 403-417. 2016. https://www.pesca.agricultura.sp.gov.br/42_2_10BIP-1194p403-417.pdf. 
FARIAS, Guilherme. Engenharia reversa. Guiky [site]. 2009. Disponível em: http://www.guiky.com.br/2009/09/engenharia-reversa.html.

MORAES, Sergio Cardoso de. Saberes da pesca: uma arqueologia da ciência da tradição. Natal. 2005. Disponível em: http://ftp.ufrn.br/pub/biblioteca/ext/bdtd/ SergioCM.pdf.

MENDES, I. A. FARIAS, C. A. Práticas socioculturais e educação matemática. 1.ed. São Paulo: Editora Livraria da Física, 2014. (Coleção contextos da ciência).

SODRÉ, Gleison De Jesus Marinho; GUERRA, Renato Borges. O ciclo investigativo de modelagem matemática. Educ. Matem. Pesq., São Paulo, v.20, n. 3, p. 239-262. 2018.

SODRÉ, Gleison De Jesus Marinho. Modelagem matemática escolar: uma organização praxeológica complexa.2019. 161f. Tese (doutorado em educação matemática) - Instituto de Educação e Matemática e Cientifica, Universidade Federal do Pará, Belém, 2019. Disponível em: file:///C:/Users/Home/Downloads/2019_\%20 TESE_\%20GLEISON_DE_JESUS.pdf. Acesso em: 18 fev. 2021.

SILVA, Renata Lourinho da. Engenharia didática reversa e o ensino de matemática na formação continuada de professores dos anos iniciais do ensino fundamental da educação do campo.2020. In: SANCHES JUNIOR, Sidney Lopes; SOUZA, Patrícia Ferreira Concato de; MIKUSKA, Márcia Ines Schabarum (org.). Ensino da matemática ressignificando o ensinar e o aprender na educação infantil e os anos iniciais do ensino fundamental. 1. ed. Curitiba, PR: Bagai, 2020.

SILVA, Renata Lourinho da. O percurso de estudos e investigação e a manifestação de habitus. 2020, capitulo do livro: Educação, pesquisa e produção do conhecimento: distintos enfoques e abordagens no cenário atual. CORREAA, Marcos Britto; ROSA DOMINGUEZ, Fabiane da; BAUTISTA NUÑEZ, Marcela (Org.). Rio de Janeiro: Dictio Brasil, 2020. 214-229p

SILVA, Renata Lourinho da. Engenharia didática reversa como um dispositivo de formação docente para a Educação do campo.2019. 300f. Tese (doutorado em educação matemática) - Instituto de Educação e Matemática e Cientifica, Universidade Federal do Pará, Belém, 2019

SILVA, R. L.; GUERRA, R. B. Engenharia didática reversa e o desenvolvimento da matemática mista usando o software GeoGebra na formação de professores para o campo. REMATEC, [S. I.], v. 16, n. 37, p. 26-45, 2021. DOI: 10.37084/REMATEC.1980-3141. 2021.n37. p26-45.id314. Disponível em: http://www.rematec. net.br/index.php/rematec/article/view/314. Acesso em: 27 jul. 2021. 


\section{SOBRE A AUTORA \\ RENATA LOURINHO DA SILVA}

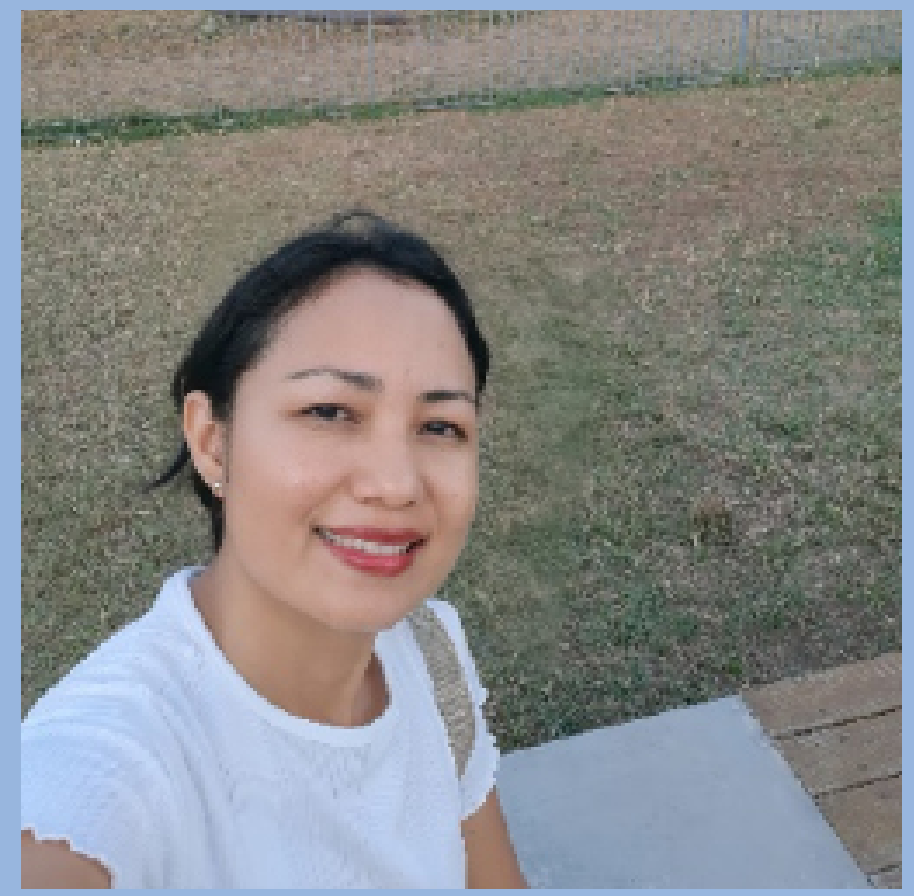

Doutora em Educação Matemática e Ciências pelo Instituto de Educação Matemática e Científica (IEMCI /UFPA). Mestra em Docência em Educação Matemática e Ciências, PPGEDOC-IEMCI-UFPA.È especialista em matemática do ensino básico e educação matemática e ciências para os anos iniciais do ensino fundamental, ambos pela Universidade Federal do Pará (UFPA)/Campus Universitário Tocantins (Cametá). È licenciada em matemática e pedagogia. É professora na Secretaria Municipal de educação de Cametá, atuando na escola de formação E-for. Vice coordenadora do grupo de estudos e pesquisas das práticas etnomatemáticas na Amazônia-GETNOMA|UFPA| Campus Abaetetuba e membro do grupo de estudos e pesquisas em didática da matemática-GEDIM $\mid$ IEMCI $\mid$ UFPA.

Apresenta as seguintes experiências: tutora nos cursos de licenciatura em matemática pela educação à distância-EAD/UFPA; professora formadora pelo Plano Nacional de Formação de Professores (PARFOR); professora substituta, horista e colaboradora. Já publicou artigos e capítulos de livros que envolvem as práticas de ensino para a educação do campo. 
www.arcoeditores.com

(6) contato@arcoeditores.com

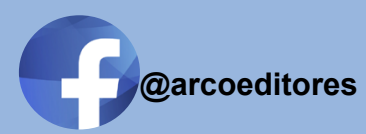

(C) Iarcoeditores

(55)99723-4952

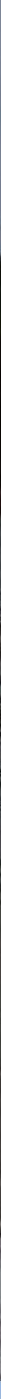

\section{$A \bar{C} C O$}

